Fall 11-21-2020

\title{
Reducing Catheter-Associated Urinary Tract Infection Project
}

\author{
Beatriz Agado \\ University of St. Augustine for Health Sciences, b.agado@usa.edu \\ DOI: https://doi.org/10.46409/sr.PVHX5973
}

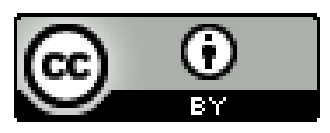

This work is licensed under a Creative Commons Attribution 4.0 License.

Follow this and additional works at: https://soar.usa.edu/scholprojects

Part of the Bacterial Infections and Mycoses Commons, Nursing Commons, Other Rehabilitation and Therapy Commons, and the Patient Safety Commons

\section{Recommended Citation}

Agado, B. (2020). Reducing Catheter-Associated Urinary Tract Infection Project. [Doctoral project, University of St Augustine for Health Sciences]. SOAR @ USA: Student Scholarly Projects Collection. https://doi.org/10.46409/sr.PVHX5973

This Scholarly Project is brought to you for free and open access by the Student Research at SOAR @ USA. It has been accepted for inclusion in Student Scholarly Projects by an authorized administrator of SOAR @ USA. For more information, please contact soar@usa.edu, erobinson@usa.edu. 


\title{
Reducing Catheter-Associated Urinary Tract Infection Project
}

\author{
Beatriz Agado, MSN, RN
}

School of Nursing, University of St. Augustine for Health Sciences

This Manuscript Partially Fulfills the Requirements for the

Doctor of Nursing Practice Program and is Approved by:

Dr. Debbie Conner, PhD, MSN, ANP/FNP-BC, FAANP

Dr. Norma Teran, DNP, MBA, RN

November 21, 2020 
University of St. Augustine for Health Sciences

DNP Scholarly Project

Signature Form

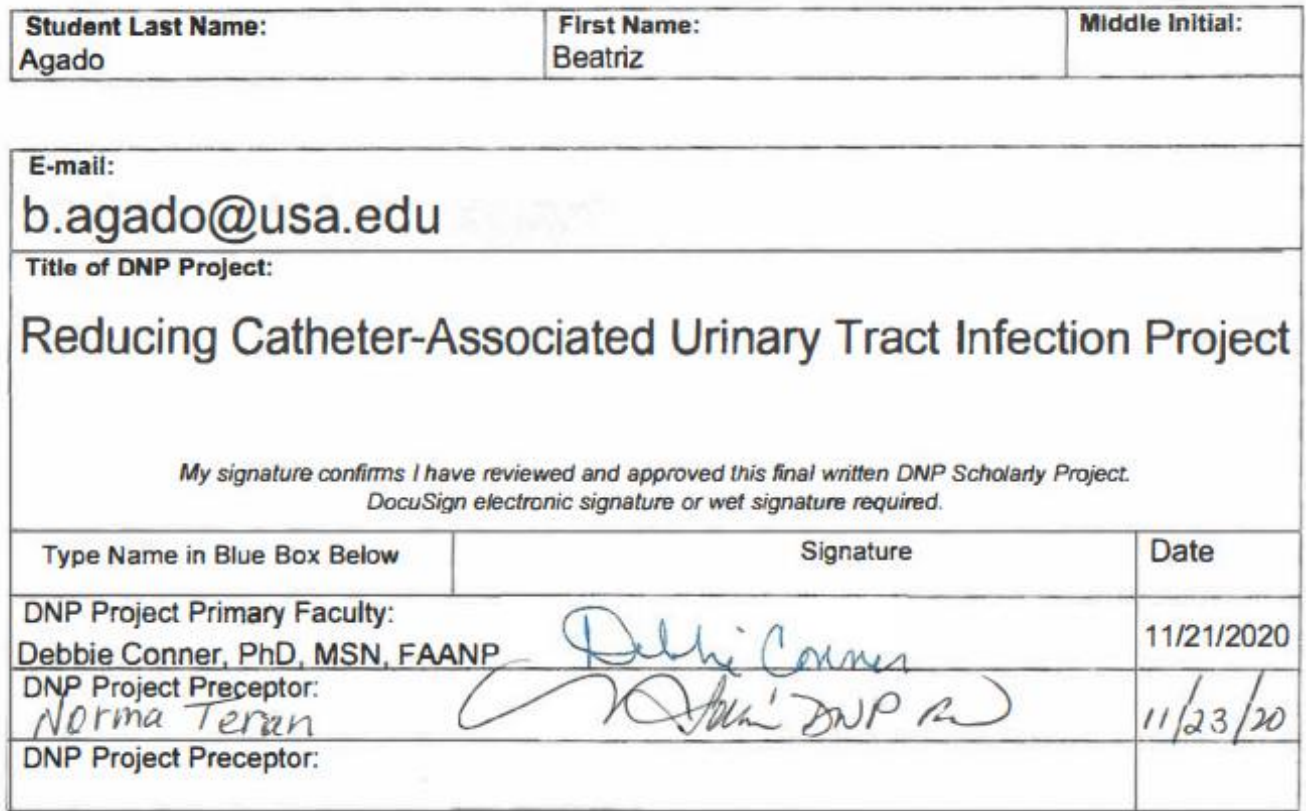




\begin{abstract}
Practice Problem: Catheter-associated urinary tract infections (CAUTIs) are prevalent and responsible for an estimated 13,000 deaths annually in the United States. Reported cases of CAUTIs remain disproportionately high at a rehabilitation center located in South Texas.

PICOT: This evidence-based project answered the following question: In rehabilitation patients, what is the effect of a nurse-driven protocol (NDP) CAUTI bundle on the number of indwelling urinary catheter-related infections, compared to the current practice, over a 12-week time period? Evidence: Twenty high-quality studies that met the inclusion and exclusion criteria recommended using an NDP CAUTI bundle, education, and champions to round the unit to decrease the number of catheter-associated urinary tract infections.

Intervention: The evidence-based intervention utilized the implementation of an NDP CAUTI bundle. The intervention bundle included catheter indication, hand hygiene, an insertion technique, maintenance, ongoing assessment to evaluate catheter need, and documentation.

Outcome: The evaluation of the outcome measures demonstrated that the CAUTI rate decreased from six incidences in 2019 to two from January to May 2020. There were zero incidences during the project implementation from June to August 2020, and the number of catheter days decreased from $59 \%$ at baseline to $41 \%$ post-intervention.
\end{abstract}

Conclusion: The implementation of a nurse-driven protocol CAUTI bundle, education, and champions in the unit were successful interventions that decreased the catheter-associated urinary tract infection rates in the rehabilitation center.

Keywords: catheter-associated urinary tract infections, nurse-driven protocol CAUTI bundle, quality improvement 


\section{Reducing Catheter-Associated Urinary Tract Infection Project}

Catheter-associated urinary tract infections (CAUTIs) are an essential part of the Center for Disease Control's (CDC) mission to prevent infections (CDC, 2019a). The complications of CAUTIs have created a high mortality rate (Makary \& Daniel, 2019a). Hospital-acquired infections (HAI) compromise the quality of patients' care. CAUTIs make up the largest percentage of HAIs, which lead to patient distress, increased healthcare costs, unnecessary antibiotic exposure, morbidity, and mortality (CDC, 2019a). Prolonged catheterization, failure to follow consistent sterile procedure, and the inadequate flow of urine often increases the cases of CAUTIs. Findings from numerous studies have documented a nurse-driven protocol (NDP) CAUTI bundle approach which reduced CAUTIs and adverse events (CDC, 2019a; Durant, 2017; Dy et al., 2016; Leticia-Kriegel et al., 2019; Quinn, 2015). Therefore, NDP CAUTI bundle intervention effectively decreased CAUTIs in rehabilitation patients.

The purpose of this evidence-based project (EBP) was to identify methods to decrease CAUTIs in hospitals by implementing best practice protocols with patients whose treatment involved indwelling urinary catheters. This paper includes discussions of the practice problem and its significance: population, intervention, comparison, outcome, and time (PICOT) question; a theoretical framework; synthesis of the literature; practice recommendations; and project settings. Furthermore, the paper outlines the mission, vision, project plan, evaluation plan, dissemination proposal, and project conclusion.

\section{Significance of the Practice Problem}

Patients can contract hospital-acquired infections (HAIs) when they receive medical treatment in a health care facility (CDC, 2019a). CAUTIs lead to the most diagnosed HAIs, accounting for $70 \%$ to $80 \%$ of all HAIs (Stacy, 2019). In the United States, an estimated 720,000 
CAUTI incidences occur annually, causing more than 13,000 deaths, which costs $\$ 340$ to $\$ 450$ million dollars each year (Zurmehly, 2018). According to the CDC (2019), CAUTIs expand the length of a hospital stay from two to four days. In Texas in 2019, the rate of CAUTIs was 0.712 , which was below the comparable data of one for the national level (CDC, 2019a). At the DHR in Edinburg, Texas, the number of CAUTI rates in 2019 was at 1.104 , nearly $10 \%$ higher than the national and state levels (DHR, 2019). This is not just a problem in the United States.

The World Health Organization (WHO) considers CAUTIs a serious public health concern because they increase morbidity, mortality, hospital stay associated with healthcare costs, and suffering for affected patients and families (Menegueti et al., 2019). Healthcare expenditures have been shown to be $\$ 2400$ per case due to CAUTIs and their associated complications (WHO, 2019). The clinical manifestations differ based on the severity of the disease (Mizerek \& Wolf, 2015). CAUTIs can bring prolonged and severe consequences. Many families have reported psychological stress from the disruption of their work and caregiving obligations (Mizerek \& Wolf, 2015). The families of patients who contracted CAUTIs experienced lack of employment, loss of income, increased personal financial costs, and emotional stress (Memegueti et al., 2019). CAUTIs results in higher social, administrative, financial, legal, and ethical risks for an organization if not addressed effectively and efficiently (Johnson, 2018). Nurses and healthcare workers have the ethical duty to promote health, prevent risks, and alleviate suffering (CDC, 2016).

\section{Scholarly Question}

In rehabilitation patients, what is the effect of a nurse-driven protocol CAUTI bundle on the number of indwelling urinary catheter-related infections, compared to the current practice, over a 12-week time period? 


\section{Population}

The focus group of this project was patients 18 years and older. All patients were admitted to the rehabilitation center at the DHR organization. These patients had an indwelling urinary catheter (IUC) for different diagnoses.

\section{Intervention}

According to the World Health Organizations (2020) and Meddings et al. (2019), prolonged catheter use increased the risk of contracting CAUTIs. A nurse-driven protocol using a prevention bundle decreased patients' chances of contracting CAUTIs (Meddings et al., 2019). Part of the protocol included catheter indication, hand hygiene, insertion techniques and catheter maintenance. The prevention bundle employed a flowchart that indicated when the catheter should remain in place and when it should be removed.

An additional part of the prevention bundle was the NDP CAUTI bundle prevention tool, which required proper hand hygiene before and after catheter insertion, and the maintenance of an aseptic technique. This included sterile supplies: gloves, drapes, sponges, and an antiseptic solution (Meddings et al., 2019; Parker et al., 2017; Taha et al., 2017). The CAUTI bundle compliance tool implemented a catheter maintenance checklist: keeping the collection bag below level of the bladder, frequently inspecting the tube for kinks, keeping the urine collection bag off the floor, and regularly emptying the urine collection bag (Meddings et al., 2019; Parker et al., 2017; Taha et al., 2017). Lastly, catheter removal required the registered nurse (RN) to complete an ongoing assessment and evaluation of catheter need (Meddings et al., 2019; Parker et al., 2017; Taha et al., 2017). 


\section{Comparison}

DHR (2019) reported an increase of CAUTIs throughout the hospital. According to the Centers for Medicare and Medicaid (CMS) "Hospital Compare” data, DHR (1.104) was scoring above the national (1) and state (0.712) levels for CAUTIs. The desired goal was to bring cases of CAUTIs in the hospital to zero. The facility did not have a standardized protocol to care for patients with indwelling catheters. The hospital's existing practice of addressing CAUTIs did not follow a standardized protocol. Further, the available research evidence demonstrated that the intervention bundle would have a positive impact on infections in the rehabilitation center.

\section{Outcome}

The desired outcome of this process-improvement project was to decrease cases of CAUTIs in DHR's rehabilitation center over the span of 12 weeks. The staff was educated about the NDP CAUTI bundle and their knowledge was measured using the pre- and posteducation/training tool. The staff used the CAUTI bundle compliance tool when caring for patients that had an IUC in place. During implementation of the NDP, staff compliance was tracked. Data collection was ongoing to assess the outcomes of the implementation of the intervention. The implementation of the NDP CAUTI bundle in rehabilitation patients reduced the incidences of CAUTIs to zero during the project change; June to August 2020.

\section{Timeframe}

The project took place over a period of 12 weeks at the rehabilitation center at DHR hospital. Implementation of the NDP CAUTI bundle intervention began right after the University Evidence-Based Practice Review Council (EPRC) and the facility's Institutional Review Board (IRB) approved the DNP scholarly project. 


\section{Evidence-Based Framework and Change Theory}

A theoretical framework is valuable in an evidence-based project (EBP) because it increases the possibility of implemented interventions being effective, sustainable, and accessible (Dogherty et al., 2016). It is no longer the norm to rely solely on traditional or personal experiences when providing healthcare to patients (Dogherty et al., 2016). Instead, EBP investigated data to facilitate, promote, and guide healthcare providers when making healthcare decisions for patients (Dogherty et al., 2016). A framework and change model guided this EBP project.

\section{Evidence Based Framework}

The Plan-Do-Study-Act (PDSA) is a framework that can be used in evidence-based projects to quickly identify and correct weaknesses (Thomas, 2016). The PDSA framework was selected to guide this DNP scholarly project to decrease incidences of CAUTIs in the rehabilitation center. The framework's first phase is the "Plan" step which was used to define the issue, current state, and recommend a change (Sylvia \& Terhaar, 2018). In this phase, an interdisciplinary team was formed, roles were identified, timelines were set, and measures were identified to successfully complete the project. In the "Do" step, the intervention was implemented, data was collected, and evaluated to determine the success of the project (Sylvia \& Terhaar, 2018). The "Study" step was used to determine if the intervention was successful or if rapid changes needed to be made (Sylvia \& Terhaar, 2018). After the intervention was implemented the team worked together to analyze the results and assess if the outcome measures were met. The final step was "Act," in which a determination was made to maintain the NDP CAUTI bundle or to develop a new process (Sylvia \& Terhaar, 2018). 


\section{Change Theory}

Lewin's change theory (1947) concepts guided this project in changing behavior to reduce or eliminate CAUTIs. Change regarding infection prevention is imminent in rapidly growing, highly competitive healthcare organizations. Lewin's change theory could help organizations change their methodologies, processes, and structures to deliver safe, high-quality care (Hussain et al., 2018).

According to Lewin (1947), change happens in three phases: unfreezing, change, and refreezing. An organization creates opportunities during the unfreezing stage to encourage those affected by the change to let go of the traditional, unsuccessful practices (Wojciechowski et al., 2016). During the unfreezing stage, people generally see for themselves the need for change, which provokes them to unfreeze. Healthcare workers, responsible for the change in practices, increase the driving factors to alter and reduce, or eliminate resistance and barriers (Wojciechowski et al., 2016). Transparency in sharing the rates of CAUTIs at the unit level helped employees acknowledge the problem (Wojciechowski et al., 2016).

The next stage of the theory, change, is when movement occurs (Wojciechowski et al., 2016). It focuses on planning and implementing new practices while influencing the thoughts and behaviors about change (Wojciechowski et al., 2016). Involving frontline employees, physicians and other healthcare providers in the planning and implementation process was instrumental in moving the transition forward (Wojciechowski et al., 2016). During this stage, the team had strong support from the administrators to implement the intervention. In this EBP, the staff was educated with mandatory training regarding the importance of decreasing or eliminating inappropriate use of the catheter, along with proper placement and discontinuance. 
In Lewin's theory, the final stage, re-freezing, leads to stabilization and assessment (Wojciechowski et al., 2016). Providing information to employees about the implementation of new CAUTI protocols and giving feedback opportunities during the evaluation helped solidify the change. In this EBP, the director and the supervisor rounded the unit and reviewed the electronic medical records to ensure that patients met the criteria required for needing a catheter. The director and the supervisor assigned a "champion" for each shift so that if the staff had any questions regarding the new process, the champion could guide the employee. The champion was also responsible for reporting all issues regarding IUCs (Hussain et al., 2018).

The project manager, director, and supervisor helped maintain and sustain the intervention by collecting data and evaluating the process. They informed the administration whether the intervention decreased or eliminated CAUTIs and if any re-design work was needed. They ensured the rehabilitation unit was following the standardized NDP CAUTI bundle. Lewin's change theory (1947) offered a platform for positive change within the organization. In this case, it was used to decrease CAUTIs, length of stay, and total healthcare costs while also improving patients' quality of care (Hussain et al., 2018).

\section{Evidence Search Strategy}

A thorough literature review was conducted to identify the evidence that supported the problem question. This review led to the scholarly question, in rehabilitation patients, how effective is a nurse-driven intervention bundle on minimizing indwelling urinary catheter-related infections over 12 weeks compared to the current practice?

A comprehensive electronic search was conducted using the Cumulative Index to Nursing and Allied Health Literature (CINAHL), Pro-Quest and PubMed. Keywords were combined using Boolean Operators to form relevant statements. The search terms were as follows: 
catheter-associated urinary tract infection (CAUTI) OR urinary tract infection (UTI) OR infection prevention OR indwelling catheters AND CAUTI bundle OR checklist OR protocols OR hospitals AND prevention of CAUTIs OR patients 18-years and older.

A total number of 12,787 articles were found. The CINAHL search resulted in 1,183 articles; PubMed produced 5,675 articles; and ProQuest produced 5,959 articles. After limiting the search to only include publications from 2015 to 2020 to integrate the most current best practices, 3,772 articles remained. Inclusion and exclusion criteria were applied to narrow down the search. These were the inclusion criteria: English language, peer-reviewed, and scholarly articles that contained an abstract. Furthermore, the exclusion criteria eliminated studies that focused on pediatrics and non-human test-subjects, thus reducing the number of articles to 542 . An inspection of the titles and abstracts helped to eliminate 254 articles that did not relate to the PICOT question. This reduced the number of articles to 288. The articles were manually sorted, and their full texts were reviewed. Additionally, eight duplicate articles were removed, along with editorials, periodicals, and commentaries. This left 20 articles, which were thereby included in this project.

\section{Evidence Search Results and Evaluation}

The 20 articles included in the EBP project identified the importance of implementing a NDP using a prevention bundle to decrease CAUTIs. Methods included limiting the use of IUCs, catheter indication, hand hygiene, insertion technique, catheter maintenance, and promptly removing unnecessary IUCs. The Johns Hopkins Nursing Evidence-Based Practice (JHNEBP) appraisal tool was used to critically appraise the quality and strength of the 20 articles retrieved from the literature review (Schaffer et al., 2013). All 20 articles retrieved from the literature were rated as "A" or "B," which was considered high quality with enough evidence to support the 
intervention to decrease CAUTIs. Lastly, web sites from the American Nurses Association (ANA), Agency for Healthcare Research and Quality (AHRQ, 2015b), and the Center for Disease Control (CDC) were also referenced and included in the paper. A summary of the primary articles reviewed can be found in Appendix A, and a systematic review can be found in Appendix B.

\section{Themes from the Evidence}

Synthesis of the literature reviewed findings identified strategies that were credible and consistent with EBP to decrease CAUTIs. Themes included CAUTI bundle, NDP, staff education, and integration of technology. Furthermore, the American Nurses Association (ANA) CAUTI Prevention Tool was identified as a guide for the NDP (ANA, 2017). The use of CDC and AHRQ guidelines for CAUTI prevention was a secondary theme.

\section{Catheter-Associated Urinary Tract Infection Bundle}

One of the most effective interventions found in multiple high-quality level studies was the CAUTI bundle (Andrioli et al., 2016; Taha et al., 2017; Zurmehyly, 2017). The CAUTI bundle has been implemented in multiple acute care hospitals, long-term care facilities and rehabilitation centers. It has been proven to decrease CAUTIs in all kinds of medical facilities and services (Hur et al., 2019; Parker et al., 2017; Zurmehyly, 2017). The CAUTI bundle includes checklists, diagrams, and reminders with acceptable clinical indications to insert an IUC (Carr et al., 2016; Taha et al., 2017; Zurmehyly, 2017). It also implements competency checks of catheter insertion, aseptic technique, documentation, maintenance, continuous surveillance for the need of the catheters, and catheter removal (Andrioli et al., 2016; Furtado et al., 2016; Schreiber et al., 2018; Teha et al., 2017; Zurmehyly, 2017). Taha et al. (2017) demonstrated that implementing the CAUTI bundle decreased catheter use and that early removal of the catheter 
reduced CAUTI rates. Giles et al. (2015) and Meddings et al. (2017) concurred that implementation of the CAUTI bundle increased awareness of patients with IUCs in place, prompting staff to assess whether the IUC was still needed. Hur et al. (2019) stated that the bundle's implementation identified that $30 \%$ of the patients with IUCs did not meet the criteria for the IUC. Based on this evidence, significant confirmation shows that an NDP using a CAUTI prevention bundle can decrease HAI in patients.

The AHRQ (2015b) recommended that healthcare providers avoid the use of catheters as much as possible, prompt removal, surveillance, and awareness. These AHRQ (2015b) recommendations, found in many studies, demonstrated a decrease in CAUTI rates (Andrioli et al., 2016; Taha et al., 2017; Zurmehyly, 2017). The NDP CAUTI bundle in this DNP project incorporated five specific actions: nurse-driven protocol, staff education, integration of information technology, American Nurses Association CAUTI Prevention Tool, and guidelines for CAUTI prevention.

\section{Nurse-Driven Protocol}

In addition to the CAUTI bundle, the NDP helped decrease CAUTI rates system-wide (Durant, 2017; Dy et al., 2016; Leticia-Kriegel et al., 2019; Quinn, 2015). Quinn (2015) reported implementation of the NDP CAUTI significantly decreased infection incidence rates. Dy et al. (2016), concurred that the implementation of an NDP for early removal of catheters significantly reduced CAUTI rates. The results demonstrated a direct connection between the use of an NDP, catheters, dwell time, and rates of CAUTI (Quinn, 2015). Leticia-Kriegel et al. (2019) agreed that the implementation of an NDP could empower nurses to be active advocates for patients who have an IUC in place, and to remove catheters promptly when patients did not meet criteria. 
A group of experts created the ANA CAUTI Prevention Tool, which guides nurses' protocols and supports their effort to reduce CAUTIs (ANA, 2017). The tool kit's goals are to empower the nurses to remove catheters promptly and continuously evaluate patients with IUCs. The ANA CAUTI Prevention Tool pushed nurses to develop checklists and diagrams with the proper indications to insert a catheter (ANA, 2017).

\section{Staff Education}

Studies demonstrated the importance of education in CAUTI prevention. Li et al. (2018) examined a hospital-wide implementation CAUTI prevention bundle. Before project implementation, education was provided for staff, reminder signs were placed in patients' rooms, and checklists were used. On site study representatives provided answers to questions, while monitoring, and evaluating compliance to the intervention. CAUTI rates decreased with the implementation of the bundle. The study findings supported the need for education and monitoring (Li et al., 2018). Furthermore, two studies demonstrated how assigning a champion in each unit when implementing an EBP project could assist in the intervention's sustainability (Li et al., 2018; Underwood, 2015).

Education is an essential element of any process improvement initiative. However, monitoring and feedback are also important (Hernandez et al., 2019). Hernandez et al. (2019) used a daily urinary catheter maintenance checklist to assess if the CAUTI prevention bundle intervention was being effectively implemented. The ability to provide immediate constructive feedback enhanced practice and was an invaluable benefit of implementing the CAUTI prevention bundle. McCoy et al. (2017) determined that education on CAUTI bundle promoted compliance with the newly established protocol, leading to reduced IUC use and CAUTIs to improve patient outcomes. 


\section{Integration of Information Technology}

Current technology offers health care practitioners various tools that could be used for the implementation and evaluation of EBP projects. Health information technology (HIT) has played a significant role in enhancing the quality of health care (Liu et al., 2018; McCoy et al., 2017). In New York, White Plains Hospital utilized HIT in its successful CAUTI prevention project to identify patients with IUCs (Quinn, 2015). Staff also used HIT to document the maintenance of IUCs (Quinn, 2015).

Several studies demonstrated that HIT was used successfully to collect and analyze patient demographics as well as to gather data on the incidences of urinary catheters and dwelling time (Carr et al., 2017; Dy et al., 2016; McCoy et al., 2017; Quinn, 2015). Information technology is critical in data collection for EBP projects because it keeps the project manager updated regarding the effectiveness of the implementation. HIT has many applications that can remind frontline staff to reassess patients with an IUC in place and to provide data on catheter utilization (McCoy et al., 2017; Quinn, 2015; Yatim et al., 2016).

\section{American Nurses Association CAUTI Prevention Tool}

In partnership with the CDC, the American Nurses Association (ANA) developed an EBP tool for nurses to use when caring for patients with an IUC in place (ANA, 2017). The tool intends to prevent CAUTIs by reducing the use of IUCs, prompting timely removal of catheters, and ensuring continuous evaluation when in use (ANA, 2017). The ANA (2017) CAUTI tool follows the CDC's recommendation (2017) for the insertion of an IUC. Indications include urinary retention, end-of-life care comfort, proper intake and output measurement in critically ill patients, certain surgical procedures, and immobilization in some patients, sacral ulcers, and 
perineal wounds. The ANA (2017) indicated that patients who meet the criteria for an IUC should be continuously assessed for the appropriate indication of the catheter.

\section{Guidelines for CAUTI Prevention}

In 2017, the CDC updated its 2009 guidelines for CAUTI prevention to reflect new scientific findings and offered recommendations for the use, measurement, and monitoring of IUCs (CDC, 2017b). The CDC (2017b) guidelines recommend that IUCs should only be used with certain patients including; patients with obstruction of the bladder outlet; for the intake and output of critically ill patients; designated perioperative patients; patients with open sacral or perineal wounds; patients with long periods of immobilization, such as those with some neurological conditions; and patients with end-of-life comfort needs (CDC, 2017b). The guidelines discourage the use of IUC in patients whose conditions are outside of the indicated categories (CDC, 2017b).

In 2015, the AHRQ published CAUTI prevention guidelines for healthcare providers. The main recommendations for healthcare providers include catheter avoidance, product selection and care, prompt removal, surveillance, and awareness. The AHRQ guidelines were similar to the ANA and the CDC recommendations, with more suggestions for robust unit-based safety programs (AHRQ, 2015b). The CDC (2017b) recommended that an IUC be inserted by qualified and competent clinicians and use an aseptic technique and sterile equipment for patients identified under the indicated criteria. The catheter should remain sealed, and the patient's urine flow should be unobstructed. Qualified professionals, who should be mindful of avoiding infections, should maintain the catheters. The catheter should be removed as soon as the indication for use is no longer appropriate (CDC, 2017b). 


\section{Practice Recommendations}

The reviewed articles answered the PICOT question by providing evidence that the implementation of a CAUTI bundle reduced CAUTIs, particularly among elderly and high-risk patients. Results and themes from the evidence can be found in the grading tables (see Appendices A and B). The evidence and themes strongly recommended a NDP using a CAUTI bundle to effectively reduce CAUTIs, hospital days and cost. High quality Level 1 and Level 2 articles had profound similarities, and themes, denoting that the NDP CAUTI bundle approach would reduce CAUTI rates (Fonseca \& Veludo, 2016; Galiczewski \& Shurpin, 2016; Hernandez et al., 2019; Smith, 2015; Parker et al, 2017).

Another recommendation was staff education. Evidence demonstrated that employee education supported best practice and sustainability. Education awareness programs and regular rounding by the champions, the director, and the supervisor helped reduce incidences of CAUTIs (Galiczewski \& Shurpin, 2016; Hernandez et al., 2019; Parker et al, 2017).

Several studies took place in acute care hospitals across the United States using the CDC, the ANA CAUTI prevention toolkit, and AHRQ guidelines. All hospitals reported a significant reduction in CAUTI rates after intervention of the protocol (Hernandez et al., 2019; McCoy et al, 2017; Parker et al, 2017). After a thorough literature review, it was concluded that the evidence supported a comprehensive practice recommendation. Therefore, a nurse-driven protocol CAUTI bundle was recommended for practice. The evidence consisted of Level 1 and grade A articles of high quality, validity, and reliability. The recommendation to implement a NDP CAUTI bundle was presented to the key stakeholders at DHR and to the USAHS EPRC. 


\section{Project Setting}

The DNP scholarly project setting was the rehabilitation center of a 530-bed acute care hospital in Edinburg, Texas. The hospital provided a full range of medical services, with more than 60 specialties and sub-specialties (DHR, n.d.). The mission of DHR (n.d.) was to enhance the well-being of those they served with a commitment to excellence for each patient, each experience, and each time. The organization's vision was to inspire caregivers to heal through empathy, experience, creativity, integrated treatment, and excellence (DHR, n.d.).

The rehabilitation center treated a variety of acute care needs, including amputations, brain injuries, major multiple traumas, neurological disorders, orthopedics post-operative, spinal cord injuries, and stroke-related disabilities. In the 38-bed rehabilitation center, a team of highly trained physicians, therapists, nurses, and ancillary staff served patients. The rehabilitation's primary goal was to help the patients return to their highest possible level of independence and functioning after a life-altering injury or illness (DHR, n.d.). Specific information about DHR was reviewed below, including the organizational structure, culture, needs, stakeholders, sustainability, interprofessional collaboration, strengths, weaknesses, opportunities, and threats analysis.

\section{Organizational Structure}

The DHR Healthcare System was one of the largest physician-owned facilities in the United States (DHR, n.d.). The organization included multiple units, such as outpatient rehabilitation, long-term care, urgent care centers, psychiatric services, women's services, bariatric services, and hospice (DHR, n.d.). Its organizational structure was composed of the chief executive officer (CEO), the chief finance officer (CFO), chief nursing officer (CNO), and 
its board of directors. The DHR healthcare system's daily operations were managed and controlled by the board of directors.

\section{Organizational Culture}

Employees were empowered to provide the highest and safest level of care through compassion, knowledge, innovation, integrated care, and excellence (DHR, n.d.). The organizational culture provided education and training to all staff members to improve their competency with the goals of delivering the best healthcare possible and increasing productivity. Staff members were diverse and included people from different educational backgrounds. DHR promoted education by offering its employees scholarships and provided staff incentives to motivate and retain experienced employees (DHR, n.d.).

\section{Organizational Need}

An organizational needs assessment identified an increase in CAUTIs throughout the organization since 2019, a statistically higher rate than the national average (DHR, n.d.). The fishbone tool was used to identify why there was a lack of interventions to reduce CAUTIs (Institute for Health Improvement (IHI), 2020). The results of the fishbone demonstrated that there was a lack of organizational awareness, and of staff knowledge regarding CAUTI interventions. The needs-assessment tool (IHI, 2020) was essential in developing ongoing EBP change. The tool helped identify gaps in hospital procedures that led to high infection rates. It was found that there was a knowledge deficit among facility staff that needed to be addressed to decrease HAI throughout the organization. The organization administration supported efforts to reduce or eliminate CAUTIs. A gap analysis (IHI, 2020) determined the need to establish a CAUTI bundle protocol to address the issue. The assessment also identified the need to educate 
staff about the importance of continuously assessing patients with IUCs and promptly removing catheters as indicated.

\section{Organizational Support and Stakeholders}

The stakeholders, particularly DHR's leadership, expressed a need to reduce incidences of CAUTIs. The key stakeholders identified for this scholarly project were the director of the rehabilitation center for departmental decisions, the $\mathrm{CNO}$ for authority, the nurse manager to supervise staff compliance, front line nurses to carry out the intervention, and the education department to develop trainings. Other stakeholders included physical therapists, doctors, advanced nurse practitioners, and physician assistants.

\section{Sustainability}

Sustainability allows for an EBP project to continue delivering improved results to patients, staff, and the organization (Li et al., 2018; Underwood, 2015). One of the most important concerns was to ensure employees' compliance with the NDP CAUTI bundle. This was tracked by assigning a champion on the floor to monitor staff. Another key factor for the sustainability of this project was continuous education on the CAUTI bundle protocol. New hires received orientation and education about the new CAUTI bundle protocol (McCoy et al., 2017).

\section{Interprofessional Collaboration}

Interprofessional collaboration was an essential factor in the success of this scholarly project (Reisinger et al., 2017). To effectively implement the CAUTI bundle protocol and have positive results, the interprofessional team had to work together towards the same goal of decreasing CAUTIs. The frontline nurses were responsible for carrying out the intervention. The nurse manager was responsible for monitoring staff compliance. The infection control disease team was responsible for answering questions pertaining to the interventions and determining the 
possible causes of infection. The doctor, advanced nurse practitioner, and physician assistant were available to address any doubts clinical staff had while discontinuing catheters. The education department was responsible for providing training to staff members.

\section{Strengths, Weaknesses, Opportunities, and Threats Analysis}

The strengths, weaknesses, opportunities, and threats (SWOT) analysis is a strategic planning tool used to help individuals or a company recognize their strengths, weaknesses, opportunities, and risks relevant to business or project planning completion (Gürel \& Tat, 2017). See Appendix E for the project's SWOT Analysis. The primary strength of the hospital was leadership members' dedication to decrease CAUTIs. Effective communication among staff, directors, nurse managers, and leaders helped facilitate the project's implementation. All needed resources to implement the project were available. The director of the rehabilitation center and the supervisor promoted the project. Another identified strength was that the organization had a strong education department that provided ongoing trainings to its staff. A recognized weakness was that frontline staff had busy schedules, which made it difficult to continuously assess the proper indication for the IUC. Opportunities identified were that CAUTI bundle protocol would reduce catheter days, hospital days, and the cost of treating patients with CAUTIs. These opportunities can ultimately improve patient outcomes and satisfaction (DHR, n.d.).

\section{Project Overview}

It was necessary to have the vision of the project clearly outlined to achieve the desired goal. The mission and objectives successfully guided the implementation of the project. The short and long-term goals were essential since they effectively guided the intervention to improve processes of mitigating infections in the hospital. 


\section{The Project Vision and Mission}

The project's mission, vision and objectives effectively conveyed the purpose of the project, kept the participants focused on the desired goal, helped the team stay on schedule, and maintained the intervention's sustainability. The mission of the project was to implement the NDP CAUTI bundle. The vision of the EBP process was to reduce or eliminate CAUTIs in the hospital. The mission and vision of the project were congruent to those of the organization because the purpose was to provide the best EBP to improve healthcare for patients. The objective of the project was to decrease the use of IUCs. The project's desired outcome was accomplished through short term and long-term goals. Achievement of the goals motivated staff compliance to carry out the intervention and sustaining the project.

\section{Objectives}

Objectives, short- term goals and long-term goals were the driving forces for this project to be successful. Short-term objectives of this project included: a) to implement an EBP NDP CAUTI bundle by June 2020; b) to improve frontline staff knowledge by $65 \%$ regarding the ANA CAUTI prevention tool during the first week of project implementation; and c) to decrease catheter days by $0.5 \%$ in the first three months of project implementation. The primary long-term objective was to disseminate the project into the community's acute care hospitals within one year of initial implementation. A second long-term goal was to spread beneficial findings of the project within three years through quality services and interactive webinars at a regional level.

\section{Risks and Unintended Consequences}

Strategies to address problems before they occurred can be developed by identifying risks (Advani \& Fakih, 2019). One risk was removing catheters prematurely, leading to the need to recatheterize. The re-insertion of a catheter can cause discomfort, trauma, and other potential 
complications for patients. It was crucial to assess carefully re-catheterizing avoid unnecessary patient harm (Mody et al., 2017). It was also imperative to provide the needed training to improve the competency level of staff to always maintain a patient-safety culture (Mody et al., 2017). Other possible risks included ineffective communication that could occur among the staff due to staffing issues, and resistance to change from frontline staff, impeding positive outcomes. The interprofessional team helped address resistance to change as early as possible to prevent delays and adverse project outcomes.

\section{Project Plan}

The project's plan included the selection of a model that guided the identification of barriers and facilitators. Lewin's change model was selected to guide the project since it relates to changing behavior, such as implementing processes that reduce or eliminate CAUTIs in an organization (Hussain et al., 2018). The PDSA model set a time frame for completing essential deadlines to ensure the project's timeliness (Sylvia \& Terhaar, 2018). The project plan also included a financial budget, which consisted of project expenditures and revenues (Sylvia \& Terhaar, 2018). The project manager's role required effective communication, transparency, and trust to achieve the project's goals successfully.

\section{Intervention}

The PDSA model was selected because it had been effective in implementing a rapid change in a rehabilitation center and demonstrated to be a useful and practical guide for implementing protocols throughout a hospital (Sylvia \& Terhaar, (2018). The initial stage, aligned with Lewin's unfreeze stage, began by creating a sense of urgency in reducing CAUTIs in the rehabilitation center (AHRQ, 2015a). The NDP CAUTI bundle was shared to promote interest and enthusiasm to bridge the gap between the existing and desired practice, while at the 
same time maintaining compliance with the state requirements and the Joint Commission guidelines (AHRQ, 2015a).

An interdisciplinary team was developed to openly discuss issues, concerns, ideas and possible factors for the success or failure of the project (Hussain et al., 2018). A charter plan was developed to establish roles, responsibilities, and an agreement for the project (Kogan et al., 2015). Creating a cohesive interprofessional partnership was a critical component of the project's success. First, a meeting was held with the interdisciplinary team to share the project's vision of reducing CAUTIs across the rehabilitation center. Afterward, a team was formed, roles were assigned, and responsibilities were given. The project had a strong support from leadership to implement the intervention (Hussain et al., 2018).

An in-depth assessment was conducted to assess weaknesses and threats that could interfere with the intervention (Kogan et al., 2015) and allow for a greater understanding of the microsystem (Gürel \& Tat, 2017). A fishbone diagram was displayed in the education room to collect feedback from rehabilitation staff (Kogan et al., 2015). This tool helped define staff needs, raised engagement, and increased buy-in. The results of the SWOT analysis and fishbone diagram were shared with and addressed by the team.

At that time, the rehabilitation center did not have a standardized IUC protocol. The intervention was an NDP CAUTI bundle that included: (a) appropriate indication for insertion of the catheter; (b) proper insertion technique; (c) proper catheter maintenance; (d) timely removal of the catheter; (e) effective documentation in the electronic medical record (EMR) and in the CAUTI bundle compliance tool; and (f) identification of a unit champion for every shift to monitor the staff for compliance to the protocol. The tool included all the key components of the 
CAUTI bundle and a checklist that prompted nurses to effectively document their actions (see Figure 2). It encouraged nurses to remove catheters when no longer needed.

During the Do stage of the PDSA Model, which aligned with Lewin's Change stage, the EBP project began with the education of the clinical staff regarding the NDP CAUTI bundle (Hussain, et al., 2018; Sylvia \& Terhaar, 2018). The training, which was conducted by the education department, included a pre- and post-education training competency check. The checks' results, which determined NDP CAUTI bundle's competency, were evaluated and shared with the team. To implement the CAUTI bundle, the supervisor identified the patients in the unit with an IUC and shared the information with the staff during the morning huddle. The supervisor then reinforced the need to assess the patients with IUCs for the appropriateness of the catheter (see Figure 1). The supervisor also encouraged and reiterated the need for documentation on the CAUTI bundle compliance tool. The assigned champion rounded the floor to support the staff regarding the newly implemented protocol.

Once the intervention was implemented, data was collected weekly to track the progression of the project. The data gathered included the total number of new CAUTI events in the rehabilitation center, the number of patients with catheters, and the number of catheter days. Other significant data collected were the total number of nurses who completed the NDP CAUTI bundle compliance tool, and the number of clinical staff who completed education and training.

The Study stage of the PDSA Model aligned with Lewin's re-freeze stage and guided the data's evaluation (Hussain, et al., 2018; Sylvia \& Terhaar, 2018). An Excel spread sheet was used to display the data collected through bar charts and running charts that were shared with the team. The pre-implementation data was compared to the post-implementation data to determine the intervention's effectiveness. 
The final step of the PDSA model was the Act stage (Sylvia \& Terhaar, 2018).

Summative and formative evaluations were completed by the DNP student to describe the results in more detail, which were then presented to the key stakeholders. The results determined if the objective of reducing CAUTIs in the rehabilitation center was met. The project's results indicated intervention sustainability. The project proved to be effective because the CAUTI incidences remained at zero after completion of the project. This was followed by disseminating the project across DHR's facility, community, regionally and nationally.

\section{Barriers and Facilitators}

There were barriers and facilitators when implementing this EBP project. The identification of some of these barriers before the project began played an essential role in its success. Some barriers included staffing issues (which made it difficult for employees to attend the trainings), clinical staff turnover, and staff non-compliance to the protocol. One way to facilitate some of the barriers was having the project manager perform ongoing assessments to address the barriers as soon as possible. Another way was assigning the champion and supervisor on the unit to ensure staff members were following the protocol. The director and supervisor of the rehabilitation center helped with the staffing issues that were presented. A very important facilitator was having leadership support to sustain the ongoing trainings needed throughout the project.

\section{Project Schedule}

Before implementation of the DNP scholarly project, approval from the EPRC from the University of St. Augustine for Health Sciences (USAHS) was obtained. Following the approval of USAHS, the project was submitted to the DHR IRB for consent. After obtaining approval, an interdisciplinary team was developed, education sessions were scheduled, a competency 
evaluation was completed, the frontline staff was ready, and all the resources needed were in place. This allowed for the implementation of the intervention to commence. The evaluation of the process was ongoing to determine if there was compliance with the intervention. Project implementation occurred over 12 weeks. A detailed project timeline is presented in Appendix C.

\section{Resources and Budget}

The interprofessional team's resources supported all areas of the project, training rooms and educational materials, such as handouts, flyers, posters, and signs to promote the NDP CAUTI bundle. The budget included training for twenty rehabilitation nurses at a rate of $\$ 33.00$ per hour. The training was two hours long, costing approximately $\$ 1,320$, with additional attendee snacks costing roughly $\$ 250$. The budget also included educational materials that cost about $\$ 450.00$. The total cost of the project was approximately $\$ 1,720$ (see Table 1).

\section{Project Management Role and Leadership Skills}

A project manager must possess strong leadership skills to lead the team to success and achieve desired goals (Ramazani \& Jergeas, 2015). The role of the project manager in this EBP project was to supervise and make important decisions. The project manager was also responsible for scheduling meetings, assigning tasks, setting deadlines and goals. Other responsibilities for the project manager were negotiating and mitigating the intricate nature of the numerous affected stakeholders (Ramazani \& Jergeas, 2015). Additional tasks of the project manager were to lead the team during the EBP project and to set the mission and vision, as well as to motivate and empower the team. The project manager also communicated the goals and progress of the project to everyone involved, with the additional goal of providing mentorship, inspiration, and building trusting relationships (Seidle et al., 2016). 


\section{Project Evaluation}

The evaluation plan had several purposes, including monitoring the success of the project and identifying problems (Thomas, 2016). Lewin's change model and the PDSA model guided the project evaluation (AHRQ, 2015 a; Hussain, et al., 2018). During the evaluation stage of this scholarly project, the CAUTI bundle compliance tool, the pre-and post-education/training tool, and the EMR facilitated the collection, analysis, and data measurement to evaluate the success of the NDP CAUTI bundle intervention.

\section{Selection of Participants}

The participants were patients in the rehabilitation unit with an IUC. Other participants were the clinical staff that assisted in the implementation of the NDP CAUTI bundle. Patients in the rehabilitation center who did not have an IUC and those from other medical units did not participate in the project.

\section{Protection of the Participants' Rights and Privacy}

The project involved continuous monitoring for ethical considerations, such as protecting participants' rights and maintaining privacy. The project proposal was submitted for approval to the University's EPRC and the facility's IRB Committee. To optimize compliance, the hospital's Ethics Committee reviewed the project. Previously set practices were enforced by the Health Insurance Portability \& Accountability Act regulations (HIPAA, 1996). The department used patients' medical record numbers and room numbers for identification purposes. A hard copy of the information was kept in a locked drawer in a locked office. Digital information was stored in an Excel spread sheet. No one was given access to it without the project manager's permission. 


\section{Data Details}

The data collected for this EBP project were used to measure the success of the project. The data included: (a) the total number of new CAUTI events in the rehabilitation center; (b) the total number of re-catheterizations; (c) the number of catheter days; (d) the total number of nurses who completed the NDP CAUTI bundle compliance tool; (e) the number of clinical staff who completed education and training; (f) patient satisfaction; and (g) staff satisfaction. The description of each measure was included in the "Categories of Measures" section.

\section{Variables}

This project's independent variable was implementing the NDP CAUTI bundle, which positively affected the rehabilitation unit. The compliance clinical of staff with the protocol was a dependent variable, with $76 \%$ demonstrated compliance. The CAUTI incidences stayed at zero, which was a positive outcome. The project outcome evaluation results confirmed that the intervention was effective.

\section{Validity, Reliability, and Data Sources}

It is essential that reviewers consistently measure data when assigning a value to a variable (Calderon et al., 2015). The project manager, director, supervisor, quality management (QM) registered nurse and infection control nurse were responsible for collecting data daily and applied reliable methods to verify the findings. Databases were managed and protected by the IT department. For example, the database Cerner required staff members to change their password every 90 days to maintain security (DHR, 2019). The project manager, director, supervisor, QM nurse, and the infection control nurse audited charts in the EMR. They oversaw the measuring, collected the data separately, and compared their findings. Any disagreements were discussed and mutually resolved. 
Data collection tools and surveys used in this DNP scholarly project were reliable tools commonly used in healthcare to improve practice. The tools and surveys have been utilized in several EBP projects across the healthcare systems, generating consistent and accurate results to improve processes (Galiczewski \& Shurpin, 2016; Hernandez et al., 2019; McCoy et al., 2017; Parker et al., 2017). The tools used for this EBP project were available for use as long as there was an acknowledgment of the source (Durant, 2017; Dy et al., 2016; Leticia-Kriegel et al., 2019; Quinn, 2015).

\section{Missing Data}

Missing data presents a significant and common challenge to the integrity of a project (Galliano, 2019). According to Galliano (2019), missing data in the project can cause erroneous results. The lack of information reduces statistical significance, can cause bias in the calculation of metrics, and reduces sample robustness. Since this was an EBP project, missing data could have complicated the evaluation of the study. Only the assigned team members collected, stored, and analyzed the data. No missing data were noted throughout the collection, storage, and analysis of the data.

\section{Evaluation Design}

The project evaluation design was quantitative. Pre- and post-intervention data were collected and compared to measure the project's success (Watson, 2015). The evaluation design of this EBP project generated substantive results related to the project's outcomes, best practice, and improved performance (Watson, 2015). The data provided the team with an overview of the project's success and what needed to be changed. 


\section{Categories of Measures}

Measures are a vital component of evaluating and implementing change. IHI (2020) claimed that measures were needed to keep the team informed of the implementation's progress. Five measures relevant to this EBP project were: outcome measures, process measures, balance measures, finance measures, and sustainability.

\section{Outcome Measures}

Outcome measures affect the healthcare system's clinical and financial well-being (IHI, 2020). The main goal was to decrease the incidences of CAUTIs in the rehabilitation center to zero. In 2019, the total number of CAUTIs was six. In 2020, from January through May, the total number of CAUTIs was two. From the beginning of the EBP project until its completion, June to August 2020, there were zero CAUTIs in the rehabilitation center. Another outcome goal was to decrease the catheter days. From June to August 2020, the catheter days decreased by $18 \%$. This indicated a significant improvement in the quality of care and reduced expenditures for the rehabilitation center and the organization.

\section{Process Measures}

Process measures are the specific steps in a project that can determine whether an intervention produces positive results (IHI, 2020). In this project's process measure, the goal was to achieve $65 \%$ compliance with the NDP CAUTI bundle by the end of the project. The result was $76 \%$ compliance, which was $11 \%$ higher than the benchmark. Another goal was to measure the efficacy of education and training. This was achieved by comparing the participants' pre- and post-education survey results. The $t$-value of 2.488 at alpha $=.05$, indicated a statistically significant difference between the participants' results of pre- and post-training. In summary, these two process measures demonstrated successful outcomes. 


\section{Balance Measures}

Balance measures required looking at the system from various directions and ensuring the occurring changes did not negatively affect other areas of the system (IHI, 2020). In this EBP project, the patient's satisfaction was measured to ensure that other areas of care were not neglected. This measure was completed using the Hospital Consumer Assessment of Healthcare Providers and Systems Survey (HCAHPS), and the QM nurse collected the data. The data produced from the survey were considered ordinal, since the data values followed a standard order (Li, 2016). Data were collected from June to August, and the overall patient satisfaction results had a weighted mean of 4.88 out of 5 , where 5 was the highest score possible. The results meant that the patients were satisfied with the overall care received in the rehabilitation unit. However, the survey did not specifically ask about the CAUTI bundle intervention. Further investigation in future projects would be required to determine the relationship between patient satisfaction and the NDP CAUTI bundle intervention.

\section{Finance Measures}

The finance measures' purposes were to monitor and control the organization's financial results or needs (Dobrzykowski et al., 2016). Financial measures determine the project's expenses and its returns. The finance measures included a weekly review of the financial status of the project to ensure budget compliance. The finance measures that were monitored were educating and training staff in the rehabilitation center, and the amount spent on one incidence of a CAUTI. During the training week, the facility was already conducting competency training; therefore, there was no additional money spent on project-related education. There was no money spent on CAUTIs as none occurred. According to the WHO (2019), the healthcare facility 
spends $\$ 2400$ per case due to CAUTIs and their associated complications. These results indicated that the facility saved money on the absence of CAUTI incidences.

\section{Sustainability Measures}

One measure to ensure the sustained use of the NDP CAUTI bundle was to incorporate the new protocol into the orientation for new recruits. Another method was giving the nurses a laminated pocket card with the NDP CAUTI bundle components as a reminder to use the tool. A final method was to integrate the NDP CAUTI bundle with the annual competency check-off list.

\section{Project Evaluation Results}

The project manager, to determine if the results of the project were significant, evaluated several areas. Descriptive statistics were calculated and analyzed to determine any statistical association between the pre-and post-intervention, new CAUTI incidences, and catheter days. The statistical analyses included calculations of frequency distribution, standard deviation, and change percentages. Several evaluation methods including formative, summative, and process evaluations were implemented.

\section{Outcome in PICOT Question}

The primary outcome measure and goal was to reduce the incidences of CAUTIs during the project period of June to August 2020. This was accomplished by following the NDP CAUTI bundle tool, ensuring nurse compliance in removing IUC as early as possible, and proactively preventing IUCs from being automatically inserted. In total, there were six CAUTIs in the rehabilitation center in 2019. There were only two from January to May 2020 and from June to August 2020, the incidences remained at zero. 


\section{Formative Evaluation}

The formative evaluation was used weekly to ensure the project was implemented as scheduled. The evaluation determined whether any changes needed to be made to improve the project's success (Scanlon et al., 2017). Several tools were used to evaluate the project's success, such as CAUTI bundle compliance tool, data warehouse, dashboard, EMR, and benchmarks. The formative evaluations were carried out by assessing the following measures: (a) the total number of new CAUTI events in the rehabilitation center; (b) re-catheterizations; (c) catheter days; (d) the total number of nurses who completed the NDP CAUTI bundle compliance tool; (e) the number of clinical staff who completed education and training; (f) balancing measures; and (g) financial measures. An evaluation of the project timeline was performed by the project manager weekly to promote timely completion of primary deliverables and determine whether any modifications needed to be made. Formative evaluations were used to advise and improve future processes (Scanlon et al., 2017).

\section{Summative Evaluations}

Although the information was compiled throughout the project, the summative evaluations were completed at the end of the project. The summative evaluations included analyzing the project's outcomes, findings, impacts of the intervention, and potential future implications (Nelson \& Staggers, 2018). The baseline average CAUTI rates were collected from the Hospital Compare website for the prior year of 2019. They were then compared to the results collected from the data warehouse and hospital dashboard (DHR, 2019). The data were presented to the team using graphs depicting a reduction of CAUTIs. The compliance of the staff to the protocol was measured by using the CAUTI bundle compliance tool. Compliance with the CAUTI bundle tool was $76 \%$ at the end of the project, which was $11 \%$ higher than the 
benchmark of $65 \%$. Patient and staff satisfaction were measured using HCAHPS and staff surveys. The patient satisfaction results demonstrated an overall weighted mean of 4.88 on a scale of 5, which meant patients were satisfied with care. The staff satisfaction survey results showed an overall weighted mean of 3.87 on a scale of 5 , which meant that more than half of the employees were satisfied with using the new intervention.

\section{Statistical Analysis}

The project included a collaborative effort with a statistician who assisted in analyzing and interpreting the data. The Statistical Package for Social Sciences (SPSS) software program, version 23, was used to analyze and compare the pre- and post-intervention data. The SPSS program was used to verify accuracy using a standard $p$ value $\leq .05$ to determine statistical significance of the newly implemented protocol effects. During the project, the primary data collected consisted of pre- and post-catheter days, a new number of CAUTIs, and recatheterizations. The primary data also contained the number of staff who effectively documented using the CAUTI bundle compliance tool. Secondary data included patient satisfaction and staff satisfaction ratings.

There were six incidences of CAUTIs in the rehabilitation center in 2019 and two from January to May 2020. Zero incidences of CAUTIs occurred during the project implementation from June to August 2020. These results were clinically significant in decreased length of stay and decreased healthcare expenditures (see Figure 1).

In the re-catheterization measure frequency and percentage, distribution was used to demonstrate significance in this outcome. In June, there were $5(38 \%)$ re-catheterized participants, $2(15 \%)$ in July, and $6(47 \%)$ in August. In July, the re-catheterizations decreased by $23 \%$ among patients with an IUC. In August, the re-catheterizations increased by $32 \%$ and 
did not improve in the last month during the DNP scholarly project implementation (see Figure 2). This area needs further investigation in future projects because re-catheterizations increase the risk for infections in patients with an IUC. It also merits further investigation because it increases pain and suffering in patients.

In the catheter days outcome measure, the frequency and percentage distribution were used to learn if the outcome measure was clinically and statistically significant. From March to May 2020, there were 396 (59\%) catheter days. From June to August 2020, there were 275 (41\%) catheter days during the implementation period, which meant catheter days decreased by $18 \%$. The results suggested that the intervention significantly decreased the catheter days (see Figure 3). When catheter days were reduced, the risk of patients developing an infection and staying in the rehabilitation longer than needed, decreased.

A paired $t$-test was used to compare pre- and post-staff education/training results. As seen in Table 2, there was a statistically significant difference between pre-( $\mathrm{M}=37.87, \mathrm{SD}=6.29)$ and post $(\mathrm{M}=41.63, \mathrm{SD}=5.76)$ results $t$-value of 2.488 at alpha $=.05$. As seen in Table 3,38 total admissions and 29 CAUTI bundle tools were completed. Therefore, the compliance was 76\%. The results of the descriptive statistics provided evidence of the nurses being compliant with the protocol.

In the staff satisfaction outcome measure, the staff survey had ten questions that had to be answered with "Strongly Agree," "Agree," "Neither," "Disagree," or "Strongly Disagree." The results demonstrated that an overall weighted mean was 3.87 on a scale of 5 , which meant that more than half of the staff supported the NDP CAUTI bundle. 


\section{Implications}

In this DNP scholarly project, implementing the NDP CAUTI bundle was clinically significant because it decreased CAUTI incidences and reduced catheter days in the rehabilitation center. The primary outcome was that CAUTIs decreased. Another relevant outcome measure was an $18 \%$ reduction of catheter days during the project implementation. These results reflected a substantial positive change, which occurred because unit nurses followed protocol and timely removed IUCs.

Before implementation of the project, the rehabilitation center did not have a standardized protocol to address patients who had an IUC in place. The NDP gave the nurses the autonomy to remove catheters in a timely manner, which decreased catheter days and ultimately reduced CAUTIs. Results supporting the effectiveness of the CAUTI bundle were consistent with the literature, which indicated that when catheters were removed early, the risk of CAUTIs

decreased (Durant, 2017; Dy et al., 2016; Leticia-Kriegel et al., 2019; Quinn, 2015). This project provided safer and improved care in the rehabilitation center.

One limitation of this project was its small sample size. Since COVID-19 caused the census to decrease in the rehabilitation unit, there were only 38 participants in this project. However, the project results demonstrated decreased CAUTIs and catheter days despite the small sample size, indicating the primary outcome measures' achievement. Another limitation related to COVID-19 was some of the nurses and CNAs were rotated to other departments, leaving the rehabilitation center short-staffed. This made it more difficult for the remaining staff to complete the CAUTI bundle tool.

Recommendations for the next steps involve integrating the practice change into new employee orientation and annual competency/training programs. It would also be beneficial to 
conduct the project in other departments and assess the outcomes. Implications of the process measures include suggestions to monitor staffing in the rehabilitation center closely. Maintaining adequate personnel would help nurses follow the NDP CAUTI bundle and help CNAs provide effective peri care.

There should be an ongoing evaluation of the protocol to maintain sustainability. Leaders of the rehabilitation center must review EMR to ensure the nurses are documenting the assessment on the patients that have an IUC in place to ensure appropriateness of the catheter. Frequently rounding the rehabilitation center would improve productivity and accountability for the prevention of CAUTIs.

\section{Plans for Dissemination}

Before disseminating the project results, analysis, and evaluation of the project's strengths and limitations, and potential for change, were required. The project was reviewed by the preceptor, rehabilitation director and supervisor, course professor, and university peers. Once feedback was collected, the project results were shared with the rehabilitation department staff during their monthly meeting and change of shift huddles. The results were presented verbally. In addition, flyers were made and given to the staff, and visual charts that depicted the department's previous and current status on CAUTIs.

The results of the project will be presented to the leaders of DHR during a quality improvement meeting. These leaders will include the chief medical officer, the CNO, and the directors of every department. The presentation will consist of verbal and visual descriptions of the project results. As approved by leadership, the results will be shared through a morning meeting, an email, an inter-facility newsletter, and during an infection control conference. The 
closing statement will discuss the availability of training material and additional resources to sustain the practice change.

The external dissemination to support the EBP intervention will include plans to share data with local hospitals, outpatient facilities, long-term care facilities, and nursing school programs through the local healthcare newsletter. The presentation will include project protocol, educational material, timelines, budget, and outcomes. Widespread dissemination will include sharing the results with the University of St. Augustine for Health Sciences. At the national level, project results will be presented at the American Nurses Association Conference. The author will seek publication of this project in the American Journal of Infection Control and the Journal of Urology. Lastly, this doctoral project will be submitted in full text for dissemination through SOAR, an electronic publication database supported by the USAHS.

\section{Conclusion}

The primary goal of the EBP project was to implement an intervention to reduce CAUTIs in DHR's rehabilitation center. CAUTIs are the leading cause of hospital-acquired infections. The literature reviewed identified that HAI is a preventable issue. It was found that the implementation of an NDP CAUTI bundle decreased CAUTIs. The project began with an organizational needs assessment conducted using the SWOT analysis tool. The organizational issue was identified as increased CAUTIs throughout the facility. Lewin's change theory and the PDSA model guided the change process for this EBP project. Consistent educational training and audits promoted the success and sustainability of the project. The expected outcome was to decrease the rate of CAUTIs to improve patient outcomes. 


\section{References}

Advani, S. D., \& Fakih, M. G. (2019). The evolution of catheter-associated urinary tract infection (CAUTI): Is it time for more inclusive metrics? Infection Control \& Hospital Epidemiology, 40(6), 681-685. https://doi.org/10.1017/ice.2019.43

Agency for Healthcare Research and Quality. (2015a). Plan-Do-Study-Act (PDSA) Cycle. https://innovations.ahrq.gov/qualitytools/plan-do-study-act-pdsa-cycle

Agency for Healthcare Research and Quality. (2015b). Toolkit for reducing catheter-associated urinary tract infections in hospital units: Implementing guide. https://www.ahrq.gov/sites/default/files/publications/files/implmentation-gude_0.pdf

American Nurses Association. (2017). ANA CAUTI Prevention Tool. http://nursingworld.org/ANA-CAUTI-Prevention-Tool

Andrioli, E. R., Furtado, G. H. C., \& Medeiros, E. A. (2016). Catheter-associated urinary tract infection after cardiovascular surgery: Impact of a multifaceted intervention. American Journal of Infection Control, 44(3), 289-293. https://doi.org/10.1016/j.ajic.2015.09.030

Calderon, L. E., Kavanagh, K.T., \& Rice, M. K. (2015). Questionable validity of the catheterassociated urinary tract infection metric used for value-based purchasing. American Journal of Infection Control, 43(10), 1050-1052.

https://doi.org/10.1016/j.ajic.2015.05.024

Carr, A. N., Lacambra, V. W., Naessens, J. M, Monteau, R. E., \& Park, S. H. (2017). CAUTI prevention: Streaming quality care in a progressive care unit. Journal of Medical Surgical Nursing, 26(5). http://www.medsurgnursing.net/cgi-bin/WebObjects/MSNJournal.woa

Centers for Disease Control and Prevention. (2019a). Healthcare-associated infections. Catheter-associated urinary tract infections (CAUTI). https://www.cdc.gov/hai/ca_uti/uti.html 
Centers for Disease Control and Prevention. (2017b). Urinary tract infection (catheter associated urinary tract infection [CAUTI] and non-catheter-associated urinary tract infection [UTI]) and other urinary system infection [USI]) events. https://www.cdc.gov/nhsn/pdfs/pscmanual/7psccauticurrent.pdf

Dobrzykowski, D. D., McFadden, K. L., \& Vonderembse, M. A. (2016). Examining pathways to safety and financial performance in hospitals: A study of Lean in professional service operations. Journal of Operations Management, 42, 39-51.

https://doi.org/10.1016/j.jom.2016.03.001

Doctors Hospital at Renaissance. (2019). DHR Health. https://dhrhealth.com/

Dogherty, E. J., Harrison, M. B., Graham, I. D., Vandyk, A. D., \& Burke, L. (2013). Turning knowledge into action at the point of care: The collective experience of nurses facilitating the implementation of evidence based practice. Worldviews on Evidence Based Nursing, 10(3), 129-139. https://sigmapubs.onlinelibrary.wiley.com/doi/pdf/10.1111/wvn.12009

Durant, D. J. (2017). Nurse-driven protocols and the prevention of catheter-associated urinary tract infections: A systematic review. American Journal of Infection Control, 45(12), 1331-1341. https://doi.org/10.1016j.ajic.

Dy, S., Major-Joynes, B., Peques, D., \& Bradway., C. (2016). A nurse-driven protocol for removal of indwelling urinary catheters across a multi-hospital academic healthcare system. Urologic Nursing, 36(5), 243-249. https://doi.org/10.7257/1053816X.2016.36.5.243

Fonseca, V. L., \& Veludo F. A. (2016). Prevention of catheter-associated urinary tract infection: implementation strategies of international guidelines. Revista Latino-Americana De Enfermagem (RLAE), 24, 1-9. https://doi.org doi:10.1590/1518-8345.0963.2678 
Galiczewski, J. M. \& Shurpin, K. M. (2016). An intervention to improve the catheter associated urinary tract infection rate in a medical intensive care unit: Direct observation of catheter insertion procedure. Intensive and Critical Care Nursing, 40, 26-34. https://doi.org/10.1016/j.iccn.2011.04.005

Galliano G. E. (2019). Process variation detection using missing data in a multihospital community practice anatomic pathology laboratory. Journal of Pathology Informatics, 10, 25. https://doi.org/10.4103/jpi.jpi_18_19

Gürel, E., \& Tat, M. (2017). SWOT analysis: A theoretical review. Journal of International Social Research, 10(51). https://doi.org/10.17719/jisr.2017.1832

Health Insurance Portability and Accountability Act of 1996. (1996). Public law, 104, 191. Health information privacy. https://www.hhs.gov/hipaa/for-professionals/index.htm

Hernandez, M., King, A., \& Stewart, L. (2019). Catheter-associated urinary tract infection (CAUTI) prevention and nurses' checklist documentation of their indwelling catheter management practices. Nursing Praxis in New Zealand, 35(1), 29-42. https://www.nursingpraxis.org/

Hussain, S. T., Lei, S., Akram, T., Haider, M. J., Hussain, S. H., \& Ali, M. (2018). Kurt Lewin's change model: A critical review of the role of leadership and employee involvement in organizational change. Journal of Innovation \& Knowledge, 3(3), 123-127. https://doi.org/10.1016/j.jik.2016.07.002

Institute for Healthcare Improvement. (2020.). IHI improvement capability self-assessment tool. http/app.ihi.org/facultydocument/events/event-2354/presentation-9119/document7406.L2_improvement_tool.pdf 
Johnson, S. (2018). A case study of organizational risk on hospital-acquired infections. Nursing Economics, 36(3), 128-135. http://www.nursingeconomics.net/cgibin/WebObjects/NECJournal.woa

Kogon, K., Blakemore, S., \& Wood, J. (2015). Project management for the unofficial project manager. BenBella Books, Inc.

Letica-Kriegel, A. S., Salmasian, H., Vawdrey, D.K., Youngerman, B. E., Green, R. A., Furuya, E. Y., Calfee, D. P., \& Perotte, R. (2019). Identifying the risk factors for catheterassociated urinary tract infections: A large cross-sectional study of six hospitals. $B M J$ Open, 9(2). https://doi.org/10.1136/bmjopen-2018-022137

Lewin, K. (1947). Frontiers in group dynamics: Concept, method, and reality in social science; Social equilibrium and social change. Human Relations, 1(1), 4-51. https://doi.org/10.1177/00187267470000100103

Li, C. H. (2016). Confirmatory factor analysis with ordinal data: Comparing robust maximum likelihood and diagonally weighted least squares. Behavior Research Methods, 48(3), 936-949.

Li, F., Song, M., Xu, L, Deng, B., Zhu, S., Li, X. (2018). Risk factors for catheter-associated urinary tract infection among hospitalized patients: A systematic review and metaanalysis of observational studies. Journal of Advanced Nursing, 75:57-527. https://doi.org/10.1111/jan. 13863

Makary, M., \& Daniel, M. (2016). Medical error. The third leading cause of death in the US. BMJ, 353 (i2139), 1-5. https://doi.org/10.1136/bmj.i2139

McCoy, C., Paredes, M., Allen, S., Blackey, J., Nielsen, C., Paluzzi, A., Jonas, B., \& Radovich, P. (2017). Catheter--Associated Urinary Tract Infections: Implementing a protocol to 
decrease incidence in oncology populations. Clinical Journal of Oncology

Nursing, 21(4). https://doi.org/10.1188/17.cjon.460-465

Meddings, J., Skolarus, T. A., Fowler, K. E., Bernstein, S. J., Dimick, J. B., Mann, J. D., \& Saint, S. (2019). Michigan appropriate perioperative (MAP) criteria for urinary catheter use in common general and orthopedic surgeries: Results obtained using the RAND/UCLA appropriateness method. BMJ Quality \& Safety, 28(1), 56. https://doi.org/10.1136/bmjqs2018-008025

Menegueti, M. G., Ciol, M. A., Bellissimo-Rodrigues, F., Auxiliadora-Martins, M., Gaspar, G. G., Canini, S., Basile-Filho, A., \& Laus, A. M. (2019). Long-term prevention of catheterassociated urinary tract infections among critically ill patients through the implementation of an educational program and a daily checklist for maintenance of indwelling urinary catheters: A quasi-experimental study. Medicine, 98(8), e14417. https://doi.org/10.1097/MD.0000000000014417

Mizerek, E., \& Wolf, L. (2015). To Foley or not to Foley: Emergency nurses' perceptions of clinical decision making in the use of urinary catheters in the emergency department. Journal of Emergency Nursing, 41(4), 329-334. https://doi.org/10.1016/j.jen.2014.09.009

Nelson, R., \& Staggers, N. (2018). Health informatics: An interprofessional approach (2 ${ }^{\text {nd }}$ ed.). Elsevier.

Parker, V., Giles, M., Graham, L., Suthers, B., Watts, W., O'Brien, T., \& Searles, A. (2017). Avoiding inappropriate urinary catheter use and catheter-associated urinary tract infection (CAUTI): A pre-post control intervention study. BMC Health Services Research, 17(1), 314. https://doi.org/10.1186/s12913-017-2268-2) 
Quinn, P. (2015). Chasing zero: A nurse-driven process for catheter-associated urinary tract infection reduction in a community hospital. Nursing Economics, 33(6), 302-325. www.journal-data.com/journal/nursing-economics.html

Ramazani, J., \& Jergeas, G. (2015). Project managers and the journey from good to great: The benefits of investment in project management training and education. International Journal of Project Management, 33(1), 41-52. https://doi.org/10.1016/j.ijproman.2014.03.012

Reisinger, J. D., Wojcik, A., Jenkins, I., Edson, B., Pegues, D. A., \& Greene, L. (2017). The project protects infection prevention fellowship: A model for advancing infection prevention competency, quality improvement, and patient safety. American Journal of Infection Control, 45(8), 876-882. https://doi.org/10.1016/j.ajic.2017.03.031

Scanlon, K. A., Wells, C. M., Woolforde, L., Khameraj, A., \& Baumgarten, J. (2017). Saving lives and reducing harm: A CAUTI reduction program. Nursing Economics, 35(3), 134141. https://stage.academynet.com/sites/default/files/scanlon_kerri_cauti_reduction_program_ ppt.pdf

Schaffer, M. A., Sandau, K. E., \& Diedrick, L. (2013). Evidence based practice models for organizational change: Overview and practical applications. Journal of Advanced Nursing, 69(5), 1197-1209. https://doi.org/10.1111/j.1365-2648.2012.06122.x

Schreiber, P. W., Sax, H., Wolfensberger, A., Clack, L., \& Kuster, S. P. (2018). The presentable proportion of healthcare-associated infections. Systematic review and meta-analysis. Infection Control \& Hospital Epidemiology, 39(11), 1277-1295. 
Seidle, B., Fernandez, S., \& Perry, J. L. (2016). Do leadership training and development make a difference in the public sector? A panel study. Public Administration Review, 76(4), 603613. https://doi.org/10.1111/puar.12531

Shirley, M. (2013). Lewin's theory of change as a strategic resource. The Journal of Nursing Administration, 43(2) 69-72. https://doi.org/10.1097/NNA.0b013e31827f20a9

Smith, C. (2015). On the road to zero CAUTIs: Reducing urinary catheter device days: How a culture shift, a quality-improvement project, and electronic solutions reduced one hospital's CAUTI incidence. America Nurse Today, 10(1), 46-48. https://dev01.americannursetoday.com/road-zero-cautis-reducing-urinary-catheterdevice-days/

Sylvia, M.L. \& Terhaar, M. F. (2018). Clinical analytics and data management for the DNP (2 ed.). Springer Publishing Company, LLC.

Taha, H., Raji, S. J., Khallaf, A., Abu Hija, S., Mathew, R., Rashed, H., Du Plessis, C., Allie, Z., Ellahham, S. (2017). Improving catheter associated urinary tract infection rates in the medical units. BMJ Quality Improvement Reports, 6(1). http://dx.doi.org/10.1136/bmjquality.u209593.w7966

Thomas, K. L. (2016). Reduction of catheter-associated urinary tract infections through the use of an evidence-based nursing algorithm and the implementation of shift nursing rounds: A quality improvement project. Journal of Wound Ostomy \& Continence Nursing, 43(2), 183-187. https://doi.org/10.1097/WON.0000000000000206

Watson, R. (2015). Quantitative research. Nursing Standard, 29(31). https://doi.org/10.7748/ns.29.31.44.e8681 
Wojciechowski, E., Pearsall, T., Murphy, P., \& French, E. (2016). A case review: Integrating Lewin's theory with lean's system approach for change. Online Journal of Issues in Nursing, 21(2). https://doi.org/10.3912/OJIN.Vol21No02Man04

World Health Organization. (2020). Clean care is safer care. The burden of health careassociated infection worldwide. https://www.who.int/gpsc/country_work/burden_hcai/en/

Yatim, J., Wong, K. S., Ling, M. L., Tan, S. B., Tan, K. Y., \& Hockenberry, M. (2016). A nursedriven process for timely removal of urinary catheters. International Journal of Urological Nursing, 10(3), 167-172. https://doi.org/10.7257/1053-816X.2016.36.5.243

Zurmehly, J. (2018). Implementing a nurse-driven protocol to reduce catheter-associated urinary tract infections in a long-term acute care hospital. The Journal of Continuing Education in Nursing, 49(8), 372-377. https://doi.org/10.3928/00220124-20180718-08 


\section{Table 1}

Project Budget and Revenue Description

\begin{tabular}{|c|c|c|}
\hline Anticipated Expenses & Cost & Description \\
\hline Rehabilitation Nurse & $\$ 1,320.00$ & 2 hours of training on the \\
\hline \multirow[t]{2}{*}{ Training (20) (\$33/hr.) } & & CAUTI bundle protocol to \\
\hline & & all nurse in the floor \\
\hline Educational/Training & $\$ 150.00$ & Flyers, handouts, and \\
\hline \multirow[t]{2}{*}{ Material } & & posters delineating the \\
\hline & & CAUTI bundle protocol \\
\hline Printing Supplies & $\$ 300.00$ & Ink and tonner \\
\hline Snacks and beverages & $\$ 200.00$ & Snacks to serve during the \\
\hline & & training \\
\hline Total Expenses & $\$ 1,970.00$ & \\
\hline \multicolumn{3}{|l|}{ Revenue } \\
\hline 6 CAUTIS in 2019 & $\$ 14,400.00$ & $\begin{array}{l}\text { At a cost of } \$ 2,400 \text { per } \\
\text { CAUTI case }\end{array}$ \\
\hline $\begin{array}{l}\text { From January to May } 2020 \\
\text { There } 2 \text { CAUTIs }\end{array}$ & $\$ 4,800.00$ & $\begin{array}{l}\text { At a cost of } \$ 2,400 \text { per } \\
\text { CAUTI case }\end{array}$ \\
\hline \multicolumn{3}{|l|}{$\begin{array}{l}\text { During and after } \\
\text { intervention zero CAUTIs }\end{array}$} \\
\hline Total Revenue & $\$ 9,600.00$ & \\
\hline
\end{tabular}


Table 2

Pre- and Post-Staff Education/Training

\begin{tabular}{lllllll}
\hline \multicolumn{1}{c}{ Variables } & $N$ & Mean & $S D$ & $D f$ & t-value & p-value \\
\hline Pre-Test & 24 & 37.87 & 6.29 & & & \\
Post-Test & 24 & 41.63 & 5.76 & 23 & 2.488 & 0.021 \\
\hline
\end{tabular}

Note. Significant at the $p$ value $\leq .05$ level (2-tailed) 
Table 3

Nurse Compliance to CAUTI Bundle Tool

\begin{tabular}{|c|c|c|}
\hline & Frequency & Percentage \\
\hline & $f$ & $\%$ \\
\hline Nurse Compliance to CAUTI Bundle Tool & 29 & 76 \\
\hline Nurse Non-Compliance to CAUTI Bundle Tool & 9 & 24 \\
\hline Total & 38 & 100 \\
\hline
\end{tabular}




\section{Figure 1}

\section{CAUTI Incidences}

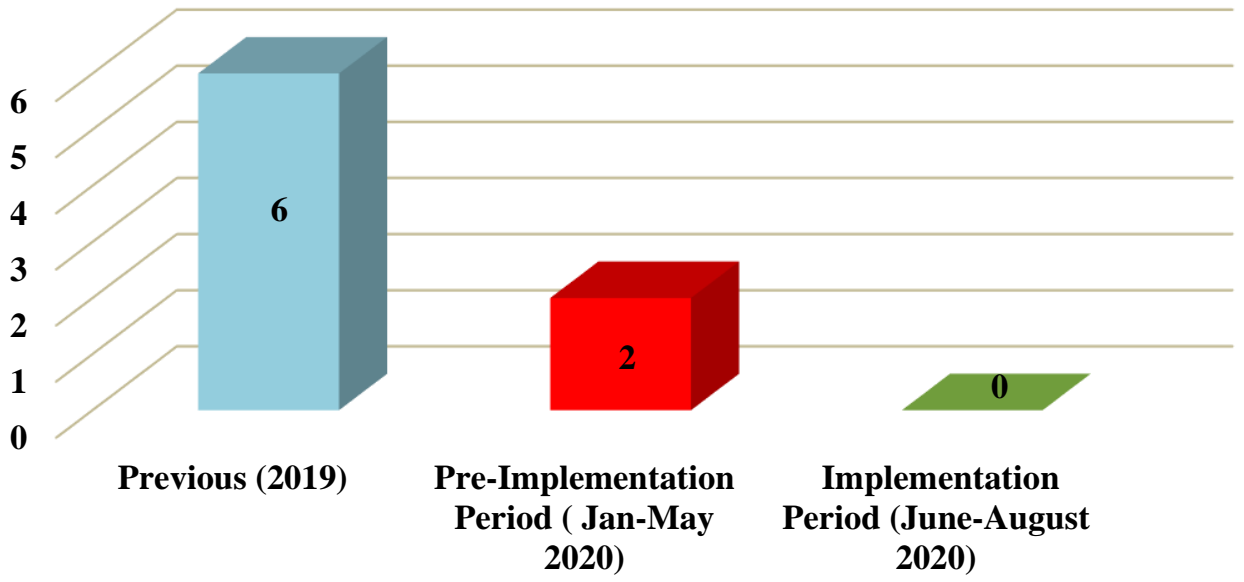




\section{Figure 2}

\section{Total Number of Re-Catheterizations}

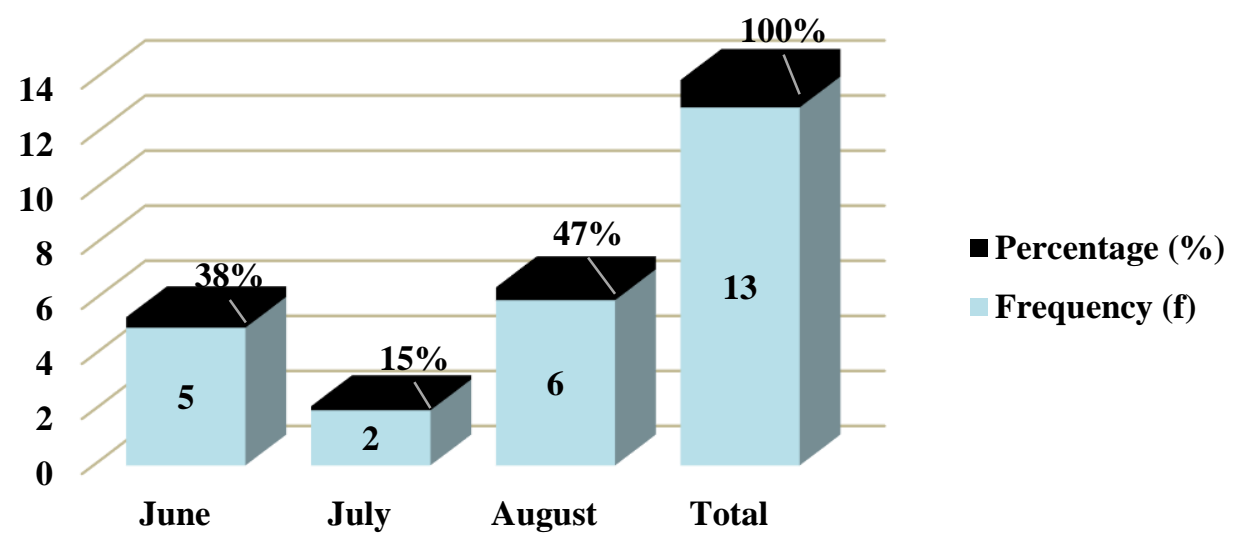




\section{Figure 3}

Total Number of Catheter Days

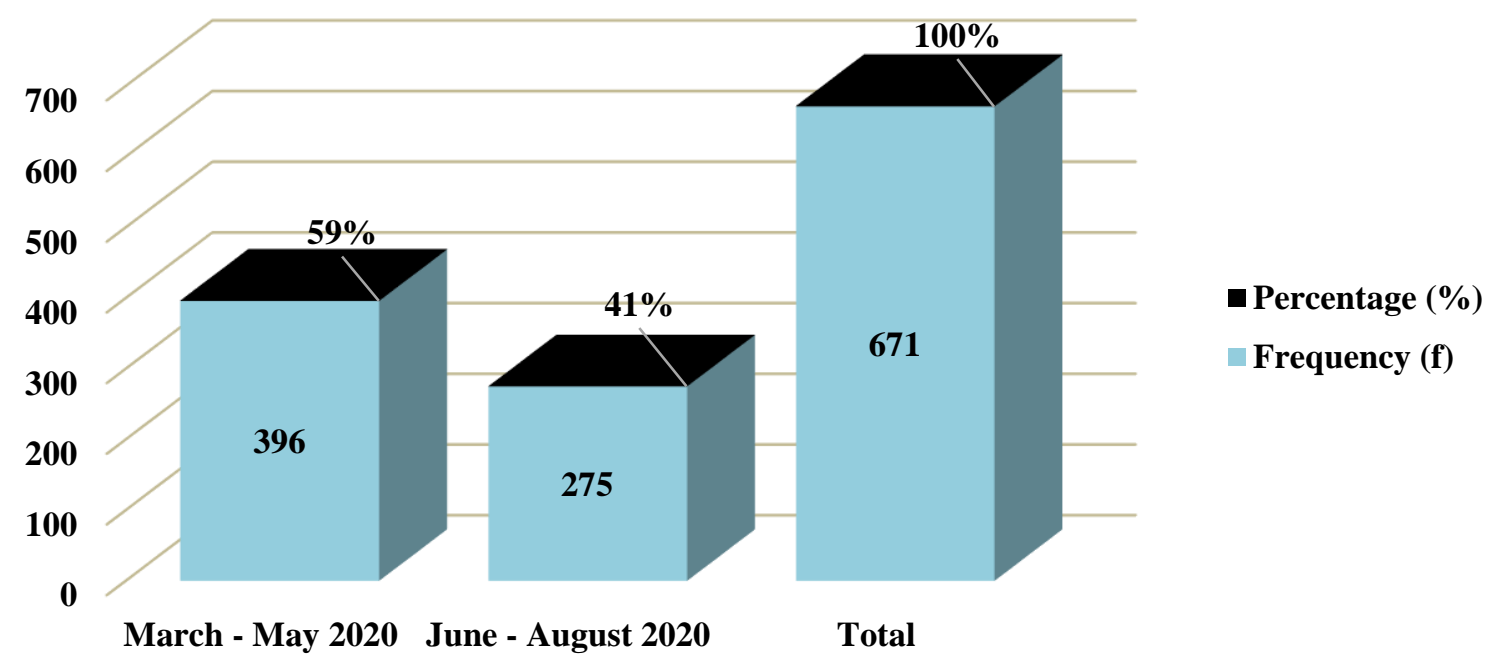




\section{Appendix A}

Summary of Primary Research Evidence

\begin{tabular}{|c|c|c|c|c|c|c|c|}
\hline Citation & Question & $\begin{array}{c}\text { Design, } \\
\text { Level } \\
\text { Quality } \\
\text { Grade }\end{array}$ & $\begin{array}{c}\text { Sample } \\
\text { Sample } \\
\text { size }\end{array}$ & $\begin{array}{c}\text { Intervention } \\
\text { Comparison } \\
\text { (Definitions } \\
\text { should } \\
\text { include any } \\
\text { specific } \\
\text { research } \\
\text { tools used } \\
\text { along with } \\
\text { reliability \& } \\
\text { validity) } \\
\end{array}$ & $\begin{array}{l}\text { Theoretic } \\
\text { al } \\
\text { Founda- } \\
\text { tion }\end{array}$ & $\begin{array}{l}\text { Outcome } \\
\text { Definition }\end{array}$ & $\begin{array}{c}\text { Usefulness } \\
\text { Results } \\
\text { Key } \\
\text { Findings }\end{array}$ \\
\hline $\begin{array}{l}\text { Andrioli, E. R., Furtado, G. H. C., \& } \\
\text { Medeiros, E. A. (2016). Catheter- } \\
\text { associated urinary tract infection after } \\
\text { cardiovascular surgery: Impact of a } \\
\text { multifaceted intervention. American } \\
\text { Journal of Infection Control, } 44(3) \text {, } \\
289-293 \text {. } \\
\text { https://doi.org/10.1016/j.ajic.2015.09. } \\
030\end{array}$ & $\begin{array}{l}\text { To find out } \\
\text { if a multi- } \\
\text { faceted } \\
\text { intervention } \\
\text { on the } \\
\text { incidence of } \\
\text { CAUTI and } \\
\text { the ratio of } \\
\text { IUCs in } \\
\text { placed, } \\
\text { evaluating } \\
\text { adherence to } \\
\text { guidelines } \\
\text { for the use } \\
\text { of IUCs }\end{array}$ & $\begin{array}{l}\text { Prospective } \\
\text {, Before- } \\
\text { and-after } \\
\text { Interventio } \\
\text { nal Study } \\
\text { Level } 1 \\
\text { Grade A }\end{array}$ & $\begin{array}{l}\text { N-216 } \\
\text { In a } \\
\text { Cardiology } \\
\text { surgical } \\
\text { unit }\end{array}$ & $\begin{array}{l}\text { Intervention } \\
\text { included } \\
\text { monitoring } \\
\text { several } \\
\text { protocols } \\
\text { implemented } \\
\text { related to } \\
\text { IUC use. To } \\
\text { evaluate } \\
\text { adherence to } \\
\text { various } \\
\text { protocols } \\
\text { during the } \\
\text { intervention } \\
\text { process, the } \\
\text { authors } \\
\text { performed } \\
\text { visits during } \\
\text { the entire }\end{array}$ & None & $\begin{array}{l}\text { The } \\
\text { intervention } \\
\text { used did not } \\
\text { minimize the } \\
\text { IUC use, the } \\
\text { incidence of } \\
\text { CAUTIs } \\
\text { slowly } \\
\text { decreased. } \\
\text { Improvement } \\
\text { s were also } \\
\text { seen in the } \\
\text { IUC insertion } \\
\text { process and } \\
\text { in IUC } \\
\text { maintenance. }\end{array}$ & $\begin{array}{l}\text { A } \\
\text { multifaceted } \\
\text { intervention } \\
\text { effectively } \\
\text { reduced } \\
\text { CAUTI } \\
\text { incidence } \\
\text { and } \\
\text { improved the } \\
\text { quality of } \\
\text { care. }\end{array}$ \\
\hline
\end{tabular}




\begin{tabular}{|c|c|c|c|c|c|c|c|}
\hline & & & & $\begin{array}{l}\text { period on } \\
\text { different day } \\
\text { and at } \\
\text { different } \\
\text { times. The } \\
\text { pre-and-post } \\
\text { intervention } \\
\text { demonstrated } \\
\text { no statistical } \\
\text { significance } \\
\text { but a } \\
\text { reduction in } \\
\text { the CAUTI } \\
\text { was evident. }\end{array}$ & & & \\
\hline $\begin{array}{l}\text { Carr, A. N., Lacambra, V. W., } \\
\text { Naessens, J. M, Monteau, R. E., \& } \\
\text { Park, S. H. (2017). CAUTI } \\
\text { prevention: Streaming quality care in } \\
\text { a progressive care unit. Journal of } \\
\text { Medical Surgical Nursing, 26(5). } \\
\text { http://www.medsurgnursing.net/cgi- } \\
\text { bin/WebObjects/MSNJournal.woa }\end{array}$ & $\begin{array}{l}\text { To eliminate } \\
\text { CAUTIs on } \\
\text { a 27-bed } \\
\text { progressive } \\
\text { care unit } \\
\text { (PCU) using } \\
\text { the } \\
\text { following } \\
\text { sustainable } \\
\text { interventions } \\
\text { : (1) Audit } \\
\text { the staff } \\
\text { adherence to } \\
\text { use CAUTI } \\
\text { prevention } \\
\text { form, (2) } \\
\text { Audit staff } \\
\text { electronic } \\
\text { documentati } \\
\text { on of } \\
\text { catheter care } \\
\text { using the }\end{array}$ & $\begin{array}{l}\text { Continuous } \\
\text { EBP } \\
\text { project } \\
\text { Level 1 } \\
\text { Grade A }\end{array}$ & $\begin{array}{l}\text { 27-bed } \\
\text { Progressiv } \\
\text { e Care Unit } \\
\text { were adults } \\
\text { with acute } \\
\text { and } \\
\text { chronic } \\
\text { diseases. } \\
\text { N-35 } \\
\text { registered } \\
\text { nurses and } \\
\text { N-35 } \\
\text { patient } \\
\text { care } \\
\text { technicians }\end{array}$ & $\begin{array}{l}\text { (1) Audit the } \\
\text { staff } \\
\text { adherence to } \\
\text { use CAUTI } \\
\text { prevention } \\
\text { form, (2) } \\
\text { Audit staff } \\
\text { electronic } \\
\text { documentati } \\
\text { on of } \\
\text { catheter care } \\
\text { using the } \\
\text { CAUTI } \\
\text { bundle audit } \\
\text { tool, and (3) } \\
\text { National } \\
\text { Database of } \\
\text { Nursing } \\
\text { Quality } \\
\text { Indicators } \\
\text { CAUTI rates } \\
\text { data. A pre- }\end{array}$ & $\begin{array}{l}\text { Six Sigma } \\
\text { DMAIC } \\
\text { (define, } \\
\text { measure, } \\
\text { analyze, } \\
\text { improve, } \\
\text { control) }\end{array}$ & $\begin{array}{l}\text { After } \\
\text { implementati } \\
\text { on of project, } \\
\text { the unit } \\
\text { achieved and } \\
\text { maintained a } \\
\text { CAUTI rate } \\
\text { of } 0 \text { for } 22 \\
\text { months with } \\
\text { a reduction } \\
\text { of } 38 \% \text { of } \\
\text { catheter } \\
\text { days. }\end{array}$ & $\begin{array}{l}\text { The CAUTI } \\
\text { bundle } \\
\text { effectively } \\
\text { eliminated } \\
\text { CAUTI form } \\
\text { the unit. } \\
\text { Consistent } \\
\text { staff training } \\
\text { during team } \\
\text { huddles and } \\
\text { weekly } \\
\text { audits also } \\
\text { helped to } \\
\text { sustain the } \\
\text { success of } \\
\text { the project. } \\
\text { CAUTI } \\
\text { prevention } \\
\text { interventions } \\
\text { have become } \\
\text { a continuous } \\
\text { change in the }\end{array}$ \\
\hline
\end{tabular}




\begin{tabular}{|c|c|c|c|c|c|c|c|}
\hline & $\begin{array}{l}\text { CAUTI } \\
\text { bundle audit } \\
\text { tool, and (3) } \\
\text { National } \\
\text { Database of } \\
\text { Nursing } \\
\text { Quality } \\
\text { Indicators } \\
\text { CAUTI rates } \\
\text { data }\end{array}$ & & & $\begin{array}{l}\text { and-post-test } \\
\text { was } \\
\text { completed to } \\
\text { measure } \\
\text { results. The } \\
\text { medical } \\
\text { record was } \\
\text { used to } \\
\text { collect date } \\
\text { and conduct } \\
\text { audits } \\
\text { protocol was } \\
\text { being carried } \\
\text { out as } \\
\text { planned. }\end{array}$ & & & $\begin{array}{l}\text { practice of } \\
\text { nursing staff. }\end{array}$ \\
\hline $\begin{array}{l}\text { Galiczewski, J. M. \& Shurpin, K. M. } \\
\text { (2016). An intervention to improve } \\
\text { the catheter associated urinary tract } \\
\text { infection rate in a medical intensive } \\
\text { care unit: Direct observation of } \\
\text { catheter insertion procedure. } \\
\text { Intensive and Critical Care Nursing, } \\
40,26-34 \text {. } \\
\text { https://doi.org/10.1016/j.iccn.2011.04 } \\
.005\end{array}$ & $\begin{array}{l}\text { To } \\
\text { determine if } \\
\text { current } \\
\text { procedure } \\
\text { compared to } \\
\text { the direct } \\
\text { observation } \\
\text { of the } \\
\text { urinary } \\
\text { catheter } \\
\text { insertion } \\
\text { procedure } \\
\text { reduces the } \\
\text { use of } \\
\text { catheters and } \\
\text { the rate of } \\
\text { urinary tract } \\
\text { infection. }\end{array}$ & $\begin{array}{l}\text { Quasi- } \\
\text { experiment } \\
\text { al case } \\
\text { control } \\
\text { study } \\
\text { Level } 2 \\
\text { Grade B }\end{array}$ & $\begin{array}{l}\text { N-74 } \\
\text { During } \\
\text { Phase I: } \\
\text { Retrospecti } \\
\text { ve data } \\
\text { reviewed } \\
\text { on the use } \\
\text { of urinary } \\
\text { catheter } \\
\text { infection } \\
\text { rates when } \\
\text { practitioner } \\
\text { s followed } \\
\text { the } \\
\text { standard } \\
\text { insertion } \\
\text { algorithm } \\
\text { used by the } \\
\text { institution. } \\
\text { N-66 } \\
\text { during }\end{array}$ & $\begin{array}{l}\text { The } \\
\text { intervention } \\
\text { is to directly } \\
\text { observe the } \\
\text { insertion of } \\
\text { the urinary } \\
\text { catheter. } \\
\text { The } \\
\text { intervention } \\
\text { was } \\
\text { compared to } \\
\text { the standard } \\
\text { insertion } \\
\text { protocol. } \\
\text { A 13-item } \\
\text { critical } \\
\text { element } \\
\text { checklist was } \\
\text { developed } \\
\text { based on the } \\
\text { institution's } \\
\end{array}$ & $\begin{array}{l}\text { The chain } \\
\text { of } \\
\text { infection } \\
\text { theory. }\end{array}$ & $\begin{array}{l}\text { Before } \\
\text { implementati } \\
\text { on of } \\
\text { intervention, } \\
\text { the rate of } \\
\text { CAUTI } \\
\text { ranged from } \\
0 \text { to } 3.26 \text { per } \\
1000 \text { catheter } \\
\text { days with a } \\
\text { mean of } 2.24 \\
\text { during phase } \\
\text { I. The overall } \\
\text { mean } \\
\text { monthly rate } \\
\text { of CAUTI in } \\
\text { MICU } \\
\text { declined } \\
\text { from } 2.24 \text { to } \\
0 \text { per } 1000 \\
\text { catheter days }\end{array}$ & $\begin{array}{l}\text { In Phase II, } \\
\text { data from } \\
\text { this EBP } \\
\text { study } \\
\text { supports the } \\
\text { direct } \\
\text { observation } \\
\text { of } \\
\text { intervention } \\
\text { to be applied } \\
\text { to the } \\
\text { catheter } \\
\text { placement } \\
\text { algorithm to } \\
\text { ensure } \\
\text { adherence to } \\
\text { guidelines. } \\
\text { The } \\
\text { opportunity } \\
\text { to provide } \\
\text { immediate }\end{array}$ \\
\hline
\end{tabular}




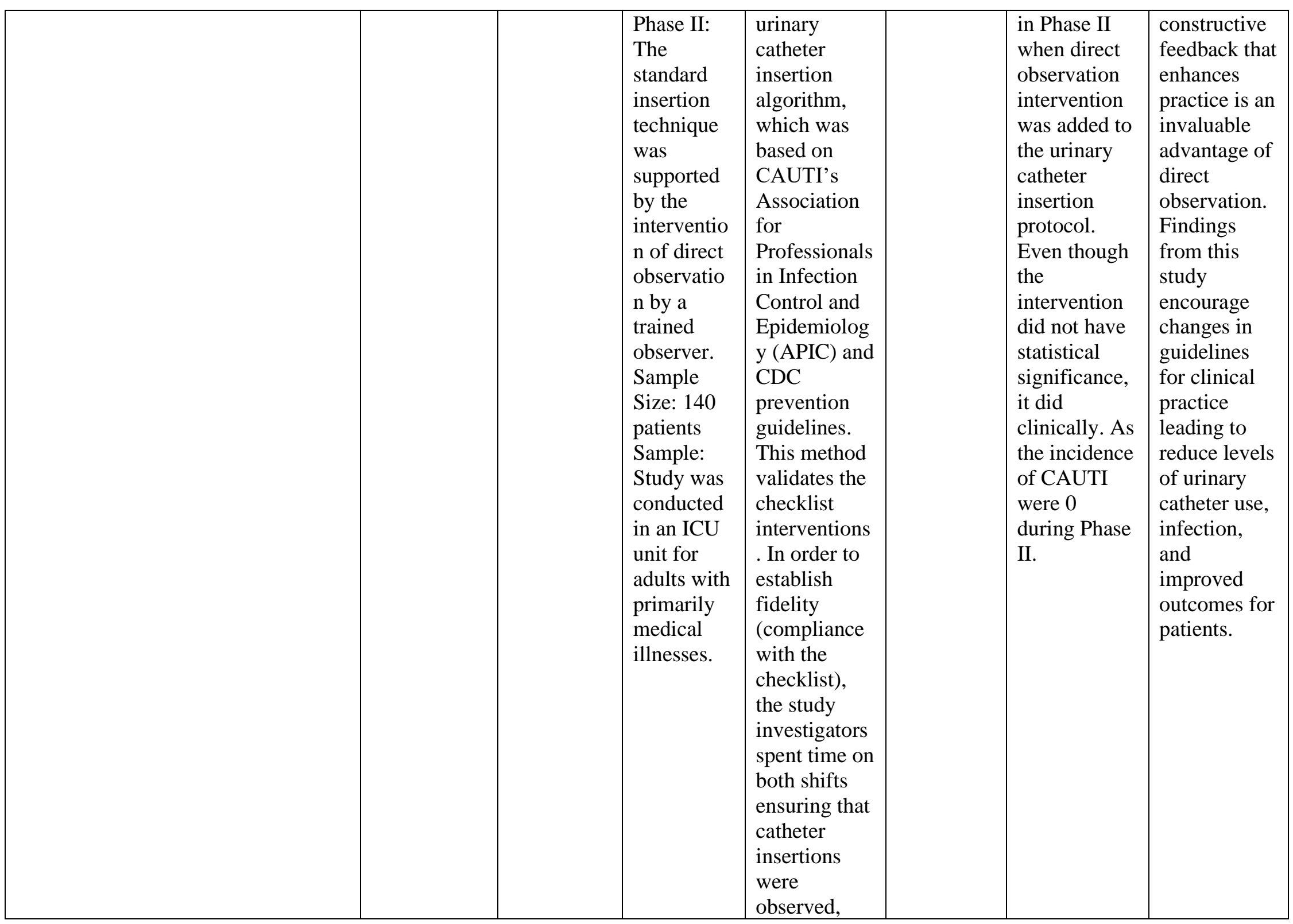




\begin{tabular}{|c|c|c|c|c|c|c|c|}
\hline & & & & $\begin{array}{l}\text { and the } \\
\text { checklist was } \\
\text { used } \\
\text { correctly. }\end{array}$ & & & \\
\hline $\begin{array}{l}\text { Giles, M., Watts, W., O’Brien, S., } \\
\text { Paul, M., Bantawa, K. (2015). Does } \\
\text { our bundle stack up: Innovative } \\
\text { nurse-led changes for preventing } \\
\text { catheter-associated urinary tract } \\
\text { infection (CAUTI)? Healthcare } \\
\text { Infection, 20, 62-71. } \\
\text { https://doi.org/10.1071/HI14035 }\end{array}$ & $\begin{array}{l}\text { To learn if } \\
\text { implementin } \\
\text { g an } \\
\text { innovative } \\
\text { nurse-led } \\
\text { model of } \\
\text { urinary } \\
\text { catheter use } \\
\text { and } \\
\text { management } \\
\text { using } \\
\text { evidence- } \\
\text { based ' } \\
\text { bundle } \\
\text { interventions } \\
\text { ' to decrease } \\
\text { or eliminate } \\
\text { the } \\
\text { incidence of } \\
\text { catheter- } \\
\text { associated } \\
\text { urinary tract } \\
\text { (CAUTI) } \\
\text { infections. }\end{array}$ & $\begin{array}{l}\text { A pre- and } \\
\text { post-Study } \\
\text { Design } \\
\text { Level } 1 \\
\text { Grade A }\end{array}$ & $\begin{array}{l}\text { Two acute } \\
\text { care } \\
\text { inpatient } \\
\text { wards } \\
\text { N-105 }\end{array}$ & $\begin{array}{l}\text { Phase one } \\
\text { involved a } \\
\text { clinical data } \\
\text { collection } \\
\text { pre } \\
\text { intervention } \\
\text { on all } \\
\text { inpatients } \\
\text { receiving an } \\
\text { IUC over a } \\
\text { 3-month } \\
\text { period from } \\
\text { February to } \\
\text { April 2013. } \\
\text { A staff } \\
\text { survey } \\
\text { assessed } \\
\text { knowledge } \\
\text { and skills } \\
\text { and an } \\
\text { evidence- } \\
\text { based care } \\
\text { bundle, } \\
\text { nurse-led } \\
\text { protocols, } \\
\text { and } \\
\text { education } \\
\text { resources } \\
\text { were } \\
\text { developed } \\
\text { through } \\
\text { collaboration }\end{array}$ & None & $\begin{array}{l}\text { Pre-assessed } \\
\text { data showed } \\
\text { a high IUC } \\
\text { usage rate: } \\
31 \% \text { of all } \\
\text { orthopedic } \\
\text { ward } \\
\text { patients, and } \\
25 \% \text { of } \\
\text { urology ward } \\
\text { patients. } \\
\text { Compliance } \\
\text { with existing } \\
\text { standards } \\
\text { was } \\
\text { inconsistent } \\
\text { and there was } \\
\text { insufficient } \\
\text { documentatio } \\
\text { n on IUCs. } \\
\text { The total } \\
\text { CAUTI rate } \\
2.2 \% \text { of a } \\
\text { IUC patients } \\
\text { was relatively low }\end{array}$ & $\begin{array}{l}\text { The } \\
\text { development } \\
\text { of a } \\
\text { systematic } \\
\text { and } \\
\text { standardized } \\
\text { approach to } \\
\text { IUC care for } \\
\text { inpatients } \\
\text { using } \\
\text { bundle care } \\
\text { interventions } \\
\text { potentially } \\
\text { reduce IUC } \\
\text { use, provide } \\
\text { a clear } \\
\text { pathway for } \\
\text { nurse } \\
\text { initiated IUC } \\
\text { removal } \\
\text { and reduce } \\
\text { the incidence } \\
\text { of catheter- } \\
\text { associated } \\
\text { urinary tract } \\
\text { infections } \\
\text { (CAUTI). }\end{array}$ \\
\hline
\end{tabular}




\begin{tabular}{|c|c|c|c|c|c|c|c|}
\hline & & & & $\begin{array}{l}\text { with } \\
\text { clinicians. } \\
\text { Phase two } \\
\text { involved } \\
\text { implementati } \\
\text { on and Phase } \\
\text { three was an } \\
\text { evaluation } \\
\text { with the } \\
\text { primary } \\
\text { outcome } \\
\text { targets being } \\
\text { reduced IUC } \\
\text { usage, days } \\
\text { IUC in situ } \\
\text { and } \\
\text { incidence } \\
\text { of CAUTI. }\end{array}$ & & & \\
\hline $\begin{array}{l}\text { Hernandez, M., King, A., \& Stewart, } \\
\text { L. (2019). Catheter-associated } \\
\text { urinary tract infection (CAUTI) } \\
\text { prevention and nurses' checklist } \\
\text { documentation of their indwelling } \\
\text { catheter management practices. } \\
\text { Nursing Praxis in New Zealand, } \\
35(1), 29-42 . \\
\text { https://www.nursingpraxis.org/ }\end{array}$ & $\begin{array}{l}\text { To } \\
\text { investigate } \\
\text { the impact of } \\
\text { CAUTI, } \\
\text { education } \\
\text { package on } \\
\text { nurses' } \\
\text { knowledge } \\
\text { and IUC } \\
\text { management } \\
\text { on the newly } \\
\text { implemented } \\
\text { CAUTI } \\
\text { prevention } \\
\text { bundle. }\end{array}$ & $\begin{array}{l}\text { A pre- and } \\
\text { post- } \\
\text { quantitativ } \\
\text { e- EBP } \\
\text { Initiative } \\
\text { Level } 1 \\
\text { Grade A. }\end{array}$ & $\begin{array}{l}\text { N-50 } \\
\text { nurses } \\
\text { working at } \\
\text { two } \\
\text { surgical } \\
\text { units. }\end{array}$ & $\begin{array}{l}\text { The } \\
\text { intervention } \\
\text { was the } \\
\text { CAUTI } \\
\text { prevention } \\
\text { bundle. The } \\
\text { bundle has } \\
\text { five } \\
\text { components: } \\
\text { appropriate } \\
\text { catheter } \\
\text { indications, } \\
\text { hand } \\
\text { hygiene, } \\
\text { insertion } \\
\text { technique, } \\
\text { catheter } \\
\text { maintenance, }\end{array}$ & None & $\begin{array}{l}\text { Findings } \\
\text { indicated that } \\
\text { the CAUTI } \\
\text { education } \\
\text { package had } \\
\text { a significant } \\
\text { impact } \\
\text { ( }<0.0001 \text { ) } \\
\text { on the } \\
\text { overall } \\
\text { knowledge of } \\
\text { CAUTI } \\
\text { prevention } \\
\text { among } \\
\text { nurses and } \\
\text { on each of } \\
\text { the five } \\
\text { components }\end{array}$ & $\begin{array}{l}\text { The authors } \\
\text { recommend } \\
\text { a } \\
\text { continuous- } \\
\text { in-service } \\
\text { nursing } \\
\text { education on } \\
\text { the EBP } \\
\text { CAUTI } \\
\text { prevention } \\
\text { bundle to } \\
\text { comply with } \\
\text { the new } \\
\text { guidelines } \\
\text { that have } \\
\text { demonstrated } \\
\text { to decrease }\end{array}$ \\
\hline
\end{tabular}




\begin{tabular}{|c|c|c|c|c|c|c|c|}
\hline & & & & $\begin{array}{l}\text { and catheter } \\
\text { removal. A } \\
\text { pre-and post- } \\
\text { test was } \\
\text { completed by } \\
\text { the nurses } \\
\text { after } \\
\text { implementati } \\
\text { on of the } \\
\text { CAUTI } \\
\text { prevention } \\
\text { bundle. The } \\
\text { results } \\
\text { demonstrated } \\
\text { that there is a } \\
\text { need for on- } \\
\text { going } \\
\text { education for } \\
\text { the nurses to } \\
\text { effectively } \\
\text { comply with } \\
\text { the new } \\
\text { standardized } \\
\text { protocol. }\end{array}$ & & $\begin{array}{l}\text { of catheter } \\
\text { use }(p<0.05)\end{array}$ & $\begin{array}{l}\text { or eliminate } \\
\text { CAUTIs. }\end{array}$ \\
\hline $\begin{array}{l}\text { Letica-Kriegel, A. S., Salmasian, H., } \\
\text { Vawdrey, D.K., Youngerman, B. E., } \\
\text { Green, R. A., Furuya, E. Y., Calfee, } \\
\text { D. P., \& Perotte, R. (2019). } \\
\text { Identifying the risk factors for } \\
\text { catheter-associated urinary tract } \\
\text { infections: A large cross-sectional } \\
\text { study of six hospitals. BMJ Open, } \\
\text { 9(2). } \\
\text { https://doi.org/10.1136/bmjopen- } \\
\text { 2018-022137 }\end{array}$ & $\begin{array}{l}\text { To examine } \\
\text { how the risk } \\
\text { for CAUTI } \\
\text { changes } \\
\text { over time. } \\
\text { Additionally } \\
\text {, to assess } \\
\text { whether time } \\
\text { from } \\
\text { catheter } \\
\text { insertion to }\end{array}$ & $\begin{array}{l}\text { Retrospecti } \\
\text { ve cohort } \\
\text { study } \\
\text { Level } 2 \\
\text { Grade C }\end{array}$ & $\begin{array}{l}\text { N-2500 } \\
\text { Two } \\
\text { community } \\
\text { hospitals }\end{array}$ & $\begin{array}{l}\text { The } \\
\text { adult } \\
\text { population } \\
\text { (18+ years of } \\
\text { age) had a } \\
\text { total of } 517 \\
335 \\
\text { catheter days } \\
\text { and a CAUTI } \\
\text { rate of } 1.61 \\
\text { (95\% CI: } 1.51 \\
\text { to }\end{array}$ & None & $\begin{array}{l}\text { The study } \\
\text { population } \\
\text { was } 47926 \\
\text { patients } \\
\text { who had } 61 \\
047 \\
\text { catheterizatio } \\
\text { ns, of which } \\
861(1.41 \%) \\
\text { resulted in a } \\
\text { CAUTI. }\end{array}$ & $\begin{array}{l}\text { Using a very } \\
\text { large data } \\
\text { set, we } \\
\text { demonstrated } \\
\text { the } \\
\text { incremental } \\
\text { risk of } \\
\text { CAUTI } \\
\text { associated } \\
\text { with each } \\
\text { additional }\end{array}$ \\
\hline
\end{tabular}




\begin{tabular}{|c|c|c|c|c|c|c|c|}
\hline & $\begin{array}{l}\text { CAUTI } \\
\text { event varied } \\
\text { according to } \\
\text { risk } \\
\text { factors such } \\
\text { as age, sex, } \\
\text { patient type }\end{array}$ & & & $\begin{array}{l}1.73) \text { per } \\
1000 \text { catheter } \\
\text { days, } \\
\text { representing } \\
\text { a non- } \\
\text { statistically } \\
\text { significant } \\
\text { difference }\end{array}$ & & $\begin{array}{l}\text { CAUTI rates } \\
\text { were found } \\
\text { to increase } \\
\text { non-linearly } \\
\text { for each } \\
\text { additional } \\
\text { day of } \\
\text { catheterizatio } \\
\text { n; } \\
\text { CAUTI-free } \\
\text { survival was } \\
97.3 \% \text { (CI: } \\
97.1 \text { to } 97.6) \\
\text { at } 10 \\
\text { days, } 88.2 \% \\
\text { (CI: } 86.9 \text { to } \\
89.5) \text { at } 30 \\
\text { days and } \\
71.8 \% \\
\text { (CI: } 66.3 \text { to } \\
77.8 \text { ) at } 60 \\
\text { days. This } \\
\text { translated to } \\
\text { an } \\
\text { instantaneous } \\
\text { HR of. } 49 \%- \\
1.65 \% \text { in the } \\
10-60 \\
\text { daytime } \\
\text { range. }\end{array}$ & $\begin{array}{l}\text { day of } \\
\text { catheterizatio } \\
\text { n, as well as } \\
\text { the } \\
\text { risk factors } \\
\text { that increase } \\
\text { the hazard } \\
\text { for CAUTI. } \\
\text { Special } \\
\text { attention } \\
\text { should be } \\
\text { given to } \\
\text { patients } \\
\text { carrying } \\
\text { these risk } \\
\text { factors, for } \\
\text { example, } \\
\text { females or } \\
\text { those with } \\
\text { mobility } \\
\text { issues. }\end{array}$ \\
\hline $\begin{array}{l}\text { McCoy, C., Paredes, M., Allen, S., } \\
\text { Blackey, J., Nielsen, C., Paluzzi, A., } \\
\text { Jonas, B., \& Radovich, P. (2017). } \\
\text { Catheter--Associated Urinary Tract } \\
\text { Infections: Implementing a protocol } \\
\text { to decrease incidence in oncology }\end{array}$ & $\begin{array}{l}\text { Preventing } \\
\text { CAUTIs in } \\
\text { the inpatient } \\
\text { oncology } \\
\text { population } \\
\text { by }\end{array}$ & $\begin{array}{l}\text { EBP } \\
\text { project } \\
\text { Level } 1 \\
\text { Grade A }\end{array}$ & $\begin{array}{l}\text { Oncology } \\
\text { population } \\
\mathrm{N}-442\end{array}$ & $\begin{array}{l}\text { To } \\
\text { implement } \\
\text { an evidence- } \\
\text { based nurse- } \\
\text { driven } \\
\text { protocol for }\end{array}$ & $\begin{array}{l}\text { Model of } \\
\text { Improvem } \\
\text { ent } \\
\text { Framewor } \\
\text { k }\end{array}$ & $\begin{array}{l}\text { Outcome } \\
\text { Definition: } \\
\text { CAUTI rates } \\
\text { remained } \\
\text { unchanged, } \\
\text { but infections }\end{array}$ & $\begin{array}{l}\text { Findings of } \\
\text { this study } \\
\text { state the } \\
\text { importance } \\
\text { of RNs to } \\
\text { protect }\end{array}$ \\
\hline
\end{tabular}




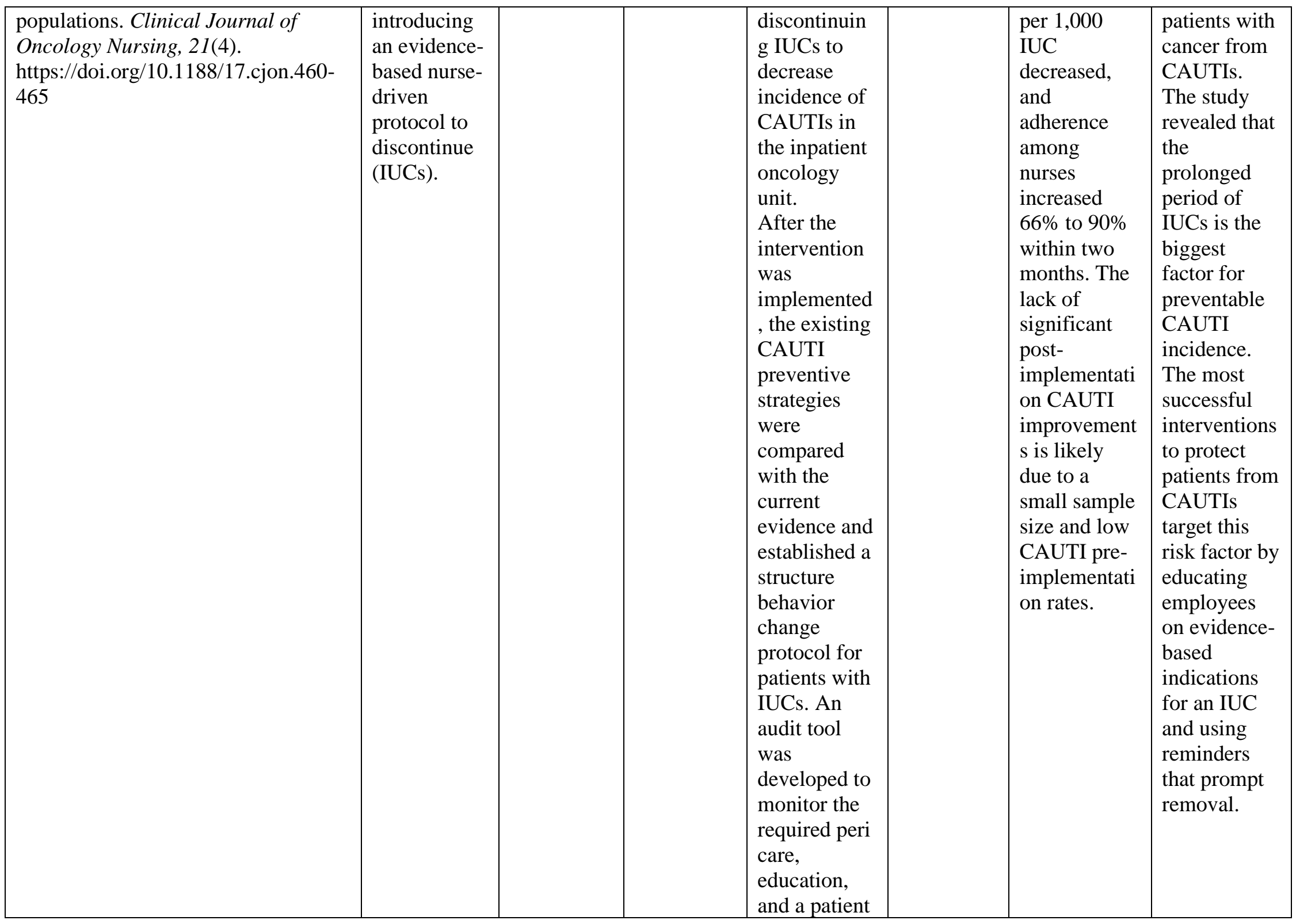




\begin{tabular}{|c|c|c|c|c|c|c|c|}
\hline & & & & $\begin{array}{l}\text { care plan to } \\
\text { assess } \\
\text { nurse's } \\
\text { compliance } \\
\text { with the } \\
\text { newly } \\
\text { implemented } \\
\text { protocol. }\end{array}$ & & & \\
\hline $\begin{array}{l}\text { Parker, V., Giles, M., Graham, L., } \\
\text { Suthers, B., Watts, W., O'Brien, T., \& } \\
\text { Searles, A. (2017). } \\
\text { Avoiding inappropriate urinary } \\
\text { catheter use and catheter-associated } \\
\text { urinary tract } \\
\text { infection (CAUTI): A pre-post } \\
\text { control intervention study. BMC } \\
\text { Health Services } \\
\text { Research, 17(1), 314. } \\
\text { https://doi.org/10.1186/s12913-017- } \\
\text { 2268-2) }\end{array}$ & $\begin{array}{l}\text { To reduce } \\
\text { indwelling } \\
\text { urinary } \\
\text { catheter } \\
\text { (IDC) usage } \\
\text { rates by } \\
\text { reducing } \\
\text { inadequate } \\
\text { urinary } \\
\text { catherization } \\
\text { and duration } \\
\text { of catheter. }\end{array}$ & $\begin{array}{l}\text { A Mixed } \\
\text { Method } \\
\text { Approach } \\
\text { Level } 3 \\
\text { Grade B }\end{array}$ & $\begin{array}{l}\text { Adult } \\
\text { patients in } \\
\text { two } \\
\text { different } \\
\text { acute } \\
\text { healthcare } \\
\text { districts. } \\
\text { Sample } \\
\text { size: } \mathrm{N}- \\
500\end{array}$ & $\begin{array}{l}\text { The No } \\
\text { CAUTI } \\
\text { Bundle } \\
\text { intervention } \\
\text { was } \\
\text { measured } \\
\text { with a pre- } \\
\text { and post-test. } \\
\text { The } \\
\text { electronic } \\
\text { medical } \\
\text { record } \\
\text { assisted in } \\
\text { the collection } \\
\text { of data to } \\
\text { compare the } \\
\text { pre and post } \\
\text { results of } \\
\text { intervention. }\end{array}$ & $\begin{array}{l}\text { The } \\
\text { Template } \\
\text { for } \\
\text { Interventio } \\
\mathrm{n} \\
\text { Descriptio } \\
\mathrm{n} \text { and } \\
\text { Replicatio } \\
\mathrm{n} \\
\text { (TIDieR). } \\
\text { The } \\
\text { "bundle } \\
\text { interventio } \\
\text { n" }\end{array}$ & $\begin{array}{l}\text { Implementati } \\
\text { on of EBP } \\
\text { strategies } \\
\text { were } \\
\text { specifically } \\
\text { outlined } \\
\text { using the } \\
\text { TIDieR } \\
\text { method, } \\
\text { allowing for } \\
\text { better } \\
\text { replication of } \\
\text { intervention } \\
\text { approaches } \\
\text { and } \\
\text { implementati } \\
\text { on } \\
\text { techniques. } \\
\text { The outcome } \\
\text { results were } \\
\text { that it } \\
\text { enhanced } \\
\text { patient safety } \\
\text { through } \\
\text { comprehensi } \\
\text { ve clinical } \\
\text { protocol }\end{array}$ & $\begin{array}{l}\text { The } \\
\text { implementati } \\
\text { on of the No } \\
\text { CAUTI } \\
\text { Bundle } \\
\text { demonstrated } \\
\text { to reduce } \\
\text { CAUTIs in } \\
\text { acute } \\
\text { healthcare } \\
\text { districts. The } \\
\text { author } \\
\text { suggested } \\
\text { that the } \\
\text { intervention } \\
\text { lead to a } \\
\text { significant } \\
\text { improvement } \\
\text { of patient } \\
\text { satisfaction } \\
\text { and } \\
\text { outcomes of } \\
\text { healthcare. }\end{array}$ \\
\hline
\end{tabular}




\begin{tabular}{|c|c|c|c|c|c|c|c|}
\hline & & & & & & $\begin{array}{l}\text { management } \\
\text { evaluation, } \\
\text { and } \\
\text { implementati } \\
\text { on. }\end{array}$ & \\
\hline $\begin{array}{l}\text { Quinn, P. (2015), Chasing zero: A } \\
\text { nurse-driven process for catheter- } \\
\text { associated urinary tract infection } \\
\text { reduction in a community hospital. } \\
\text { Nursing Economics, 33(6), 302-325. } \\
\text { www.journal- } \\
\text { data.com/journal/nursing- } \\
\text { economics.html }\end{array}$ & $\begin{array}{l}\text { To learn if a } \\
\text { nurse-driven } \\
\text { protocol } \\
\text { decreases } \\
\text { CAUTIs }\end{array}$ & $\begin{array}{l}\text { EBP } \\
\text { project } \\
\text { Level } 1 \\
\text { Grade A }\end{array}$ & $\begin{array}{l}\text { N-301 } \\
\text { Communit } \\
\text { y hospital }\end{array}$ & $\begin{array}{l}\text { A } \\
\text { nurse-driven } \\
\text { process for } \\
\text { CAUTI } \\
\text { prevention } \\
\text { was } \\
\text { implemented } \\
\text { with an 8- } \\
\text { point } \\
\text { protocol } \\
\text { for } \\
\text { indication, } \\
\text { physician } \\
\text { collaboration } \\
\text {, education, } \\
\text { and } \\
\text { monitoring. } \\
\text { The facility } \\
\text { saw a decline } \\
\text { in CAUTIs } \\
\text { to 0.2/1000 } \\
\text { in } \\
\text { 2013.These } \\
\text { results } \\
\text { indicated a } \\
\text { direct } \\
\text { relationship } \\
\text { between the } \\
\text { utilization of } \\
\text { a nurse- } \\
\text { driven }\end{array}$ & None & $\begin{array}{l}\text { This } \\
\text { intervention } \\
\text { did } \\
\text { not allow for } \\
\text { nurses to } \\
\text { independentl } \\
\text { y discontinue } \\
\text { utilization of } \\
\text { the urinary } \\
\text { catheters. } \\
\text { nevertheless, } \\
\text { the } \\
\text { intervention } \\
\text { provided an } \\
\text { algorithm to } \\
\text { guide nurses } \\
\text { on whether } \\
\text { to seek } \\
\text { physicians' } \\
\text { orders to } \\
\text { continue or } \\
\text { discontinue } \\
\text { the catheter } \\
\text { daily }\end{array}$ & $\begin{array}{l}\text { Study } \\
\text { demonstrated } \\
\text { a UTI rates } \\
\text { decreased } \\
\text { from } \\
4.9 / 1000 \\
\text { catheter days } \\
\text { in } 2008 \text { to } \\
3.9 / 1000 \\
\text { catheter days } \\
\text { in } 2009 \text {. } \\
\text { Catheter } \\
\text { days } \\
\text { declined } \\
\text { from } 22,212 \\
\text { in } 2008 \text { to } \\
13,249 \text { in } \\
2012 \text {. }\end{array}$ \\
\hline
\end{tabular}




\begin{tabular}{|c|c|c|c|c|c|c|c|}
\hline & & & & $\begin{array}{l}\text { protocol, and } \\
\text { catheter } \\
\text { utilization, } \\
\text { dwell time, } \\
\text { and CAUTI } \\
\text { rates }\end{array}$ & & & \\
\hline $\begin{array}{l}\text { Smith, C. (2015). On the road to zero } \\
\text { CAUTIs: Reducing urinary catheter } \\
\text { device days: How a culture shift, a } \\
\text { quality-improvement project, and } \\
\text { electronic solutions reduced one } \\
\text { hospital's CAUTI incidence. America } \\
\text { Nurse Today, 10(1), 46-48. } \\
\text { https://dev01.americannursetoday.co } \\
\text { m/road-zero-cautis-reducing-urinary- } \\
\text { catheter- }\end{array}$ & $\begin{array}{l}\text { To find out } \\
\text { if } \\
\text { implementin } \\
g \text { a CAUTI } \\
\text { bundle } \\
\text { decreases } \\
\text { the number } \\
\text { of IUC } \\
\text { inserted and } \\
\text { reduce the } \\
\text { amount of } \\
\text { time they } \\
\text { remain in } \\
\text { place. }\end{array}$ & $\begin{array}{l}\text { Quality- } \\
\text { Improveme } \\
\text { nt Initiative } \\
\text { Level } 2 \\
\text { Grade B }\end{array}$ & $\begin{array}{l}\text { N-140 } \\
\text { Communit } \\
\text { y Medical } \\
\text { Center }\end{array}$ & $\begin{array}{l}\text { CAUTI } \\
\text { bundle that } \\
\text { included } \\
\text { standardizing } \\
\text { the protocol } \\
\text { following } \\
\text { guidelines } \\
\text { form } \\
\text { Healthcare } \\
\text { Infection } \\
\text { Control } \\
\text { Practices } \\
\text { Advisory } \\
\text { Committee, } \\
\text { and nurse- } \\
\text { driven } \\
\text { protocol }\end{array}$ & $\begin{array}{l}\text { Plan-Do- } \\
\text { Study-Act } \\
\text { Framewor } \\
\text { k }\end{array}$ & $\begin{array}{l}\text { After CAUTI } \\
\text { bundle } \\
\text { intervention } \\
\text { was } \\
\text { implemented } \\
\text { and a there } \\
\text { was a decline } \\
\text { in IUC } \\
\text { device days } \\
\text { and a number } \\
\text { of CAUTIs }\end{array}$ & $\begin{array}{l}\text { Since } \\
\text { implementati } \\
\text { on of CAUTI } \\
\text { bundle, } \\
\text { compliance } \\
\text { with every } \\
\text { intervention } \\
\text { has been } \\
\text { steadily } \\
\text { increasing. } \\
\text { Compliance } \\
\text { increased to } \\
\text { a 94\%. The } \\
\text { steady } \\
\text { decline in } \\
\text { urinary } \\
\text { catheter- } \\
\text { device days } \\
\text { and actual } \\
\text { number of } \\
\text { CAUTIs } \\
\text { were a true } \\
\text { indicator of } \\
\text { success for } \\
\text { this project. }\end{array}$ \\
\hline $\begin{array}{l}\text { Taha, H., Raji, S. J., Khallaf, A., Abu } \\
\text { Hija, S., Mathew, R., Rashed, H., Du } \\
\text { Plessis, C., Allie, Z., } \\
\text { Ellahham, S. (2017). Improving } \\
\text { catheter associated urinary tract }\end{array}$ & $\begin{array}{l}\text { To find learn } \\
\text { if } \\
\text { implementati } \\
\text { on the } \\
\text { following }\end{array}$ & $\begin{array}{l}\text { Process } \\
\text { Improveme } \\
\text { nt } \\
\text { Prospective } \\
\text { Study }\end{array}$ & $\begin{array}{l}\text { Project } \\
\text { was piloted } \\
\text { in medical } \\
\text { units. After } \\
\text { positive }\end{array}$ & $\begin{array}{l}\text { CAUTI } \\
\text { prevention } \\
\text { strategies } \\
\text { have been } \\
\text { developed, }\end{array}$ & None & $\begin{array}{l}\text { This } \\
\text { performance } \\
\text { improvement } \\
\text { project } \\
\text { demonstrated }\end{array}$ & $\begin{array}{l}\text { The } \\
\text { multidiscipli } \\
\text { nary team } \\
\text { managed to } \\
\text { implement }\end{array}$ \\
\hline
\end{tabular}




\begin{tabular}{|c|c|c|c|c|c|c|}
\hline $\begin{array}{l}\text { infection rates in the medical units. } \\
\text { BMJ Quality Improvement Reports, } \\
6(1) \text {. } \\
\text { https://doi.org/10.1136/bmjquality. } \\
\text { u209593.w7966 }\end{array}$ & $\begin{array}{l}\text { CAUTI } \\
\text { prevention } \\
\text { bundle } \\
\text { decreases } \\
\text { CAUTIs } \\
\text { rates: (1) } \\
\text { Standardizin } \\
\text { g urinary } \\
\text { catheter } \\
\text { insertion and } \\
\text { maintenance } \\
\text { bundles } \\
\text { based on EB } \\
\text { guidelines, } \\
\text { (2) Monitor } \\
\text { compliance } \\
\text { with catheter } \\
\text { bundles and } \\
\text { provide } \\
\text { feedback to } \\
\text { frontline } \\
\text { staff, (3) } \\
\text { Education } \\
\text { awareness } \\
\text { campaigns } \\
\text { and periodic } \\
\text { in-service } \\
\text { competency } \\
\text { to frontline } \\
\text { staff, (4) } \\
\text { Coaching by } \\
\text { clinical } \\
\text { resources } \\
\text { nursed and } \\
\text { infection }\end{array}$ & $\begin{array}{l}\text { Level } 1 \\
\text { Grade A }\end{array}$ & $\begin{array}{l}\text { results the } \\
\text { CAUTI } \\
\text { prevention } \\
\text { bundle was } \\
\text { disseminat } \\
\text { ed } \\
\text { throughout } \\
\text { the } \\
\text { hospital. }\end{array}$ & $\begin{array}{l}\text { implemented } \\
\text {, and } \\
\text { validated } \\
\text { evaluated } \\
\text { through a } \\
\text { series of } \\
\text { performance } \\
\text { improvement } \\
\text { methods. } \\
\text { Following } \\
\text { the National } \\
\text { Healthcare } \\
\text { Safety } \\
\text { Network } \\
\text { Guideline } \\
\text { (NHSN, } \\
\text { 2015), the } \\
\text { data was } \\
\text { extracted } \\
\text { from the } \\
\text { electronic } \\
\text { medical } \\
\text { record and } \\
\text { reported } \\
\text { monthly by } \\
\text { the infection } \\
\text { control team. } \\
\text { As a result of } \\
\text { these } \\
\text { interventions } \\
\text {, Urinary } \\
\text { Catheter } \\
\text { Workflow } \\
\text { was } \\
\text { developed } \\
\text { and }\end{array}$ & $\begin{array}{l}\text { that } \\
\text { implementin } \\
\text { g the CAUTI } \\
\text { prevention } \\
\text { bundle } \\
\text { significantly } \\
\text { decreased } \\
\text { CAUTI rates } \\
\text { in medical } \\
\text { units. } \\
\text { CAUTI rates } \\
\text { reduced from } \\
6.8 \text { per } 1000- \\
\text { unit days. }\end{array}$ & $\begin{array}{l}\text { EBP } \\
\text { interventions } \\
\text { and change } \\
\text { management } \\
\text { strategies } \\
\text { that resulted } \\
\text { in significant } \\
\text { sustained } \\
\text { reduction in } \\
\text { CAUTI rates } \\
\text { in the } \\
\text { medical } \\
\text { units. The } \\
\text { authors } \\
\text { recommende } \\
\text { d the CAUTI } \\
\text { prevention } \\
\text { bundle as } \\
\text { method to } \\
\text { decrease } \\
\text { CAUTI } \\
\text { rates. The } \\
\text { interventions } \\
\text { implemented } \\
\text { are } \\
\text { generalizable } \\
\text { and can be } \\
\text { replicated in } \\
\text { other units. } \\
\text { This EBP } \\
\text { project } \\
\text { enhanced } \\
\text { safety and } \\
\text { reduced } \\
\text { preventable }\end{array}$ \\
\hline
\end{tabular}




\begin{tabular}{|c|c|c|c|c|c|c|c|}
\hline & $\begin{array}{l}\text { control } \\
\text { links. }\end{array}$ & & & $\begin{array}{l}\text { implemented } \\
\text {, resulting in } \\
\text { a continuous } \\
\text { improvement } \\
\text { in CAUTI } \\
\text { rates to zero. }\end{array}$ & & & $\begin{array}{l}\text { harm from } \\
\text { CAUTI. }\end{array}$ \\
\hline $\begin{array}{l}\text { Yatim, J., Wong, K. S., Ling, M. L., } \\
\text { Tan, S. B., Tan, K. Y., \& } \\
\text { Hockenberry, M. (2016). A nurse- } \\
\text { driven process for timely removal of } \\
\text { urinary catheters. International } \\
\text { Journal of Urological Nursing, 10(3), } \\
\text { 167-172. } \\
\text { https://doi.org/10.7257/1053- } \\
\text { 816X.2016.36.5.243 }\end{array}$ & $\begin{array}{l}\text { To find out } \\
\text { the } \\
\text { effectiveness } \\
\text { of a nurse- } \\
\text { driven } \\
\text { urinary } \\
\text { catheter } \\
\text { removal } \\
\text { using the } \\
\text { HOUDINI } \\
\text { process. }\end{array}$ & $\begin{array}{l}\text { Retrospecti } \\
\text { ve Process } \\
\text { Improveme } \\
\text { nt } \\
\text { Prospective } \\
\text { Study } \\
\text { Level } 1 \\
\text { Grade A }\end{array}$ & $\begin{array}{l}\text { N-75 } \\
\text { acute } \\
\text { tertiary } \\
\text { care } \\
\text { hospital } \\
\text { Medical } \\
\text { units with } \\
\text { various } \\
\text { medical } \\
\text { conditions. }\end{array}$ & $\begin{array}{l}\text { HOUDINI } \\
\text { provided a } \\
\text { structure for } \\
\text { nurse } \\
\text { decision- } \\
\text { making, } \\
\text { empowering } \\
\text { nursing staff } \\
\text { to do the } \\
\text { right thing. A } \\
\text { project- } \\
\text { planning } \\
\text { committee, } \\
\text { multimodal } \\
\text { communicati } \\
\text { on, } \\
\text { organization } \\
\text { al support } \\
\text { and the } \\
\text { successful } \\
\text { use of } \\
\text { provider } \\
\text { input to } \\
\text { enhance the } \\
\text { adoption } \\
\text { process are } \\
\text { essential } \\
\text { strategies for } \\
\text { achieving } \\
\text { progress. }\end{array}$ & None & $\begin{array}{l}\text { While the } \\
89 \% \\
\text { compliance } \\
\text { rate was } \\
\text { adequate by } \\
\text { using the } \\
\text { HOUDINI } \\
\text { method, this } \\
\text { research did } \\
\text { not analyze } \\
\text { variables } \\
\text { such as } \\
\text { overall unit } \\
\text { goals, unit } \\
\text { culture, } \\
\text { categories of } \\
\text { patients and } \\
\text { demographic } \\
\text { s of staff that } \\
\text { may affect } \\
\text { the } \\
\text { implementati } \\
\text { on of } \\
\text { procedures } \\
\text { such as the } \\
\text { nurse-driven } \\
\text { technique. In } \\
\text { order to get a } \\
\text { better } \\
\text { understandin }\end{array}$ & $\begin{array}{l}\text { HOUDINI } \\
\text { raised } \\
\text { awareness } \\
\text { among } \\
\text { nurses about } \\
\text { the need for } \\
\text { routine } \\
\text { patient } \\
\text { evaluation } \\
\text { for the } \\
\text { prompt } \\
\text { removal of } \\
\text { catheters } \\
\text { when there is } \\
\text { no longer a } \\
\text { clinical need } \\
\text { for them. } \\
\text { Our } \\
\text { experience } \\
\text { with this } \\
\text { project } \\
\text { showed that } \\
\text { the adoption } \\
\text { and use by } \\
\text { individuals' } \\
\text { nurses and } \\
\text { units of care } \\
\text { protocols or } \\
\text { algorithms } \\
\text { for nursing }\end{array}$ \\
\hline
\end{tabular}




\begin{tabular}{|c|c|c|c|c|c|c|c|}
\hline & & & & & & $\begin{array}{l}g \text { of these } \\
\text { variables and } \\
\text { their effect } \\
\text { on } \\
\text { compliance } \\
\text { levels, } \\
\text { further work } \\
\text { is required. }\end{array}$ & $\begin{array}{l}\text { care was } \\
\text { better } \\
\text { accomplishe } \\
\text { d with } \\
\text { feedback and } \\
\text { effective } \\
\text { communicati } \\
\text { on. }\end{array}$ \\
\hline $\begin{array}{l}\text { Zurmehly, J. (2018). Implementing a } \\
\text { nurse-driven protocol to reduce } \\
\text { catheter-associated urinary tract } \\
\text { infections in a long-term acute care } \\
\text { hospital. The Journal of Continuing } \\
\text { Education in Nursing, } 49(8): 372- \\
377 \text {. } \\
\text { https://doi.org/10.3928/00220124- } \\
\text { 20180718-08 }\end{array}$ & $\begin{array}{l}\text { To find out } \\
\text { if the } \\
\text { implementati } \\
\text { on of an } \\
\text { education } \\
\text { program to } \\
\text { carry out a } \\
\text { newly EB- } \\
\text { urinary } \\
\text { catheter } \\
\text { protocol } \\
\text { reduces } \\
\text { CAUTIs in } \\
\text { long-term } \\
\text { acute care } \\
\text { hospital } \\
\text { (LTACH). }\end{array}$ & $\begin{array}{l}\text { A pre-and } \\
\text { post-quasi- } \\
\text { experiment } \\
\text { al } \\
\text { evidence- } \\
\text { based } \\
\text { practice } \\
\text { project } \\
\text { Level } 1 \\
\text { Grade A }\end{array}$ & $\begin{array}{l}\text { Nurses } \\
\text { across } \\
\text { three units } \\
\text { in a large } \\
\text { LTACH } \\
\text { N-70 }\end{array}$ & $\begin{array}{l}\text { Implemented } \\
\text { a prevention } \\
\text { education } \\
\text { program } \\
\text { outlining a } \\
\text { new } \\
\text { standardized } \\
\text { protocol flow } \\
\text { chart } \\
\text { highlighting } \\
\text { catheter } \\
\text { awareness } \\
\text { and } \\
\text { prevention } \\
\text { on CAUTIs } \\
\text { to all nurses. } \\
\text { The EB } \\
\text { educational } \\
\text { protocol on } \\
\text { catheter care } \\
\text { was } \\
\text { implemented } \\
\text { and the } \\
\text { results of it } \\
\text { was } \\
\text { measured } \\
\text { with a } \\
\text { pretest- }\end{array}$ & $\begin{array}{l}\text { Iowa } \\
\text { model of } \\
\text { EBP }\end{array}$ & $\begin{array}{l}\text { A totally } \\
\text { urinary } \\
\text { catheter days } \\
\text { decreased by } \\
10.1 \% \text { after } \\
\text { the } \\
\text { intervention } \\
\text { in education, } \\
\text { and the rate } \\
\text { of CAUTI } \\
\text { decreased by } \\
74 \% \text { (4.82 } \\
\text { CAUTI per } \\
1,000 \text { patient } \\
\text { days } 1.24) \text {. } \\
\text { The absolute } \\
\text { reduction in } \\
\text { risk per } \\
1,000 \\
\text { catheter-days } \\
\text { was } 3.58 \\
\text { infections }\end{array}$ & $\begin{array}{l}\text { Significant } \\
\text { reductions } \\
\text { were } \\
\text { observed in } \\
\text { total } \\
\text { catheter- } \\
\text { days, and } \\
\text { CAUTI rates } \\
\text { improved in } \\
\text { an LTACH } \\
\text { following } \\
\text { implementati } \\
\text { on of an } \\
\text { education } \\
\text { program and } \\
\text { evidence- } \\
\text { based } \\
\text { urinary } \\
\text { catheter } \\
\text { protocol. The } \\
\text { authors } \\
\text { recommend } \\
\text { the new } \\
\text { standardized } \\
\text { protocol that } \\
\text { outlines key } \\
\text { treatment } \\
\text { methods for }\end{array}$ \\
\hline
\end{tabular}




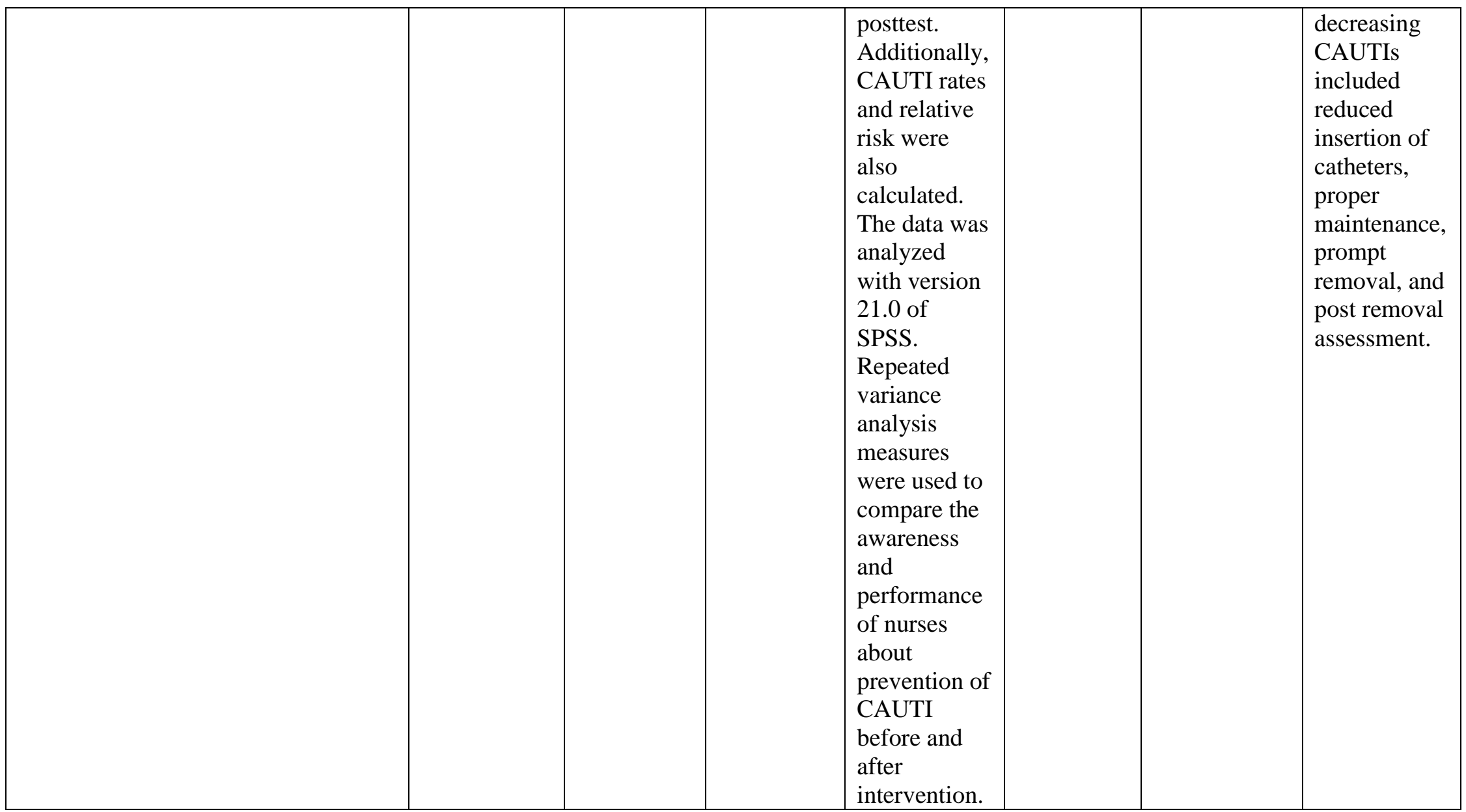

Note: Catheter-associated urinary tract infection (CAUTI), indwelling urinary catheter (IUC) 


\section{Appendix B}

\section{Summary of Systematic Reviews (SR)}

\begin{tabular}{|c|c|c|c|c|c|c|c|}
\hline Citation & $\begin{array}{l}\text { Quality } \\
\text { Grade }\end{array}$ & Question & Search Strategy & $\begin{array}{l}\text { Inclusion/ } \\
\text { Exclusion Criteria }\end{array}$ & $\begin{array}{l}\text { Data Extraction } \\
\text { and Analysis }\end{array}$ & Key Findings & $\begin{array}{l}\text { Usefulness/Reco } \\
\text { mmendation/ } \\
\text { Implications }\end{array}$ \\
\hline $\begin{array}{l}\text { Durant, D. J. } \\
\text { (2017). Nurse- } \\
\text { driven protocols } \\
\text { and the prevention } \\
\text { of catheter- } \\
\text { associated urinary } \\
\text { tract infections: A } \\
\text { systematic review. } \\
\text { American Journal } \\
\text { of Infection } \\
\text { Control, } 45(12), \\
1331-1341 . \\
\text { https://doi.org/10.1 } \\
\text { 016j.ajic. }\end{array}$ & $\begin{array}{l}\text { Level } 2 \\
\text { Grade B }\end{array}$ & $\begin{array}{l}\text { Does a nurse- } \\
\text { driven protocol } \\
\text { facilitate } \\
\text { appropriate } \\
\text { catheter use and } \\
\text { timely removal to } \\
\text { prevent } \\
\text { CAUTIs? }\end{array}$ & $\begin{array}{l}\text { With } \\
\text { recommendations } \\
\text { from the Institute } \\
\text { of Medicine, a } \\
\text { systematic review } \\
\text { of studies } \\
\text { published in the } \\
\text { United States } \\
\text { since } 2006 \text { was } \\
\text { conducted. } \\
\text { Databases } \\
\text { included } \\
\text { CINAHL, } \\
\text { Medline, Health } \\
\text { Source: Nursing } \\
\text { Academic, and } \\
\text { Science Direct. } \\
\text { Hand-searching } \\
\text { was also } \\
\text { completed, and } \\
\text { authors consulted } \\
\text { with clinical } \\
\text { experts. Clinical } \\
\text { indicators and } \\
\text { CAUTI } \\
\text { occurrence were } \\
\text { investigated and } \\
\text { qualitatively } \\
\text { synthesized; } \\
\text { outcome } \\
\text { variability made } \\
\text { enable a statistical }\end{array}$ & $\begin{array}{l}\text { Inclusion criteria: } \\
\text { Articles published } \\
\text { after } 2006 \text { to } 2016 \\
\text { that investigated the } \\
\text { effect of a nurse- } \\
\text { driven intervention } \\
\text { on clinical outcomes } \\
\text { such as IUC } \\
\text { utilization levels, } \\
\text { IUC days and } \\
\text { CAUTI rates } \\
\text { (Results) of CAUTI- } \\
\text { related acute care } \\
\text { patients in the } \\
\text { United States } \\
\text { (population) were } \\
\text { measured compared } \\
\text { to previous } \\
\text { experience } \\
\text { (comparison). } \\
\text { Exclusion criteria: } \\
\text { Editorials and } \\
\text { opinion pieces were } \\
\text { excluded and not } \\
\text { analyzed }\end{array}$ & $\begin{array}{l}\text { The data was } \\
\text { extracted by author } \\
\text { and an independent } \\
\text { subject expert on } \\
\text { the topic. The } \\
\text { articles were } \\
\text { examined and } \\
\text { screened by title } \\
\text { and Web sites. } \\
\text { Qualitative review } \\
\text { of the collected } \\
\text { data was } \\
\text { performed, with } \\
\text { details outlined in } \\
\text { an evidence-based } \\
\text { table describing } \\
\text { geography, and } \\
\text { settings; } \\
\text { populations, } \\
\text { interventions, and } \\
\text { time period; } \\
\text { outcomes } \\
\text { measures; and } \\
\text { results. The author } \\
\text { did mention some } \\
\text { of the articles } \\
\text { found and reviewed } \\
\text { displayed some } \\
\text { variances of } \\
\text { outcomes and } \\
\text { methods used that } \\
\text { indicated an } \\
\end{array}$ & $\begin{array}{l}\text { The systematic review } \\
\text { revealed the } \\
\text { effectiveness of } \\
\text { implementing a nurse- } \\
\text { driven protocol that } \\
\text { can promote } \\
\text { appropriate catheter } \\
\text { use and timely } \\
\text { removal that will } \\
\text { decrease CAUTIs. } \\
\text { Multiple studies } \\
\text { demonstrated that the } \\
\text { implementation of a } \\
\text { checklist for IUC } \\
\text { medical needs and } \\
\text { assessment of removal } \\
\text { of catheter by nursing } \\
\text { if no longer indicated } \\
\text { has urinary catheter } \\
\text { UR decreased by } \\
50.2 \% \text {, from } 0.223 \text { to } \\
0.112 ; \text { equivalent to a } \\
4.1 \% \text { reduction in } \\
\text { catheter use per } \\
\text { month } \\
\end{array}$ & $\begin{array}{l}\text { Multiple studies } \\
\text { recommend the } \\
\text { implementing a } \\
\text { nurse-driven } \\
\text { protocol that can } \\
\text { decrease } \\
\text { CAUTIs. The } \\
\text { author states that } \\
\text { there is a need to } \\
\text { improve the study } \\
\text { design of EBP } \\
\text { projects } \\
\text { conducted within } \\
\text { the patient care } \\
\text { environment. } \\
\end{array}$ \\
\hline
\end{tabular}




\begin{tabular}{|c|c|c|c|c|c|c|c|}
\hline Citation & $\begin{array}{l}\text { Quality } \\
\text { Grade }\end{array}$ & Question & Search Strategy & $\begin{array}{l}\text { Inclusion/ } \\
\text { Exclusion Criteria }\end{array}$ & $\begin{array}{l}\text { Data Extraction } \\
\text { and Analysis }\end{array}$ & Key Findings & $\begin{array}{l}\text { Usefulness/Reco } \\
\text { mmendation/ } \\
\text { Implications }\end{array}$ \\
\hline & & & $\begin{array}{l}\text { meta-analysis } \\
\text { inappropriate. Key } \\
\text { words and phrases } \\
\text { used: Nurse- } \\
\text { driven, nurse- } \\
\text { directed, nurse } \\
\text { managed, } \\
\text { protocol, } \\
\text { intervention, and } \\
\text { catheter }\end{array}$ & & $\begin{array}{l}\text { inappropriate meta- } \\
\text { analysis. }\end{array}$ & & \\
\hline $\begin{array}{l}\text { Fonseca V. L., \& } \\
\text { Veludo F. A. } \\
\text { (2016). Prevention } \\
\text { of catheter- } \\
\text { associated urinary } \\
\text { tract infection: } \\
\text { implementation } \\
\text { strategies of } \\
\text { international } \\
\text { guidelines. Revista } \\
\text { Latino-Americana } \\
\text { De Enfermagem } \\
\text { (RLAE), 24, 1-9. } \\
\text { https://doi.org } \\
\text { doi:10.1590/1518- } \\
\text { 8345.0963.2678 }\end{array}$ & $\begin{array}{l}\text { Level 1 } \\
\text { Grade A }\end{array}$ & $\begin{array}{l}\text { What are the } \\
\text { methods used by } \\
\text { healthcare } \\
\text { professionals to } \\
\text { incorporate the } \\
\text { Centers for } \\
\text { Control and } \\
\text { Prevention of } \\
\text { Disease (CDC) } \\
\text { guidelines for } \\
\text { CAUTI } \\
\text { prevention? }\end{array}$ & $\begin{array}{l}\text { The design of this } \\
\text { systematic } \\
\text { literature review } \\
\text { was based on the } \\
\text { CAUTI concept, } \\
\text { analysis of the } \\
\text { initial question, } \\
\text { description of } \\
\text { eligibility criteria, } \\
\text { collection of } \\
\text { article samples } \\
\text { and further studies } \\
\text { and discussion of } \\
\text { the findings. The } \\
\text { databases used } \\
\text { were CINAHL, } \\
\text { Nursing \& Allied } \\
\text { Health Collection, } \\
\text { Cochrane Plus } \\
\text { Collection, } \\
\text { MedicLatina, } \\
\text { Medline, } \\
\text { Academic Search } \\
\text { Complete, ACS- } \\
\text { American } \\
\text { Chemical Society, } \\
\text { Health Reference }\end{array}$ & $\begin{array}{l}\text { Inclusion criteria: } \\
\text { Publications from } \\
\text { January } 2007 \text { to } \\
\text { December 2014, } \\
\text { hospitalized patients } \\
\text { with catheters, and } \\
\text { primary studies with } \\
\text { quantitative } \\
\text { approach. } \\
\text { Exclusion criteria: } \\
\text { Patients with } \\
\text { chronic indwelling } \\
\text { catheters and } \\
\text { opinion studies, and } \\
\text { primary studies with } \\
\text { qualitative } \\
\text { approach. Another } \\
\text { exclusion was } \\
\text { studies that did not } \\
\text { provide enough } \\
\text { information on } \\
\text { criteria deemed } \\
\text { important for the } \\
\text { analysis; } \\
\text { participants, } \\
\text { procedures, and } \\
\end{array}$ & $\begin{array}{l}\text { Review of the } \\
\text { selected articles, } \\
\text { specifying each one } \\
\text { by author, year, } \\
\text { country, } \\
\text { participants, } \\
\text { interventions, } \\
\text { results, and design. } \\
\text { The findings were } \\
\text { reviewed and listed } \\
\text { in a table that } \\
\text { examined } 13 \text { high- } \\
\text { quality level of } \\
\text { evidence articles. } \\
\text { The authors } \\
\text { determined that the } \\
\text { results of the } \\
\text { studies were } \\
\text { analogous, despite } \\
\text { the differences in } \\
\text { methodology } \\
\text { applied. There was } \\
\text { an intervention } \\
\text { phase in most of } \\
\text { them, and a post- } \\
\text { intervention } \\
\text { process. }\end{array}$ & $\begin{array}{l}\text { Many research studies } \\
\text { encouraged the } \\
\text { training of nurses on } \\
\text { CAUTI's prevention } \\
\text { guidelines, which } \\
\text { were showed to be of } \\
\text { critical importance in } \\
\text { their duties. Based on } \\
\text { medical guidelines for } \\
\text { the prevention of } \\
\text { CAUTI, the nurses } \\
\text { were able to improve } \\
\text { the metrics of } \\
\text { indwelling catheters } \\
\text { and the need for a } \\
\text { catheter to remain in } \\
\text { place or to encourage } \\
\text { the removal of } \\
\text { catheters that were } \\
\text { deemed unnecessary }\end{array}$ & $\begin{array}{l}\text { Throughout the } \\
\text { studies, the } \\
\text { authors } \\
\text { recommended } \\
\text { implementation } \\
\text { of prevention } \\
\text { bundle. The } \\
\text { bundle includes a } \\
\text { protocol, } \\
\text { checklist or } \\
\text { algorithm to } \\
\text { identify the } \\
\text { clinical indication } \\
\text { for the catheter, } \\
\text { and using aseptic } \\
\text { technique during } \\
\text { insertion, } \\
\text { maintenance and } \\
\text { removal. Another } \\
\text { intervention } \\
\text { mentioned was } \\
\text { the early removal } \\
\text { of unnecessary } \\
\text { catheters } \\
\text { significantly } \\
\text { decreased } \\
\text { CAUTIs }\end{array}$ \\
\hline
\end{tabular}




\begin{tabular}{|c|c|c|c|c|c|c|c|}
\hline Citation & $\begin{array}{l}\text { Quality } \\
\text { Grade }\end{array}$ & Question & Search Strategy & $\begin{array}{l}\text { Inclusion/ } \\
\text { Exclusion Criteria }\end{array}$ & $\begin{array}{l}\text { Data Extraction } \\
\text { and Analysis }\end{array}$ & Key Findings & $\begin{array}{l}\text { Usefulness/Reco } \\
\text { mmendation/ } \\
\text { Implications }\end{array}$ \\
\hline & & & $\begin{array}{l}\text { Center Academic, } \\
\text { Nursing Reference } \\
\text { Center, } \\
\text { ScienceDirect } \\
\text { Journals, and } \\
\text { Wiley Online } \\
\text { Library. Key } \\
\text { terms used: } \\
\text { urinary, infection, } \\
\text { catheter, and } \\
\text { nursing. }\end{array}$ & $\begin{array}{l}\text { outcomes drawing } \\
\text { of from the report. }\end{array}$ & & & \\
\hline \begin{tabular}{|l|} 
Li, F., Song, M., \\
Xu, L, Deng, B., \\
Zhu, S., Li, X. \\
(2018). Risk \\
factors for catheter- \\
associated urinary \\
tract infection \\
among hospitalized \\
patients: A \\
systematic review \\
and meta-analysis \\
of observational \\
studies. Journal of \\
Advanced Nursing, \\
75:57-527. \\
https://doi.org/10.1 \\
111/jan. 13863
\end{tabular} & $\begin{array}{l}\text { Level } 2 \\
\text { Grade B } \\
\end{array}$ & $\begin{array}{l}\text { To identify the } \\
\text { risk factors for } \\
\text { CAUTIs in } \\
\text { hospitalized } \\
\text { patients }\end{array}$ & $\begin{array}{l}\text { The systematic- } \\
\text { review and meta- } \\
\text { analysis search } \\
\text { began with an } \\
\text { electronic search } \\
\text { that was } \\
\text { conducted by two } \\
\text { reviewers using } \\
\text { PubMed, } \\
\text { EMBASE, Web of } \\
\text { Science, and the } \\
\text { Cochrane } \\
\text { Database. Key } \\
\text { words used were } \\
\text { catheter- } \\
\text { associated urinary } \\
\text { tract infection, } \\
\text { urinary tract, } \\
\text { urinary catheter, } \\
\text { catheterization, } \\
\text { hospitalized, risk } \\
\text { factors, and } \\
\text { nursing. Other key } \\
\text { terms were meta- } \\
\text { analysis, nursing, } \\
\text { observational }\end{array}$ & $\begin{array}{l}\text { Inclusion criteria: } \\
\text { Studies published } \\
\text { between January } \\
\text { 2008 to January } \\
\text { 2018, and English } \\
\text { language } \\
\text { Exclusion criteria: } \\
\text { was non- English } \\
\text { articles } \\
\\
\end{array}$ & $\begin{array}{l}\text { The data was } \\
\text { extracted using a } \\
\text { standardized form. } \\
\text { The two reviewers } \\
\text { independently } \\
\text { extracted the data } \\
\text { from the articles } \\
\text { selected: first } \\
\text { author, publication } \\
\text { date, sample ages, } \\
\text { length of research, } \\
\text { departments, } \\
\text { population size, } \\
\text { comorbidities, risk } \\
\text { factors, incidence } \\
\text { related to CAUTI, } \\
\text { applicable } \\
\text { interventions and } \\
\text { outcomes. The data } \\
\text { was further } \\
\text { reviewed when } \\
\text { there were } \\
\text { inconsistencies } \\
\text { noted. }\end{array}$ & $\begin{array}{l}\text { Studies demonstrated } \\
\text { that the major risk } \\
\text { factors for catheter- } \\
\text { associated urinary } \\
\text { tract infections were } \\
\text { extended length of } \\
\text { catheterization, } \\
\text { female gender, } \\
\text { diabetes, prior } \\
\text { catheterizations, and } \\
\text { ICU days. Identifying } \\
\text { of risk factors can } \\
\text { lead to the } \\
\text { implementation of } \\
\text { interventions to } \\
\text { improve patient } \\
\text { outcomes. }\end{array}$ & $\begin{array}{l}\text { The } \\
\text { recommendation } \\
\text { was to further } \\
\text { investigate the } \\
\text { microbial isolates } \\
\text { and to focus on } \\
\text { CAUTI } \\
\text { interventions } \\
\text { strategies to } \\
\text { reduce incidence } \\
\text { and associated } \\
\text { mortality. } \\
\text { Multiple articles } \\
\text { mentioned the } \\
\text { need for nurses to } \\
\text { be aware of the } \\
\text { high risk for } \\
\text { CAUTIs and that } \\
\text { implementing a } \\
\text { standardized } \\
\text { protocol can } \\
\text { decrease CAUTIs } \\
\text { and improve } \\
\text { patient safety. }\end{array}$ \\
\hline
\end{tabular}




\begin{tabular}{|c|c|c|c|c|c|c|c|}
\hline Citation & $\begin{array}{l}\text { Quality } \\
\text { Grade }\end{array}$ & Question & Search Strategy & $\begin{array}{l}\text { Inclusion/ } \\
\text { Exclusion Criteria }\end{array}$ & $\begin{array}{l}\text { Data Extraction } \\
\text { and Analysis }\end{array}$ & Key Findings & $\begin{array}{l}\text { Usefulness/Reco } \\
\text { mmendation/ } \\
\text { Implications }\end{array}$ \\
\hline & & & $\begin{array}{l}\text { studies, risk } \\
\text { factors, and } \\
\text { systematic review. } \\
\text { The quality of the } \\
\text { articles was } \\
\text { assessed using the } \\
\text { Newcastle-Ottawa } \\
\text { Scale }\end{array}$ & & & & \\
\hline $\begin{array}{l}\text { Menegueti, M. G., } \\
\text { Ciol, M. A., } \\
\text { Bellissimo- } \\
\text { Rodrigues, F., } \\
\text { Auxiliadora- } \\
\text { Martins, M., } \\
\text { Gaspar, G. G., } \\
\text { Canini, S., Basile- } \\
\text { Filho, A., \& Laus, } \\
\text { A. M. (2019). } \\
\text { Long-term } \\
\text { prevention of } \\
\text { catheter-associated } \\
\text { urinary tract } \\
\text { infections among } \\
\text { critically ill } \\
\text { patients through } \\
\text { the implementation } \\
\text { of an educational } \\
\text { program and a } \\
\text { daily checklist for } \\
\text { maintenance of } \\
\text { indwelling urinary } \\
\text { catheters: A quasi- } \\
\text { experimental study. } \\
\text { Medicine, 98(8), } \\
\text { e14417. } \\
\text { https://doi.org/10.1 }\end{array}$ & $\begin{array}{l}\text { Level } 1 \\
\text { Grade A }\end{array}$ & $\begin{array}{l}\text { To find out } \\
\text { whether patients } \\
\text { undergoing } \\
\text { complete joint } \\
\text { arthroplasty } \\
\text { (TJA) need } \\
\text { urinary } \\
\text { catheterization. }\end{array}$ & $\begin{array}{l}\text { The meta-analysis } \\
\text { was conducted } \\
\text { based on the } \\
\text { Cochrane } \\
\text { Handbook for } \\
\text { Systematic } \\
\text { Intervention } \\
\text { prepared in } \\
\text { compliance with } \\
\text { the } \\
\text { recommendations } \\
\text { for the PRISMA } \\
\text { checklist. } \\
\text { Searches of } \\
\text { PubMed, } \\
\text { EMBASE, The } \\
\text { Web Science, the } \\
\text { Cochrane Library, } \\
\text { and the China } \\
\text { National } \\
\text { Knowledge } \\
\text { Infrastructure in } \\
\text { were } \\
\text { systematically } \\
\text { conducted up to } \\
\text { June } 2018 \text {. The } \\
\text { key words used } \\
\text { for this review } \\
\text { were total knee. }\end{array}$ & $\begin{array}{l}\text { Inclusion criteria: } \\
\text { meta-analysis } \\
\text { included the PICOS: } \\
\text { population, } \\
\text { intervention, } \\
\text { comparator, } \\
\text { outcome, and study } \\
\text { design. Meta- } \\
\text { analysis, } \\
\text { quantitative, and } \\
\text { qualitative articles } \\
\text { were included. } \\
\text { There were no } \\
\text { language or } \\
\text { geographical } \\
\text { restrictions. } \\
\text { Exclusion criteria: } \\
\text { Full-text articles } \\
\text { were excluded with } \\
\text { relevant reasons not } \\
\text { mentioned. }\end{array}$ & $\begin{array}{l}\text { Two reviewers } \\
\text { independently } \\
\text { examined the } \\
\text { studies' } \\
\text { methodological } \\
\text { strengths, using the } \\
\text { Cochrane } \\
\text { Systematic Review } \\
\text { Collaboration. The } \\
\text { seven items of } \\
\text { sequence } \\
\text { generation, } \\
\text { sequence allocation } \\
\text { concealment, } \\
\text { participant and } \\
\text { staff blinding, } \\
\text { results assessment } \\
\text { blinding, } \\
\text { incomplete out } \\
\text { data, selective } \\
\text { reporting and other } \\
\text { biases were } \\
\text { meaningful } \\
\text { indicators. }\end{array}$ & $\begin{array}{l}\text { The key findings were } \\
\text { that patients in the } \\
\text { indwelling catheter } \\
\text { groups had a higher } \\
\text { risk of urinary tract } \\
\text { infection compared to } \\
\text { patients in non- } \\
\text { indwelling catheter } \\
\text { groups. Furthermore, } \\
\text { there were no } \\
\text { significant differences } \\
\text { between the two } \\
\text { groups in terms of } \\
\text { urinary retention, } \\
\text { length of the } \\
\text { procedure, and the } \\
\text { length of hospital } \\
\text { stay. Additionally, } \\
\text { several articles } \\
\text { concluded there was } \\
\text { still no standard } \\
\text { protocol for the } \\
\text { implementation of the } \\
\text { indwelling catheter in } \\
\text { total joint } \\
\text { arthroplasty. } \\
\end{array}$ & $\begin{array}{l}\text { Based on the } \\
\text { current evidence, } \\
\text { this meta-analysis } \\
\text { has shown that } \\
\text { urinary } \\
\text { catheterization } \\
\text { during TJA may } \\
\text { increase } \\
\text { postoperative } \\
\text { urinary tract } \\
\text { infection and the } \\
\text { need for an } \\
\text { indwelling } \\
\text { catheter may not } \\
\text { be routinely } \\
\text { required for these } \\
\text { patients. The } \\
\text { recommendations } \\
\text { of this meta- } \\
\text { analysis are } \\
\text { implementation } \\
\text { of a standardized } \\
\text { of a protocol to } \\
\text { avoid the use of } \\
\text { indwelling } \\
\text { catheters in TJA } \\
\text { patients as } \\
\text { needed. }\end{array}$ \\
\hline
\end{tabular}


REDUCING CATHETER-ASSOCIATED URINARY TRACT INFECTION

74

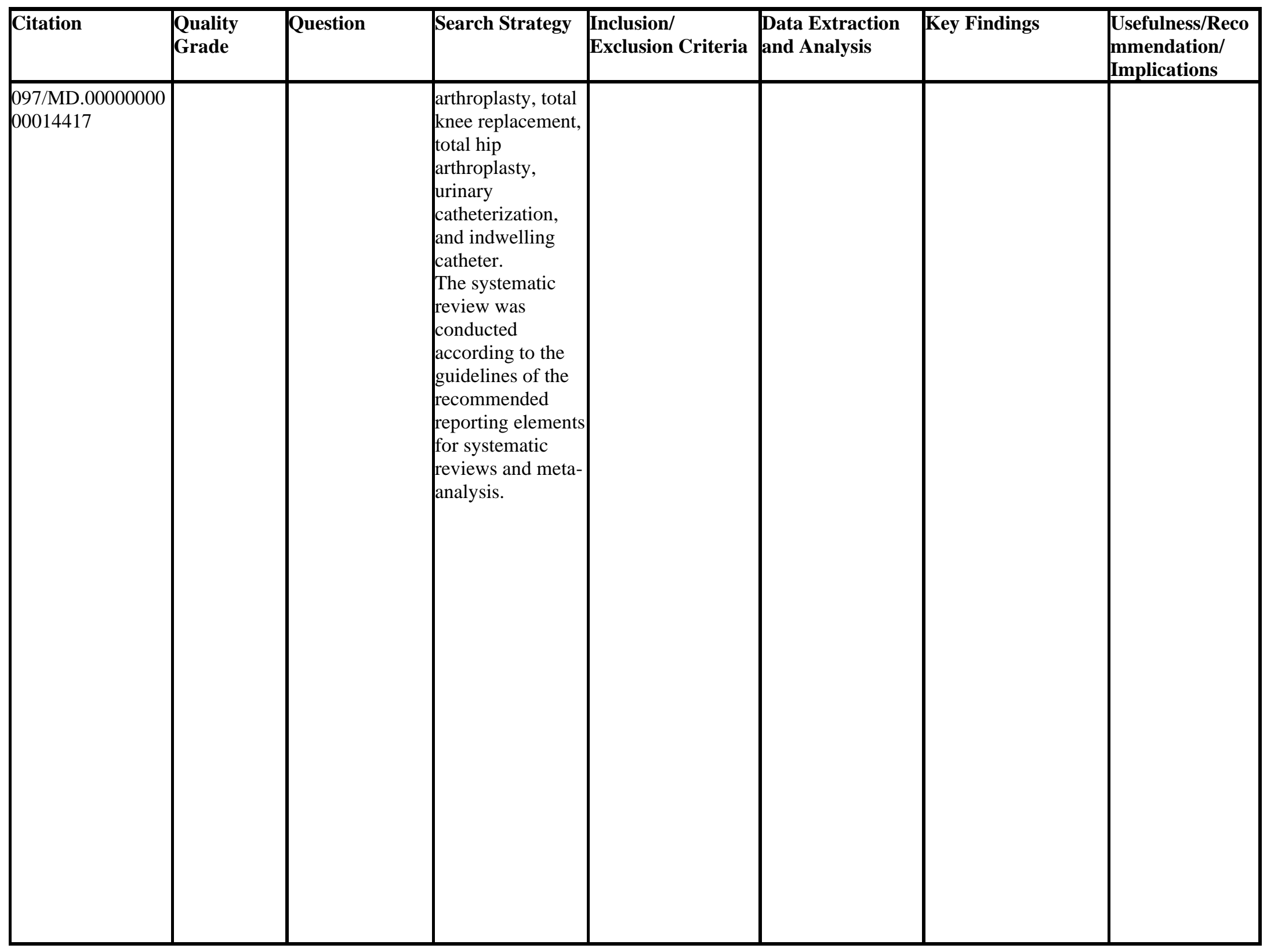




\begin{tabular}{|c|c|c|c|c|c|c|c|}
\hline Citation & $\begin{array}{l}\text { Quality } \\
\text { Grade }\end{array}$ & Question & Search Strategy & $\begin{array}{l}\text { Inclusion/ } \\
\text { Exclusion Criteria }\end{array}$ & $\begin{array}{l}\text { Data Extraction } \\
\text { and Analysis }\end{array}$ & Key Findings & $\begin{array}{l}\text { Usefulness/Reco } \\
\text { mmendation/ } \\
\text { Implications }\end{array}$ \\
\hline $\begin{array}{l}\text { Meddings, J., } \\
\text { Saint, S., Krein, S. } \\
\text { L., Gaies, E., } \\
\text { Reichert, H., } \\
\text { Hickner, A., } \\
\text { McNamara, S., } \\
\text { Mann, J.D., \& } \\
\text { Mody, L. (2017). } \\
\text { Systematic review } \\
\text { of interventions to } \\
\text { reduce urinary tract } \\
\text { infection in nursing } \\
\text { home residents. } \\
\text { Journal of Hospital } \\
\text { Medicine, 12(5), } \\
\text { 356. } \\
\text { https://doi.org/10.1 } \\
\text { 2788/jhm.2724 }\end{array}$ & \begin{tabular}{|l} 
Level 1 \\
Grade A \\
\end{tabular} & $\begin{array}{l}\text { To identify } \\
\text { interventions to } \\
\text { reduce UTIs }\end{array}$ & $\begin{array}{l}\text { The search } \\
\text { included Ovid } \\
\text { MEDLINE, } \\
\text { Cochrane Library, } \\
\text { CINAHL, Web of } \\
\text { Science and } \\
\text { Embase through } \\
\text { June } 22,2015 . \\
\text { Key terms used } \\
\text { were catheter- } \\
\text { associated } \\
\text { infections, UTI, } \\
\text { catheter- } \\
\text { associated urinary } \\
\text { tract infections, } \\
\text { urinary catheter, } \\
\text { nursing home, } \\
\text { long-term care, } \\
\text { and rehabilitation } \\
\text { units. }\end{array}$ & $\begin{array}{l}\text { Inclusion criteria: } \\
\text { English language, } \\
\text { included } \\
\text { randomized } \\
\text { controlled trials and } \\
\text { non-randomized } \\
\text { trials. } \\
\text { Exclusion criteria: } \\
\text { Full-text review, } \\
\text { observational and } \\
\text { retrospective studies } \\
\end{array}$ & $\begin{array}{l}\text { The following } \\
\text { information was } \\
\text { extracted: first } \\
\text { author, published } \\
\text { date, age, number } \\
\text { of participants, } \\
\text { interventions, } \\
\text { method, anesthesia, } \\
\text { criteria for urinary } \\
\text { retention and } \\
\text { outcome measures. } \\
\text { The statistical } \\
\text { analysis was } \\
\text { carried out using } \\
\text { the program } \\
\text { RevMan } 5 \text { (Version } \\
\text { 5.3, Cochrane } \\
\text { Collaboration, } \\
\text { UK). The results } \\
\text { were summarized } \\
\text { and listed in a } \\
\text { table. The two } \\
\text { researchers } \\
\text { independently } \\
\text { abstracted relevant } \\
\text { information } \\
\text { concerning the } \\
\text { study design, } \\
\text { participants, } \\
\text { inclusion, } \\
\text { exclusion criteria, } \\
\text { results, and quality } \\
\text { parameters. } \\
\text { Methodological } \\
\text { quality scores were } \\
\text { calculated using a } \\
\text { version of Downs }\end{array}$ & $\begin{array}{l}\text { Findings } \\
\text { demonstrated that the } \\
\text { following } \\
\text { interventions were } \\
\text { recommended to } \\
\text { decrease CAUTIs in } \\
\text { nursing homes, } \\
\text { rehabilitation units, } \\
\text { acute care facilities, } \\
\text { and hospitals: } \\
\text { *Limiting catheter } \\
\text { use. } \\
* \text { Promptly removing } \\
\text { catheters. }\end{array}$ & \begin{tabular}{|l} 
Evidence in this \\
meta-analysis \\
review \\
demonstrated that \\
catheters increase \\
UTIs in patients. \\
The avoidance of \\
catheters can \\
improve patient \\
outcomes, \\
decrease cost, \\
decrease hospital \\
stay, and improve \\
patient safety. \\
The studies \\
reviewed, \\
concluded that \\
implementation \\
of multiple \\
interventions can \\
decrease CAUTIs \\
significantly. \\
*Insert urinary \\
catheter only \\
when clinically \\
indicated. \\
*Insert using \\
aseptic technique. \\
* Remove catheter \\
as soon as \\
clinically \\
indicated
\end{tabular} \\
\hline
\end{tabular}




\begin{tabular}{|c|c|c|c|c|c|c|c|}
\hline Citation & $\begin{array}{l}\text { Quality } \\
\text { Grade }\end{array}$ & Question & Search Strategy & $\begin{array}{l}\text { Inclusion/ } \\
\text { Exclusion Criteria }\end{array}$ & $\begin{array}{l}\text { Data Extraction } \\
\text { and Analysis }\end{array}$ & Key Findings & $\begin{array}{l}\text { Usefulness/Reco } \\
\text { mmendation// } \\
\text { Implications }\end{array}$ \\
\hline & & & & & $\begin{array}{l}\text { and Black's } \\
\text { Quality Index } \\
\text { checklist } \\
\text { appropriate for } \\
\text { evaluating both } \\
\text { randomized and } \\
\text { non-randomized } \\
\text { healthcare } \\
\text { interventions } \\
\text { studies. Because of } \\
\text { the broad research } \\
\text { variability between } \\
\text { these trials with } \\
\text { respect to recorded } \\
\text { treatments and } \\
\text { results, outcome } \\
\text { data could not be } \\
\text { incorporated into } \\
\text { summary meta- } \\
\text { analysis measures } \\
\text { to provide } \\
\text { aggregate estimates } \\
\text { of treatments } \\
\text { effects. }\end{array}$ & & \\
\hline \begin{tabular}{|l|} 
Reisinger, J. D., \\
Wojcik, A., \\
Jenkins, I., Edson, \\
B., Pegues, D. A., \\
\& Greene, L. \\
(2017). The project \\
protects infection \\
prevention \\
fellowship: A \\
model for \\
advancing infection \\
prevention \\
competency,
\end{tabular} & $\begin{array}{l}\text { Level } 2 \\
\text { Grade B }\end{array}$ & \begin{tabular}{|l|} 
To describe \\
epidemiology \\
and identify \\
practical \\
recommendations \\
in a succinct \\
format to help \\
acute care \\
hospitals enforce \\
their CAUTI \\
prevention \\
efforts and \\
prioritize them.
\end{tabular} & $\begin{array}{l}\text { A narrative review } \\
\text { was conducted of } \\
\text { the studies. The } \\
\text { review used a } \\
\text { three-step search } \\
\text { method. The } \\
\text { search was } \\
\text { conducted using } \\
\text { PubMed, Medline, } \\
\text { Google Scholar, } \\
\text { Medline, and } \\
\text { CINAHL, } \\
\text { followed by an }\end{array}$ & $\begin{array}{l}\text { Inclusion criteria: } \\
\text { English language } \\
\text { only, peer-reviewed, } \\
\text { studies published } \\
\text { between } 1999 \text { to } \\
2018 \text { and studies to } \\
\text { include at least one } \\
\text { related outcome. It } \\
\text { also included meta- } \\
\text { analysis, } \\
\text { quantitative, and } \\
\text { qualitative articles. }\end{array}$ & $\begin{array}{l}\text { The data was } \\
\text { extracted } \\
\text { independently by } \\
\text { two reviewers. Any } \\
\text { differences } \\
\text { between the two } \\
\text { researchers were } \\
\text { addressed by } \\
\text { discussion. The } \\
\text { statistical analysis } \\
\text { was a completion } \\
\text { of quality } \\
\text { evaluation, data }\end{array}$ & $\begin{array}{l}\text { Reports from several } \\
\text { studies indicated that } \\
\text { nosocomial UTIs } \\
\text { hinder the progression } \\
\text { of patients admitted to } \\
\text { ICU units. However, } \\
\text { since nosocomial } \\
\text { UTIs, which are } \\
\text { important causes of } \\
\text { morbidity in ICU } \\
\text { patients are difficult } \\
\text { to diagnose and treat. } \\
\text { Furthermore, efforts }\end{array}$ & $\begin{array}{l}\text { The review } \\
\text { recommends } \\
\text { further studies } \\
\text { that support } \\
\text { current } \\
\text { management } \\
\text { strategies to } \\
\text { address CAUTIs. } \\
\text { However, several } \\
\text { studies confirmed } \\
\text { that reducing } \\
\text { indwelling } \\
\text { catheter use }\end{array}$ \\
\hline
\end{tabular}




\begin{tabular}{|c|c|c|c|c|c|c|c|}
\hline Citation & $\begin{array}{l}\text { Quality } \\
\text { Grade }\end{array}$ & Question & Search Strategy & $\begin{array}{l}\text { Inclusion/ } \\
\text { Exclusion Criteria }\end{array}$ & $\begin{array}{l}\text { Data Extraction } \\
\text { and Analysis }\end{array}$ & Key Findings & $\begin{array}{l}\text { Usefulness/Reco } \\
\text { mmendation/ } \\
\text { Implications }\end{array}$ \\
\hline $\begin{array}{l}\text { quality } \\
\text { improvement, and } \\
\text { patient safety. } \\
\text { American Journal } \\
\text { of Infection } \\
\text { Control, } 45(8), \\
\text { 876-882. } \\
\text { https://doi.org/10.1 } \\
\text { 016/j.ajic.2017.03. } \\
\text { 031 }\end{array}$ & & & $\begin{array}{l}\text { evaluation of the } \\
\text { text words } \\
\text { contained in the } \\
\text { title and abstract, } \\
\text { and the index } \\
\text { terms used to } \\
\text { describe the } \\
\text { article. Key words } \\
\text { included } \\
\text { epidemiology of } \\
\text { nosocomial } \\
\text { infections } \\
\text { intensive care } \\
\text { unit, and hospital- } \\
\text { acquired infection. }\end{array}$ & $\begin{array}{l}\text { Exclusion criteria: } \\
\text { Studies that } \\
\text { included other } \\
\text { nosocomial } \\
\text { infections were } \\
\text { excluded. }\end{array}$ & $\begin{array}{l}\text { extraction, and } \\
\text { review of all } \\
\text { included studies. } \\
\text { Results of analyzed } \\
\text { articles were listed } \\
\text { in a table. }\end{array}$ & $\begin{array}{l}\text { need to be made to } \\
\text { prevent CAUTIs in } \\
\text { the ICU. Additionally, } \\
\text { the review } \\
\text { recommends } \\
\text { identifying risks and } \\
\text { implementing } \\
\text { standardized } \\
\text { interventions to } \\
\text { reduce CAUTIs in } \\
\text { ICU. }\end{array}$ & \begin{tabular}{|l} 
decreases \\
CAUTIs and the \\
complications \\
that the urinary \\
catheter causes. \\
For example, pain \\
and immobility. \\
While some \\
studies \\
recommend the \\
need to identify \\
the risk factors \\
and implement \\
interventions to \\
reduce the rates \\
of CAUTIs.
\end{tabular} \\
\hline $\begin{array}{l}\text { Schreiber, P. W., } \\
\text { Sax, H., } \\
\text { Wolfensberger, A., } \\
\text { Clack, L., \& } \\
\text { Kuster, S. P. } \\
\text { (2018). The } \\
\text { preventable } \\
\text { proportion of } \\
\text { healthcare- } \\
\text { associated } \\
\text { infections 2005- } \\
\text { 2016: Systematic } \\
\text { review and meta- } \\
\text { analysis. Infection } \\
\text { Control \& Hospital } \\
\text { Epidemiology, } \\
\text { 39(11), 1277-1295. }\end{array}$ & \begin{tabular}{|l} 
Level 1 \\
Grade A \\
\end{tabular} & $\begin{array}{l}\text { To identify } \\
\text { interventions to } \\
\text { reduce UTIs. }\end{array}$ & $\begin{array}{l}\text { A systematic } \\
\text { review and meta- } \\
\text { analysis were } \\
\text { performed on an } \\
\text { electronic search } \\
\text { of OVID Medline, } \\
\text { EBMASE, } \\
\text { CINAHL, } \\
\text { PubMed, and The } \\
\text { Cochrane library } \\
\text { for articles } \\
\text { published between } \\
\text { 2005 to 2016 } \\
\text { investigating } \\
\text { multifaceted } \\
\text { approaches to } \\
\text { minimize urinary } \\
\text { tract infections } \\
\text { (CAUTIs) } \\
\text { associated with } \\
\text { catheters. The }\end{array}$ & $\begin{array}{l}\text { Publications } \\
\text { between } 2005 \text { to } \\
2016 \text { assessing } \\
\text { multifaceted } \\
\text { interventions to } \\
\text { reduce CAUTIs and } \\
\text { English language } \\
\text { only. } \\
\text { Exclusion criteria: } \\
\text { Pediatrics, no } \\
\text { control groups, and } \\
\text { non-English articles. }\end{array}$ & $\begin{array}{l}\text { Two authors } \\
\text { individually } \\
\text { collected the data } \\
\text { from published } \\
\text { reports. The } \\
\text { extraction of data } \\
\text { was done using } \\
\text { standardized form } \\
\text { of data collection. } \\
\text { The reviewers also } \\
\text { collected data on } \\
\text { design population } \\
\text { and setting of the } \\
\text { sample, evaluated, } \\
\text { and measure of the } \\
\text { outcome. No data } \\
\text { processing was } \\
\text { conducted for } \\
\text { studies } \\
\text { documenting only } \\
\text { aggregated data, } \\
\end{array}$ & $\begin{array}{l}\text { All studies reviewed } \\
\text { demonstrated that a } \\
\text { CAUTI bundle can } \\
\text { decrease infections. } \\
\text { The following } \\
\text { Interventions } \\
\text { identified: } \\
\text { *Aseptic catheter } \\
\text { insertion, } \\
\text { maintenance, and } \\
\text { removal practices } \\
\text { *Observation of } \\
\text { catheter insertion } \\
\text { *Catheter indication } \\
\text { list, CAUTI bundle, } \\
\text { checklist, and training } \\
\text { *Education on } \\
\text { indwelling catheters, } \\
\text { mandatory prompts } \\
\text { and reminders in the }\end{array}$ & \begin{tabular}{|l} 
Multiple studies \\
recommend the \\
infection control \\
bundle that can \\
decrease \\
CAUTIs. The \\
bundle includes: \\
Insertion of \\
catheter only \\
when indicated \\
(Indication list). \\
*Removal when \\
unnecessary \\
*Alternatives \\
when appropriate \\
*Use small \\
catheters when \\
possible. \\
*Use aseptic \\
technique during \\
catheter insertion,
\end{tabular} \\
\hline
\end{tabular}




\begin{tabular}{|c|c|c|c|c|c|c|c|}
\hline Citation & $\begin{array}{l}\text { Quality } \\
\text { Grade }\end{array}$ & Question & Search Strategy & $\begin{array}{l}\text { Inclusion/ } \\
\text { Exclusion Criteria }\end{array}$ & $\begin{array}{l}\text { Data Extraction } \\
\text { and Analysis }\end{array}$ & Key Findings & $\begin{array}{l}\text { Usefulness/Reco } \\
\text { mmendation/ } \\
\text { Implications }\end{array}$ \\
\hline & & & $\begin{array}{l}\text { search strategy } \\
\text { was developed } \\
\text { with the assistance } \\
\text { of an experienced } \\
\text { librarian who has } \\
\text { expertise in } \\
\text { literature searches } \\
\text { for systematic } \\
\text { reviews and meta- } \\
\text { analyses. }\end{array}$ & & $\begin{array}{l}\text { without the } \\
\text { possibility of } \\
\text { estimating raw } \\
\text { numbers. The } \\
\text { authors estimated } \\
\text { the natural log of } \\
\text { the risk and } \\
\text { variance for studies } \\
\text { recording raw rates } \\
\text { in order to meta- } \\
\text { analyze the } \\
\text { retrieved data and } \\
\text { get pooled } \\
\text { estimates of the } \\
\text { risk ratio. The data } \\
\text { synthesis was } \\
\text { carried out using } \\
\text { STATA version } \\
\text { 11.1 (StataCorp, } \\
\text { College Station, } \\
\text { TX) software. The } \\
\text { results were } \\
\text { documented in a } \\
\text { table identifying } \\
\text { the most used } \\
\text { strategies to } \\
\text { effectively } \\
\text { decrease CAUTIs. }\end{array}$ & $\begin{array}{l}\text { electronic medical } \\
\text { record } \\
\text { *Daily patient } \\
\text { tracking } \\
\text { *Resident quality } \\
\text { champion } \\
\text { *Urine retention } \\
\text { protocol } \\
\text { *Urinary catheter } \\
\text { insertion kit and } \\
\text { mobile CT in neuro } \\
\text { ICU } \\
\text { *Nurse-generated } \\
\text { daily reminders used } \\
\text { by an intervention } \\
\text { team. } \\
\end{array}$ & $\begin{array}{l}\text { maintenance, and } \\
\text { removal. } \\
\text { *Use of aseptic } \\
\text { equipment and } \\
\text { supplies as } \\
\text { indicated. } \\
\text { *Appropriate } \\
\text { management of } \\
\text { catheter } \\
\text { *Maintain } \\
\text { unobstructed } \\
\text { urine flow, keep } \\
\text { bag below the } \\
\text { level of bladder at } \\
\text { all times. } \\
\text { *Empty the } \\
\text { collecting bag } \\
\text { regularly, } \\
\text { cleaning of the } \\
\text { meatal area. }\end{array}$ \\
\hline
\end{tabular}




\section{Appendix C}

\section{Project Schedule}

\begin{tabular}{|c|c|c|c|c|c|c|c|c|c|c|c|c|c|c|c|c|c|c|c|c|c|c|c|c|}
\hline & & 2780 & & & & & & & & R78 & & & & & & & & 7803 & & & & & & \\
\hline 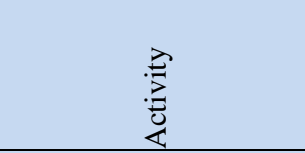 & $\begin{array}{l}\bar{y} \\
\frac{\pi}{8} \\
3\end{array}$ & $\begin{array}{l}m \\
\frac{1}{8} \\
3 \\
3\end{array}$ & $\begin{array}{l}n \\
\frac{n}{8} \\
3\end{array}$ & $\frac{5}{\frac{1}{3}}$ & $\frac{a}{3}$ & $\begin{array}{l}= \\
\frac{y}{8} \\
3\end{array}$ & $\begin{array}{l}\frac{m}{4} \\
\frac{\pi}{d} \\
\frac{d}{3}\end{array}$ & $\begin{array}{l}\frac{n}{3} \\
\frac{\pi}{8} \\
3\end{array}$ & $\frac{\bar{y}}{\frac{\pi}{8}}$ & $\begin{array}{l}m \\
\frac{4}{8} \\
3\end{array}$ & $\begin{array}{l}n \\
y \\
y \\
3\end{array}$ & $\begin{array}{l}\frac{1}{3} \\
\frac{4}{3} \\
3\end{array}$ & $\begin{array}{l}a \\
y \\
\vec{u} \\
3\end{array}$ & $\begin{array}{l}= \\
\frac{y}{8} \\
z\end{array}$ & $\begin{array}{l}\frac{m}{2} \\
\frac{\pi}{8} \\
3\end{array}$ & $\begin{array}{l}n \\
\frac{n}{d} \\
3\end{array}$ & $\begin{array}{l}\bar{y} \\
\frac{\pi}{3}\end{array}$ & $\begin{array}{l}m \\
\frac{n}{3} \\
3\end{array}$ & $\begin{array}{l}n \\
\ddot{y} \\
z \\
3\end{array}$ & $\begin{array}{l}5 \\
y \\
z \\
3\end{array}$ & $\begin{array}{l}a \\
\frac{y}{0} \\
3\end{array}$ & $\begin{array}{l}= \\
\frac{y}{8} \\
3\end{array}$ & $\begin{array}{l}\frac{m}{2} \\
\frac{y}{8} \\
3\end{array}$ & $\begin{array}{l}\frac{n}{4} \\
\frac{y}{8} \\
3\end{array}$ \\
\hline Meet with preceptor & $\mathrm{x}$ & $\mathrm{x}$ & $\mathrm{x}$ & $\mathrm{x}$ & $\mathrm{x}$ & $\mathrm{x}$ & $\mathrm{x}$ & $\mathrm{x}$ & $\mathrm{x}$ & $\mathrm{x}$ & $\mathrm{x}$ & $\mathrm{x}$ & $\mathrm{x}$ & $\mathrm{x}$ & $\mathrm{x}$ & $\mathrm{x}$ & $\mathrm{x}$ & $\mathrm{x}$ & $\mathrm{x}$ & $\mathrm{x}$ & $\mathrm{x}$ & $\mathrm{x}$ & $\mathrm{x}$ & $\mathrm{x}$ \\
\hline $\begin{array}{l}\text { Review of data of } \\
\text { CAUTI rates \& } \\
\text { Review current } \\
\text { protocol }\end{array}$ & $\mathrm{x}$ & $\mathrm{x}$ & & & & & & & & & & & & & & & & & & & & & & \\
\hline Team collaboration & & & & & & & & & $\mathrm{x}$ & & & & & & & & & & & & & & & \\
\hline $\begin{array}{l}\text { Prepare project } \\
\text { proposal }\end{array}$ & & & & & & & & & $\mathrm{x}$ & & & & & & & & & & & & & & & \\
\hline $\begin{array}{l}\text { Review the } \\
\text { requirements of the } \\
\text { IRB process }\end{array}$ & & & & & & & & & $\mathrm{x}$ & & & & & & & & & & & & & & & \\
\hline $\begin{array}{l}\text { Review documents } \\
\text { before sending to IRB }\end{array}$ & & & & & & & & & $\mathrm{x}$ & & & & & & & & & & & & & & & \\
\hline $\begin{array}{l}\text { IRB submission to } \\
\text { USA }\end{array}$ & & & & & & & & & $\mathrm{x}$ & & & & & & & & & & & & & & & \\
\hline IRB to DHR & & & & & & & & & & $\mathrm{x}$ & & & & & & & & & & & & & & \\
\hline $\begin{array}{l}\text { IRB review from USA } \\
\text { and DHR }\end{array}$ & & & & & & & & & & & $\mathrm{x}$ & & & & & & & & & & & & & \\
\hline $\begin{array}{l}\text { IRB from USA and } \\
\text { DHR approve project }\end{array}$ & & & & & & & & & & & & $\mathrm{x}$ & & & & & & & & & & & & \\
\hline $\begin{array}{l}\text { Develop an } \\
\text { Interdisciplinary team }\end{array}$ & & & & & & & & & & & & $\mathrm{x}$ & & & & & & & & & & & & \\
\hline $\begin{array}{l}\text { Initiate } \\
\text { Education/training for } \\
\text { all nurses in the } \\
\text { rehabilitation unit }\end{array}$ & & & & & & & & & & & & & $\mathrm{x}$ & & & & & & & & & & & \\
\hline $\begin{array}{l}\text { Evaluate results of } \\
\text { competency handout } \\
\text { pre/post training }\end{array}$ & & & & & & & & & & & & & $\mathrm{x}$ & & & & & & & & & & & \\
\hline $\begin{array}{l}\text { Implementation of } \\
\text { nurse-driven protocol } \\
\text { CAUTI bundle }\end{array}$ & & & & & & & & & & & & & $\mathrm{x}$ & & & & & & & & & & & \\
\hline
\end{tabular}




\begin{tabular}{|c|c|c|c|c|c|c|c|c|c|c|c|c|c|c|c|c|c|c|c|c|c|c|c|c|}
\hline & \multicolumn{8}{|c|}{ NUR7801 } & \multicolumn{8}{|c|}{ NUR7802 } & \multicolumn{8}{|c|}{ NUR7803 } \\
\hline 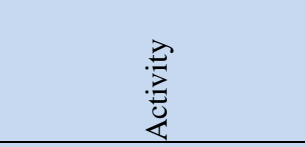 & $\frac{\bar{y}}{\bar{d}}$ & $\frac{m}{\frac{n}{d}}$ & $\begin{array}{l}n \\
\frac{4}{3} \\
3 \\
3\end{array}$ & $\frac{\pi}{3}$ & $\frac{a}{\frac{1}{d}}$ & $\begin{array}{l}= \\
\frac{y}{8} \\
3\end{array}$ & $\frac{m}{\frac{n}{d}}$ & $\begin{array}{l}\frac{n}{y} \\
\frac{y}{8} \\
3\end{array}$ & $\begin{array}{l}\bar{y} \\
\frac{y}{0} \\
3\end{array}$ & $\frac{m}{\frac{4}{8}}$ & $\begin{array}{l}n \\
\frac{y}{d} \\
3\end{array}$ & $\begin{array}{l}n \\
\frac{\pi}{u} \\
3\end{array}$ & $\begin{array}{l}a \\
\frac{u}{u} \\
3\end{array}$ & $\begin{array}{l}= \\
\frac{\pi}{8} \\
3\end{array}$ & $\frac{m}{\frac{n}{0}}$ & $\begin{array}{l}\frac{n}{4} \\
\frac{u}{d} \\
3\end{array}$ & $\frac{\bar{x}}{\bar{d}}$ & $\begin{array}{l}m \\
\frac{4}{d} \\
3\end{array}$ & $\begin{array}{l}n \\
\frac{x}{0} \\
3 \\
3\end{array}$ & $\frac{\pi}{3}$ & $\begin{array}{l}a \\
\frac{u}{0} \\
z\end{array}$ & $\begin{array}{l}= \\
\frac{x}{0} \\
3 \\
3\end{array}$ & $\begin{array}{l}\frac{m}{4} \\
\frac{u}{2} \\
3\end{array}$ & $\begin{array}{l}\frac{n}{4} \\
\frac{y}{8} \\
\frac{d}{3}\end{array}$ \\
\hline Audit with feedback & & & & & & & & & & & & & & $\mathrm{x}$ & $\mathrm{x}$ & $\mathrm{x}$ & & & & & & & & \\
\hline $\begin{array}{l}\text { Determine if further } \\
\text { training is required }\end{array}$ & & & & & & & & & & & & & & $\mathrm{x}$ & $\mathrm{x}$ & $\mathrm{x}$ & & & & & & & & \\
\hline $\begin{array}{l}\text { Ongoing data } \\
\text { collection on CUATI } \\
\text { bundle compliance }\end{array}$ & & & & & & & & & & & & & & $\mathrm{x}$ & $\mathrm{x}$ & $\mathrm{x}$ & $\mathrm{x}$ & $\mathrm{x}$ & & & & & & \\
\hline $\begin{array}{l}\text { Final Collection of } \\
\text { Data }\end{array}$ & & & & & & & & & & & & & & & & & & & $\mathrm{x}$ & & & & & \\
\hline $\begin{array}{l}\text { Data analysis using the } \\
\text { IBM SPSS system }\end{array}$ & & & & & & & & & & & & & & & & & & & $\mathrm{x}$ & $\mathrm{x}$ & & & & \\
\hline $\begin{array}{l}\text { Compare baseline data } \\
\text { to post implementation } \\
\text { of intervention }\end{array}$ & & & & & & & & & & & & & & & & & & & & $\mathrm{x}$ & $\mathrm{x}$ & & & \\
\hline Completion of project & & & & & & & & & & & & & & & & & & & & & & $\mathrm{x}$ & & \\
\hline & & & & & & & & & & & & & & & & & & & & & & & & \\
\hline & & & & & & & & & & & & & & & & & & & & & & & & \\
\hline & & & & & & & & & & & & & & & & & & & & & & & & \\
\hline & & & & & & & & & & & & & & & & & & & & & & & & \\
\hline & & & & & & & & & & & & & & & & & & & & & & & & \\
\hline
\end{tabular}




\section{Appendix D}

\section{CAUTI Bundle Audit}

\begin{tabular}{|l|l|l|}
\hline $\begin{array}{l}\text { Date: } \\
\text { Rehabilitation Unit }\end{array}$ & Reviewer & Patient Room Number \\
\hline $\begin{array}{l}\text { Total number of new CAUTI } \\
\text { events }\end{array}$ & & \\
\hline $\begin{array}{l}\text { Number of patients with } \\
\text { catheters }\end{array}$ & & \\
\hline $\begin{array}{l}\text { Number of catheter days (\# of } \\
\text { days the patient had the } \\
\text { catheter in place) }\end{array}$ & & \\
\hline Number of re-catheterizations & & \\
\hline $\begin{array}{l}\text { Total number of nurses who } \\
\text { completed the nurse-driven } \\
\text { protocol CAUTI bundle } \\
\text { compliance tool }\end{array}$ & & \\
\hline $\begin{array}{l}\text { The number of clinical staff } \\
\text { who completed education and } \\
\text { training }\end{array}$ & & \\
\hline Patient satisfaction, & & \\
\hline Staff satisfaction & & \\
\hline
\end{tabular}

Note. Adapted from the Institute for Healthcare Improvement, 2020.

http://www.ihi.org/resources/Pages/Tools/UTIBundleComplianceAuditTool.aspx 


\section{Appendix E}

\section{SWOT Analysis}

\begin{tabular}{|l|l|}
\hline Internal Forces & External Forces \\
\hline Strengths & Opportunities \\
\hline *Support from leadership & *Improve practice and quality of care. \\
*Support from rehabilitation director/nurse & *Collect data and see trends. \\
manager to implement intervention. & *More competent staff \\
*Education department available to provide & *Decrease CAUTIs in the facility \\
trainings in reference to intervention. & *Decrease IUC days \\
*Needed resources available for project. & *Potential decrease hospital days \\
*May decrease hospital costs & *Potential decrease cost for the facility \\
\hline Weakness & Threats \\
\hline *Probable resistance to change from frontline & *Staff turnover \\
staff. & *Newly hired nurses with little or no \\
*Short staff & experience \\
* Limited time to assist trainings & *Change in management. \\
& *Lack of support from physician \\
\hline
\end{tabular}




\section{Appendix F}

\section{Pre- and Post-Education/Training Tool}

For each of the following questions, CHECK the answer which best characterizes how you feel about the contribution of the risk factors to the development of a CAUTIs, where 1: Strongly Disagree, 2: Disagree, 3: Neither Agree Nor Disagree, 4: Agree, and 5:Strongly Agree

\begin{tabular}{|l|l|l|l|l|l|}
\hline & $\begin{array}{l}\text { 1. Strongly } \\
\text { Disagree }\end{array}$ & 2. Disagree & $\begin{array}{l}\text { 3. Neither } \\
\text { Agree nor } \\
\text { Disagree }\end{array}$ & 4. Agree & $\begin{array}{l}\text { 5. Strongly } \\
\text { Agree }\end{array}$ \\
\hline $\begin{array}{l}\text { 1 Appropriate } \\
\text { Indications }\end{array}$ & & & & & \\
\hline $\begin{array}{l}\text { 2Inappropriate } \\
\text { Indications }\end{array}$ & & & & & \\
\hline $\begin{array}{l}\text { 3 Length of } \\
\text { catheter days }\end{array}$ & & & & & \\
\hline $\begin{array}{l}\text { 4 Hand } \\
\text { hygiene }\end{array}$ & & & & & \\
\hline $\begin{array}{l}\text { 5 Aseptic } \\
\text { technique } \\
\text { during } \\
\text { insertion }\end{array}$ & & & & & \\
\hline $\begin{array}{l}\text { 6 Lack of } \\
\text { routine } \\
\text { hygiene of } \\
\text { periurethral } \\
\text { area }\end{array}$ & & & & & \\
\hline $\begin{array}{l}\text { 7 Breaking the } \\
\text { closed system }\end{array}$ & & & & & \\
\hline $\begin{array}{l}\text { 8 Foley bag } \\
\text { 2/3 full } \\
\text { emptied prior } \\
\text { to transport }\end{array}$ & & & & & \\
\hline $\begin{array}{l}\text { 9 Drainage } \\
\text { bag below } \\
\text { bladder }\end{array}$ & & & & & \\
\hline $\begin{array}{l}\text { 10 Drainage } \\
\text { bad does not } \\
\text { touch the floor }\end{array}$ & & & & & \\
\hline
\end{tabular}

Note. Adopted from the Agency for Healthcare Research and Quality (2018).

https://www.ahrq.gov/hai/hac/tools.html 


\section{Appendix G}

\section{Staff Survey}

Please answer the following questions on a 5-point scale: 1 = Strongly Disagree; 2 = Disagree; 3 = Neither $; 4$ = Agree; 5 = Strongly Agree

1. The hospital's current catheter associated urinary tract infection protocol is easy for nurses to utilize.

\section{5}

2. I was adequately educated on the hospital's current catheter associated urinary tract infection protocol.

12345

3. I provide catheter care to all patients with indwelling urinary catheters in my care every shift

\section{5}

4. Discontinuing indwelling urinary catheters when no longer indicated is one of my daily priorities

12345

5. Renal failure is an indication for an indwelling urinary catheter.

12345

6. There is no need for handwashing prior to indwelling urinary catheter care as this is not a sterile procedure.

12345

7. Acute urinary retention is an indication for an indwelling urinary catheter.

\section{5}

8. A family's request is a good reason to utilize an indwelling urinary catheter.

12345

62

9. Nurses are key players in the reduction of indwelling urinary catheter use in hospitals.

12345

10. During handoff indwelling urinary catheters are routinely addressed. 12345

Note. Adapted from the Agency for Healthcare Research and Quality (2018).

https://www.ahrq.gov/hai/hac/tools.html 


\section{Appendix H}

\section{CAUTI Bundle-Compliance Tool}

\begin{tabular}{|c|c|c|c|}
\hline \multicolumn{4}{|l|}{$\begin{array}{l}\text { Date: } \\
\text { Department: } \\
\text { Inserted by: } \\
\text { Reviewer: }\end{array}$} \\
\hline $\begin{array}{l}\text { Is this catheter for a clinically appropriate reason? } \\
\text { (check one) } \\
\text { Obstruction of the urinary tract distal to the bladder } \\
\text { volume measure. } \\
\text { Alteration in BP or volume status requiring accurate } \\
\text { procedure. } \\
\text { Preop catheter insertion for patient going to OR } \\
\text { hemorrhage/ TURP } \\
\text { stage } 3-4 \text { perineal ulcer } \\
\text { retention } \\
\text { Courogenic bladder dysfunction and urinary } \\
\text { Comfort Care. } \\
\text { Other: }\end{array}$ & & & \\
\hline $\begin{array}{l}\text { Physician notified if above not checked, for D/C } \\
\text { order? }\end{array}$ & & & \\
\hline WASH HANDS and wear gloves when handling catheter & & & \\
\hline PERICARE done routinely? & & & \\
\hline $\begin{array}{l}\text { Catheter Securement Device maintained and in } \\
\text { comfortable position? }\end{array}$ & & & \\
\hline Catheter bag <2/3 full and emptied prior to transport? & & & \\
\hline $\begin{array}{l}\text { CLOSED SYSTEM maintained seal intact at junction of } \\
\text { tubing/catheter }\end{array}$ & & & \\
\hline $\begin{array}{l}\text { Drainage BAG attached to side of bed and BELOW the } \\
\text { level of the BLADDER? }\end{array}$ & & & \\
\hline $\begin{array}{l}\text { Drainage BAG and tubing DO NOT TOUCH the } \\
\text { FLOOR? }\end{array}$ & & & \\
\hline Documentation in Cerner (insertion, date, etc.) & & & \\
\hline
\end{tabular}

Note. Adapted from the Institute for Healthcare Improvement, 2020.

http://www.ihi.org/resources/Pages/Tools/UTIBundleComplianceAuditTool.aspx 


\section{Appendix I}

Variables Table

\begin{tabular}{|l|l|l|}
\hline Variables & Type of Data & Statistical Test \\
\hline CAUTI Rate & Continuous & $\begin{array}{l}\text { Mean, Standard Unpaired t- } \\
\text { test }\end{array}$ \\
\hline CAUTIs (\# of new events) & Continuous & $\begin{array}{l}\text { Mean, Standard Unpaired t- } \\
\text { test }\end{array}$ \\
\hline Number of re-catheterizations & Continuous & $\begin{array}{l}\text { Mean, Standard Unpaired t- } \\
\text { test }\end{array}$ \\
\hline $\begin{array}{l}\text { Nurse Compliance to the } \\
\text { CAUTI Bundle }\end{array}$ & Nominal & Frequency, Percentage \\
\hline $\begin{array}{l}\text { Number of clinical staff who } \\
\text { completed education/training }\end{array}$ & Nominal & Frequency, Percentage \\
\hline
\end{tabular}

